\title{
Homicídios no MUNICÍPIO de SÃo PAULO: PERFIL E SUBSÍDIOS PARA UM SISTEMA DE VIGILÂNCIA EPIDEMIOLÓGICA
}

\author{
Vilma Pinheiro Gawryszewski
}

\begin{abstract}
Tese apresentada na área de concentração de Epidemiologia da Faculdade de Saúde Pública da Universidade de São Paulo, para obtenção do Grau de Doutor
\end{abstract}

Orientação: Prof. Dra. Maria Helena Prado de Mello Jorge 
Autorizo, exclusivamente para fins acadêmicos e científicos, a reprodução total ou parcial desta tese, por processos fotocopiadores. 


\section{Sinceros agradecimentos:}

À Prof. Dra. Maria Helena Prado de Mello Jorge, pelos ensinamentos como orientadora e expressando minha grande admiração por todo o seu trabalho.

Programa de Aprimoramento das Informações de Mortalidade, pelo acesso ágil aos dados:

Dr. Mauro Tomoyuki Taniguchi e demais técnicos

Instituto Médico Legal pelo acesso aos dados e apoio:

Dr. Carlos A berto Coelho, Diretor do Instituto Médico Legal

Alex e demais funcionários

Secretaria de Segurança Pública, pelo acesso aos dados e discussões:

Dr. Marcó Antónió Desgualdo, Delegado Geral da Polícia Civil do Estado de São Paulo

Dra. Ana Sofia Schimidt de Oliveira, Coordenadora da Secretaria de Segurança Pública

Dra. Eliana B. T. Bordini, do CAP

Dr. Domingos de Paula Neto, Diretor do DHPP

Dr. Nivaldo-Pereira de Oliveira e demais profissionais do DHPP

Aos professores membros da comissão julgadora, pelas correções e ensinamentos preciosos:

Profa. Dra. Edinilsa Ramos de Souza

Prof. Dr. Elisew Alves Waldman

Prof. Dr. João Yunes

Profa. Marilisa Bertu de Azevedo Barros

Aos amigos e professores do Departamento de Epidemiologia da Faculdade de Saúde Pública - USP:

Profa. Dra. Denise Pimentel Bergamaschi

Elisabete Margarida Nassar Rúbeiro

Fernão Dias de Lima

Prof. Dr. José Maria Pacheco de Souza

Profa. Dra. Sabina Léa Davidson Gotlieb 
Aos amigos e professores da Secretaria de Saúde do Estado de São Paulo, por suas contribuições e carinho:

Prof. José da Rocha Carvalheiro, Coordenador dos Institutos de Pesquisa Aparecida Vieira de Melo

Márcía Aparecida Siqueira

Dra. NormaS. Farias

Vera Lúcía Lopes Osiano

Aos amigos da Escola de Enfermagem da USP pela:

Profa. Dra. Maria Sumie Koizumi

Alexandre AlmeidaGomes

E a todos os que apesar da sua importância e colaboração não foram citados 
Gawryszewski, VP. Homicidios no Municipio de São Paulo: perfil e subsidios para um Sistema de Vigilância Epidemiológica. São Paulo; 2002. [Tese de Doutoramento Departamento de Epidemiologia da Faculdade de Saúde Pública da USP]

\section{Resumo}

Introduçăo: As violências constituem-se hoje num importante problema de Saúde Pública, no Brasil e em vários países do mundo. Para o setor saúde, em razão da sua inerente complexidade, é um tema desafiador. Pela sua magnitude, constitui-se num problema urgente. Por isso, pensar no estabelecimento de vigilância epidemiológica torna-se tarefa inadiável.

Objetivos: Estudar o perfil de mortalidade por homicidios no Município de S. Paulo, com ênfase na integração de informações provindas de várias fontes e fornecer subsidios para uma proposta de vigilância epidemiológica.

Material e método: Dividido em três etapas: 1. Estudo do universo dos óbitos por homicidios ocorridos no Município de S. Paulo, no ano de 2000, a partir das Declaraçōes de Óbito (DO); 2. Integração das informaçōes constantes nas DO, Boletins de Ocorrência Policial (BO) e Laudos de Necrópsia, para os meses de abril a junho de 2000; 3. Análise das informações coletadas em inquéritos policiais encerrados, investigados na Delegacia de Homicídios e Proteção à Pessoa (DHPP).

Resultados: O coeficiente de mortalidade por homicídios, no ano de 2000 , foi $57,3 / 100.000$. O sexo masculino contribuiu com $92,5 \%$ do total e o sexo feminino com $7.5 \%$, com taxas de $111,1 / 100.000$ para os homens e $8,2 / 100.000$, para as mulheres. As idades de 15 a 29 anos concentraram $61,4 \%$ do total dessas mortes, exibindo também as maiores taxas. O coeficiente do sexo masculino na faixa de 20 a 24 anos chega a 286,4/100.000.

As armas de fogo responderam por $90,1 \%$ das mortes. $O$ álcool foi a substância psicoativa mais utilizada entre as vitimas que tiveram o exame toxicológico realizado no IML (positivo em $38,3 \%$ dos exames solicitados). Foi na via pública que ocorreu a maioria dos eventos $(68,8 \%)$, seguinda-se as residèncias $(9,9 \%)$. Os domingos e sábados são os dias com maior freqüência de atos violentos, especialmente nos horários notumos e madrugadas. A motivaçăo dos crimes foi identificada em $24,9 \%$ dos casos. Entre eles, a maior proporção $(29,6 \%)$ foi classificada como decorrente de conflitos interpessoais. Entre a motivação encontrada a partir do estudo dos 
inquéritos policiais encerrados os crimes relacionados ao uso e tráfico de drogas chegam a $41,0 \%$. Os conflitos respondem por $12,0 \%$.

Os dados apontam desigualdade na distribuiçăo espacial do risco para mortes por homicidios, com as maiores taxas sendo observadas nos distritos periféricos, com indicadores sócio-económicos desfavoráveis. O Jardim Paulista obteve o menor coeficiente de mortalidade por homicidios (3,6/100.000). No extremo oposto encontra-se o distrito de Parelheiros, com coeficiente quase trinta vezes 0 do primeiro, atingindo $106,3 / 100.000$.

No estudo do perfil das vítimas, a partir dos inquéritos encerrados, investigados no DHPP, observa-se que a maioria das vitimas $(51,7 \%)$ encontrava-se desempregada na ocasião do óbito. Não completaram o ensino fundamental 40,1\%. O álcool era utilizado por $42,5 \%$, seguindo-se a maconha, com $22,1 \%$. No grupo dos agressores, comparativamente às vítimas, os percentuais são mais desfavoráveis quanto a escolaridade, situação de conflitos com a lei e uso de substâncias psicoativas.

Conclusóes: O modelo proposto para vigiláncia epidemiológica dos homicídios, um sistema ativo que integra informaçōes das Declaraçōes de Óbito, Boletins de Ocorrência Policial e Laudo de Necropsia, ampliou o número de variáveis estudadas agregando maior qualidade, permitindo, portanto, conhecer melhor, as caracteristicas das vítimas e das circunståncias que cercaram os eventos. 
Gawryszewski, VP. Homicidios no Municipio de São Paulo: perfil e subsidios para um Sistema de Vigilância Epidemiológica. São Paulo; 2002. [Tese de Doutoramento Departamento de Epidemiologia da Faculdade de Saúde Pública da USP]

\section{Summary}

Context: The violence is an important problem of Public Health, in Brazil and in several countries of the world. It is a very complex problem, because this it is a challenging goal for public health. It is an urgent problem to solve. Despite the high number and homicide rates, there are not injuries surveillance systems, therefore it has become a pressing task.

Objectives: To characterize the mortality for homicides, identify risk factories, and to develop a proposal of active surveillance system, using some existing data sources.

Design: Cases were 5978 homicide victims in 2000 . To link data were used: 1 . deaths certificates, 2. police investigations registers and 3 . Registers at the Forensic Institute of Medicine.

Setting: S. Paulo city, the biggest city in Brazil

Results: The overall homicide rate was 57,3 per100.000. Among males it was 11,1 per100.000, among female was 8,2 per 100.000 .

The ages from 15 to 29 years accounted $61,4 \%$ of the total of those deaths, especially the ages 20 to 24 years. For males aged 20 to 24 years the homicide rate was 286,4 per 100.000 .

Firearms responded to $90,1 \%$ of all deaths. This percentile increases a little among the youths. The alcohol was the substance more used among the victims, that had the toxicological exam accomplished in Forensic Institute of Medicine. This percentile was $38,3 \%$, and the use was different in relation to gender, firearms and place.

Most of this events occurred on public streets $(68,8 \%)$ and residences $(9,9 \%)$. Sundays and Saturdays, especially at night, were the days that most of these deaths occurred. These are schedules dedicated to the leisure, mainly youths.

The motivation of the crimes was identified in $24,9 \%$ of those deaths. The results pointed the deep inequality in the space distribution of the risk for deaths for homicides, with the largest rates being observed in the poor districts that presents more unfavorable socioeconomic indicators. 
It was identified 94 offenders, and it was compared some characteristics between them and victims. Both of them were unemployed in the moment of the event $(51,7 \%$ for victims and $51,1 \%$ for offenders) and they have low education.

About the use of alcohol and drugs: $42,5 \%$ used to use alcohol. The marijuana was the second drug more used, $22,1 \%$. About the authors' group, this group presented percentile worst about education level, law conflict and use of alcohol and drugs.

Conclusion: The model proposed for epidemic surveillance of the homicides, an active system that integrates information of the certifications of death, police investigation registers and registers of Forensic Institute of Medicine, enlarged the number of studied variables joining larger quality. 


\section{Sumário}

1. Introdução 1

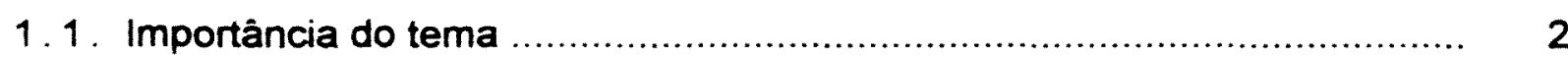

- Os dados estatisticos ................................................................... 2

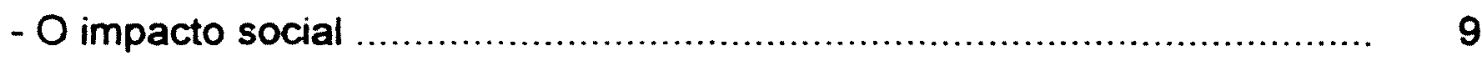

- Refletindo sobre a violência........................................................... 12

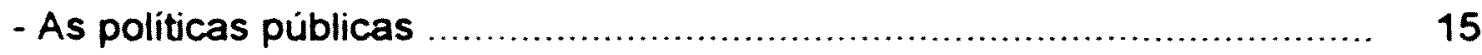

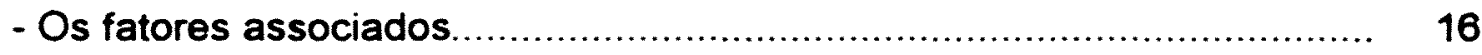

- Prevenção e violências.............................................................. 17

1.2. Vigilância Epidemiológica das Violèncias: um novo desafio ................... 19

- Por que estudar a mortalidade? ................................................... 21

- Uma proposta para a Vigilância Epidemiológica dos Homicidios............. 23

- Conceitos .................................................................................... 24

1.3. A presente proposta ..................................................................... 26

2. Objetivos 28

3. Material e Método 30

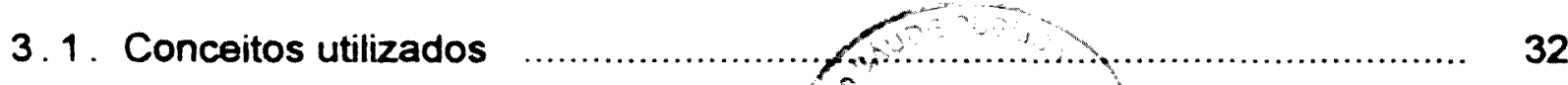

3.2. Fontes de informação ............................................................ 33

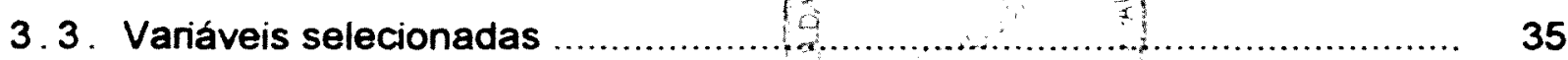

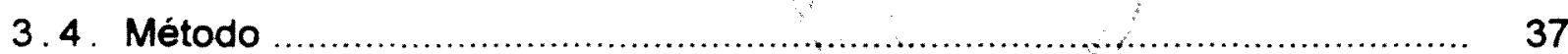

4. Resultados e discussão 39

4. 1. Perfil das vitimas ....................................................................... 42

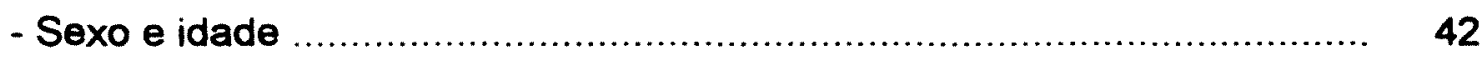

- Os homicidios segundo meio utilizado ........................................... 47

- Uso de substancias psicoativas ........................................................ 53

- Localização anatômica das lesões...................................................... 60

4.2. As circunstâncias do ato violento ................................................... 62

- Tipo de local onde ocorreu o evento ................................................ 62

- Dias da semana e horário da ocorrência................................................. 66

- Local em que ocorreu o óbito ........................................................... $\quad 70$

- A questão da motivação .................................................................. 73

4 . 3. A distribuição espacial das mortes por homicidios .................................. 77 
- Os homicidios segundo local de residència ................................. 77

- Os homicidios segundo local de ocorrência: retratando a guerra urbana 83

4.4. Informaçōes obtidas a partir dos inquéritos policiais ........................... 100

- Em relação ao uso e tráfico de substáncias psicoativas ..................... 104

- Alguns aspectos acerca do perfil dos agressores........................... 109

4.5. Subsidios do estudo para uma proposta de Vigilância Epidemiológica dos Homicídios

- Por que integrar dados? ...................................................... 114

- Inquéritos versus vigilância epidemiológica.................................... 115

- Os aspectos operacionais do sistema......................................... 116

- As variáveis selecionadas segundo as diferentes fontes de dados ....... 121

- Avaliação do sistema ................................................................. 122

- O pareamento dos casos ................................................... 125

- Outras experiências de vigilância ............................................... 126

4.5 Fatores associados e estratégias de intervenção .............................. 128

- Fatores de risco identificados em nosso meio ................................ 135

- Algumas experièncias de intervenção ........................................... 136

5. Consideraçőes finais 143

6. Conclusőes 148

$\begin{array}{ll}\text { 7. Referências } & 154\end{array}$ 


\section{Lista de Tabelas}

Tabela 1 Óbitos por causas externas, segundo sexo e tipo de acidente $\left(n^{\circ}, \%\right.$ e coeficientes $/ 100.000$ habitantes). Municipio de São Paulo, 2000.

Tabela 2 Homicidios segundo sexo e idade $\left(n^{\circ}, \%\right.$ e coeficientes $/ 100.000$ habitantes). Municipio de Săo Paulo, 2000.

Tabela 3 Homicidios no sexo masculino, idades de 15 a 24 anos 46 (coef/100.000). Paises das Américas

Tabela 4 Homicidios segundo sexo e meio utilizado. Municipio de São Paulo, 2000.

Tabela 5 Homicídios segundo meio utilizado (número e percentual) nas várias fontes. Município de São Paulo, abril a junho de 2000.

Tabela 6 Uso de substância psicoativas em vitimas de homicidios $\left(n^{\circ} \mathrm{e}\right.$ \%). Municipio de São Paulo, abril a junho de 2000.

Tabela 7 Homicídios segundo tipo de local em que ocorreu o evento $\left(n^{\circ} \mathrm{e}\right.$ \%). Municipio de Sáo Paulo, abril a junho de 2000.

Tabela 8 Homicidios segundo horário da ocorrência $\left(n^{\circ}\right.$ e \%). Municipio de São Paulo, abril a junho de 2000.

Tabela 9 Homicidios segundo os dias da semana de ocorrência ( $n^{\circ}$ e \%). Município de São Paulo, abril a junho de 2000.

Tabela 10 Distribuição dos homicidios segundo local de ocorrência do óbito $\left(n^{\circ} \in \%\right)$. Municipio de São Paulo, 2000.

Tabela 11 Homicidios segundo possibilidade de socorro médico ( $n^{\circ}$ e \%). Municipio de São Paulo, abril a junho de 2000.

Tabela 12 Distribuição dos homicidios segundo motivação $\left(n^{\circ}\right.$ e \%). Municipio de São Paulo, abril, maio e junho de 2000.

Tabela 13 Distribuição dos homicidios(número, \% e coeficiente/100.000) segundo local de residência. Municipio de São Paulo, 2000.

Tabela 14 Distribuição dos homicídios segundo local de residência e local de ocorrência (coeficiente/100.000). Municipio de São Paulo, abril a junho de 2000 .

Tabela 15 Vitimas de homicidios segundo estado civil ( $n^{\circ}$ e \%). Município de S. Paulo, 2000.

Tabela 16 Vitimas de homicidios segundo situação de emprego ( $n^{\circ}$ e \%). Municipio de S. Paulo, 2000.

Tabela 17 Vítimas de homicidios, segundo escolaridade da vítima ( $n^{\circ} \mathrm{e} \%$ ). Município de S. Paulo, 2000.

Tabela 18 Vitimas de homicidios, segundo uso de substâncias psicoativas ( $n^{\circ}$ e \%). Municipio de S. Paulo, 2000.

Tabela 19 Vitimas de homicidios, segundo tipo de subståncias psicoativas $\left(n^{\circ} \in \%\right)$.

Município de S. Paulo, 2000.

Tabela 20 Vitimas de homicidios segundo situação de conflito com a lei ( $n^{\circ}$ e \%). Município de S. Paulo, 2000.

Tabela 21 Vítimas de homicidios segundo motivo do evento ( $n^{\circ}$ e \%). 108 Município de S. Paulo, 2000. 


\section{Lista de Figuras}

Figura 1 Mortalidade por causas extemas (coeficientes/100.000).

Brasil e Estado de S. Paulo, 1980 -1999.

Figura 2 Mortalidade por causas externas. Municipio de São Paulo, 1960 $-1999$.

Figura 3 Distribuição das mortes por causas externas segundo tipos (\%).

06 Município de São Paulo, 2000.

Figura 4 Coeficientes de mortalidade por causas extemas, segundo tipo. Municipio de S. Paulo, 1960 - 99.

Figura 5 Material do estudo, homicídios segundo fontes, Município de Såo Paulo, 2000.

Figura 6 Coeficientes por homicidios segundo sexo e idade. Município de Sảo Paulo, 2000.

Figura 7 Coeficientes de mortalidade médio por causas extemas, homicidios, acidentes de transporte e suicidios, segundo faixas etárias. Município de S. Paulo, 1999-2000.

Figura 8 Distribuição temporal dos coeficientes de mortalidade por homicidios e percentual de utilizaçāo de arma de fogo. Municipio de S. Paulo, 60, 70, 80, 91 e 2000.

Figura 9 Homicidios segundo idade e meio utilizado. Municipio de São Paulo, abril, maio e junho, 2000.

Figura 10 Homicidios segundo a solicitação de exame e resultado positivo para álcool pela vitima segundo idades. Municipio de São Paulo, abril, maio e junho, 2000.

Figura 11 Homicidios segundo meio utilizado e uso de álcool. Município de S. Paulo, abril a junho de 2000.

Figura 12 Homicidios por armas de fogo, segundo localizaçāo anatômica da lesão. Municipio de S. Paulo, abril a junho de 2000.

Figura 13 Homicídios segundo tipo de local e utilização de arma de fogo (\%). Municipio de S. Paulo, 60, 70, 80, 91 e 2000.

Figura 14 Homicidios segundo dias e horário da semana de ocorrência. Municipio de São Paulo, abril a junho de 2000.

Figura 15 Mortalidade por homicidios segundo local de residência. Municipio de Sảo Paulo, 2000.

Figura 16 Mortalidade por homicidios segundo local de ocorrência. Municipio de Sāo Paulo, 2000.

Figura 17 Mortalidade por homicidios no sexo masculino, entre 15 e 29 anos de idade, segundo local de residência. Municipio de São Paulo, 1999/2000.

Figura 18 Taxa de mortalidade infantil por 1.000 nascidos vivos. Município de Sáo Paulo, 2000.

Figura 19 Mapa da exclusão/inclusão social. Municipio de São Paulo, 2000.

Figura 20 Renda média familiar em salários mínimos. Municipio de São Paulo, 1997

Figura 21 Curva ajustada para coeficiente de mortalidade por homicidios segundo local de residência (2000) e renda média (1997). Municipio de São Paulo

Figura 22 Vitimas de homicidios segundo faixa etária (\%) segundo diferentes fontes de dados. Municipio de S. Paulo, 2000. 
Figura 23 Vítimas e agressores segundo situação de emprego. Inquéritos encerrados no DHPP. Municipio de S. Paulo, 2000.

Figura 24 Vítimas e agressores segundo escolaridade. Inquéritos 112 encerrados no DHPP. Município de S. Paulo, 2000.

Figura 25 Vítimas e agressores segundo uso de substâncias psicoativas. 113 Inquéritos encerrados no DHPP. Municipio de S. Paulo, 2000.

Figura 26 Fluxo de informaçőes para 0 sistema de vigilância 120 epidemiológica de homicidios 
1. Introdução 


\subsection{Importância do tema}

Os acidentes e as violências (também chamados de causas externas) destacam-se hoje, em vários países do mundo, dentre os mais importantes problemas de Saúde Pública. No Brasil, torna-se particularmente grave em seus grandes centros urbanos, como o Rio de Janeiro, São Paulo, Recife e Vitória, entre outros, bem como para as suas regiões metropolitanas (Mello Jorge e col., 1997; Souza, 1994).

Em razão da sua complexidade, a violência é um tema desafiador. Mas, pela magnitude, constitui-se um problema urgente, tornando inadiáveis as iniciativas de todos os setores na busca de soluções. À área da saúde, por sua tradição na condução de pesquisas epidemiológicas bem sucedidas, que contribuiram para o estabelecimento de fatores associados com as doenças cardiacas, AIDS, entre outras, cabe implementar o desenvolvimento de estudos que possam auxiliar a compreensão do problema, bem como na definição de políticas e estratégias de ação.

\section{- Os dados estatistucos}

O estudo dos dados sobre a mortalidade violenta no Brasil revela que os valores dos coeficientes por causas externas apresentam-se em crescimento, o que pode ser verificado na Figura 1 (SES, 2000).

Cabe assinalar que tal crescimento coloca o Brasil em rota inversa da maioria dos paises das Américas, que vêm experimentando um decréscimo nesta taxas, conforme estudo realizado por Yunes \& Zubarev (1999), utilizando 
dados levantados a partir de 1980 até o último ano disponível da década de 90. Podem ser citados, como exemplos, o Canadá, cujo decréscimo foi de $28 \%$ (entre os anos de 1980 e 1995), os Estados Unidos da América, com 22\% (entre 1980 e 1997) e o México, 39\% (no período de 1990 a 1995).

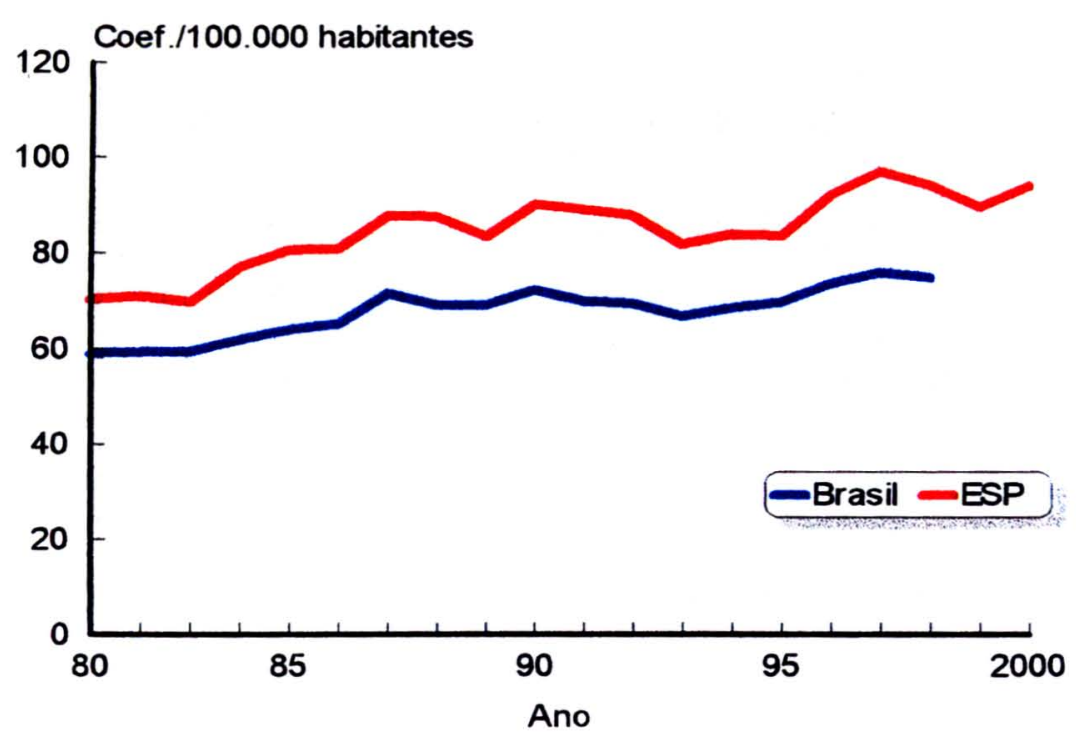

Fonte: DATASUS/MS e Fundação SEADE

Figura 1- Mortalidade por Causas Externas (coeficientes/100.000). Brasil e Estado de São Paulo, 1980 -1999.

Esses autores mostraram que, apesar dessas causas também se constituírem num sério problema para esses países, somente o Brasil e a Colômbia apresentaram aumento em suas taxas de mortalidade por causas externas. A população deste último país vive em um conturbado (e explícito) cenário político, econômico e social, desde a década de 60 , por problemas decorrentes de atividades de guerrilhas (com duas facções de esquerda), um grupo paramilitar (que combate a guerrilha de esquerda) e o crime organizado ligado ao narcotráfico. E a respeito do Brasil, que explicações poderiam ser levantadas? 
Em 1998, o grupo de causas externas equivaleu a $15 \%$ do total de mortes por causas definidas no Brasil (RIPSA, 2000), constituindo-se na segunda causa de morte para a população geral e a primeira para a faixa etária de 5 a 39 anos. O coeficiente de mortalidade, em 1997, atingiu $74,2 / 100.000$ habitantes, sendo que $34 \%$ desses óbitos foram devidos aos homicidios.

Para o Estado de São Paulo, as informações coletadas mostram que os acidentes e violências são um problema ainda mais grave: as taxas são mais altas, tendo alcançado 94,2/100.000 habitantes para o ano de 1999 (SES, 2000) (Figura 1). Além disso, o crescimento verificado no periodo (1980 a 1999) também foi maior do que o observado para a população brasileira como um todo: $33,9 \%$. Ainda nesse ano, as causas externas foram responsáveis por $15,3 \%$ do total de mortes por causas determinadas, representando a terceira causa de morte para a população geral. Cabe assinalar que as neoplasias, que ocuparam o segundo lugar, apresentaram taxas muito próximas: $96,2 / 100.0000$. Os óbitos devidos aos homicidios representaram $43 \%$ do total.

A análise das informações do Município de São Paulo mostra maior riqueza, visto que os dados vêm sendo coletados desde 1960, o que permitiu a construção de uma série histórica sobre mortalidade por causas externas e a obtenção de um retrato desse fenômeno nos últimos 40 anos (Mello Jorge, 1979 e 1982; Gawryszewski, 1995; Gawryszeski \& Mello Jorge, 2000). A Figura 2 possibilita verificar o acentuado crescimento desse grupo de causas: entre 1960 e 1999, o coeficiente de mortalidade por causas externas por cem mil habitantes passou de 44,1 para 86,7 (aumento de $96,6 \%$ ).

Nesta curva, identificam-se dois momentos importantes: o primeiro ocorrido entre 1965 e 1970, após o qual os coeficientes se estabilizam. E o segundo, após 1980, mantendo-se em crescimento a partir de então.

Com dados de 2000 (fornecidos pelo Programa de Aprimoramento das Informações de Mortalidade no Município de São Paulo, o PRO-AIM), verificase o peso desse agravo na mortalidade geral: $14,6 \%$ do total de óbitos por causa determinada em residentes no Município de São Paulo foram devidos às 
causas externas, ocupando o terceiro lugar entre as causas de morte na população geral. Cabe assinalar que este percentual encontra-se em ascensão ao longo das décadas, visto que, em 1960, representava apenas $6,5 \%$ do total de mortes.

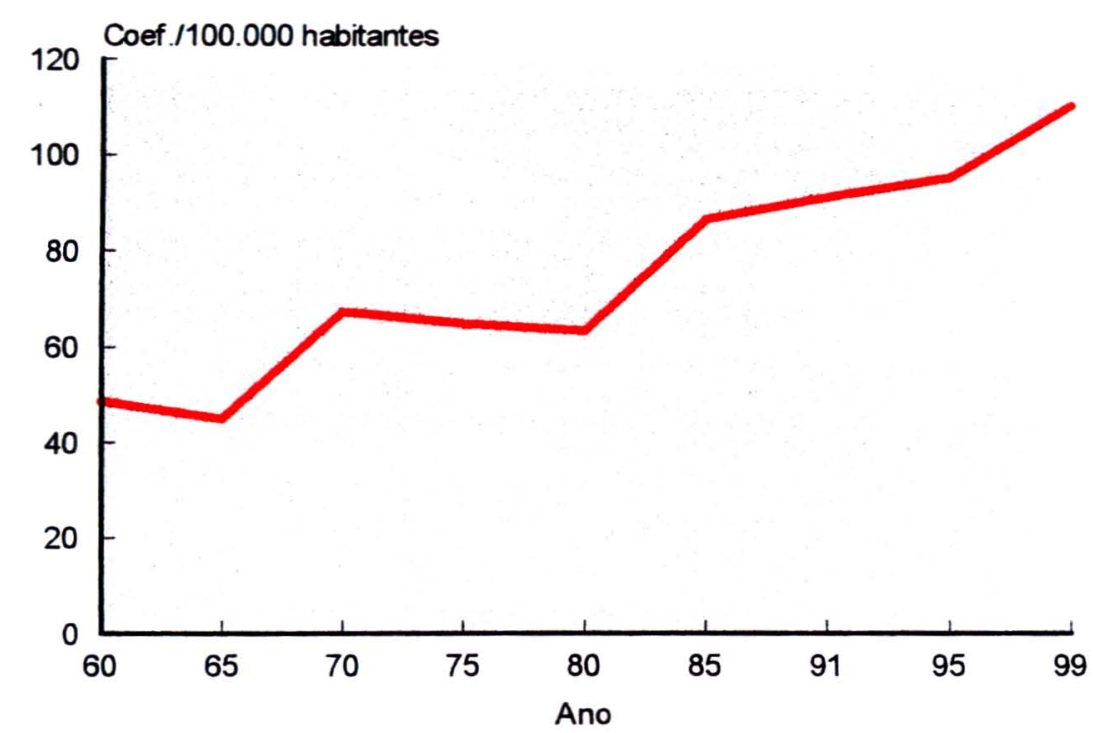

Fonte: Mello Jorge,1979, 1982; Gawryszewski, 1995;

Gawryszewski \& Mello Jorge, 2000

Figura 2: Mortalidade por causas externas.

Municipio de São Paulo, 1960 -1999.

No entanto, ao focalizar certos grupos especificos, a importância dessas mortes alcança ainda uma maior relevância. Este é o caso da população masculina, na qual o conjunto de causas violentas representa o segundo lugar entre o total de causas; e já constitui a primeira causa na ampla faixa etária que vai de 5 a 49 anos.

As chamadas causas externas abrangem uma grande diversidade de eventos, como as quedas acidentais, afogamentos, acidentes de trânsito e homicídios, entre outros, que têm determinações (e conseqüentemente 
medidas de controle) muito diferentes. Por isso, torna-se fundamental o estudo desse grupo de causas segundo o tipo de acidente ou violência que determinou o óbito.

A análise dos dados disponibilizados pelo PRO-AIM, para o ano de 2000, revela que, no Município de São Paulo, o peso das mortes por homicídios vem preponderando, sendo responsáveis por $65,2 \%$ do total das mortes por causas externas (é importante assinalar que, no ano de 1995, representava 52\%, o que já era considerada uma proporção elevada). A Figura 3 ilustra melhor essa importancia, pois apresenta os percentuais de cada tipo de acidente ou violência para o ano de 2000.

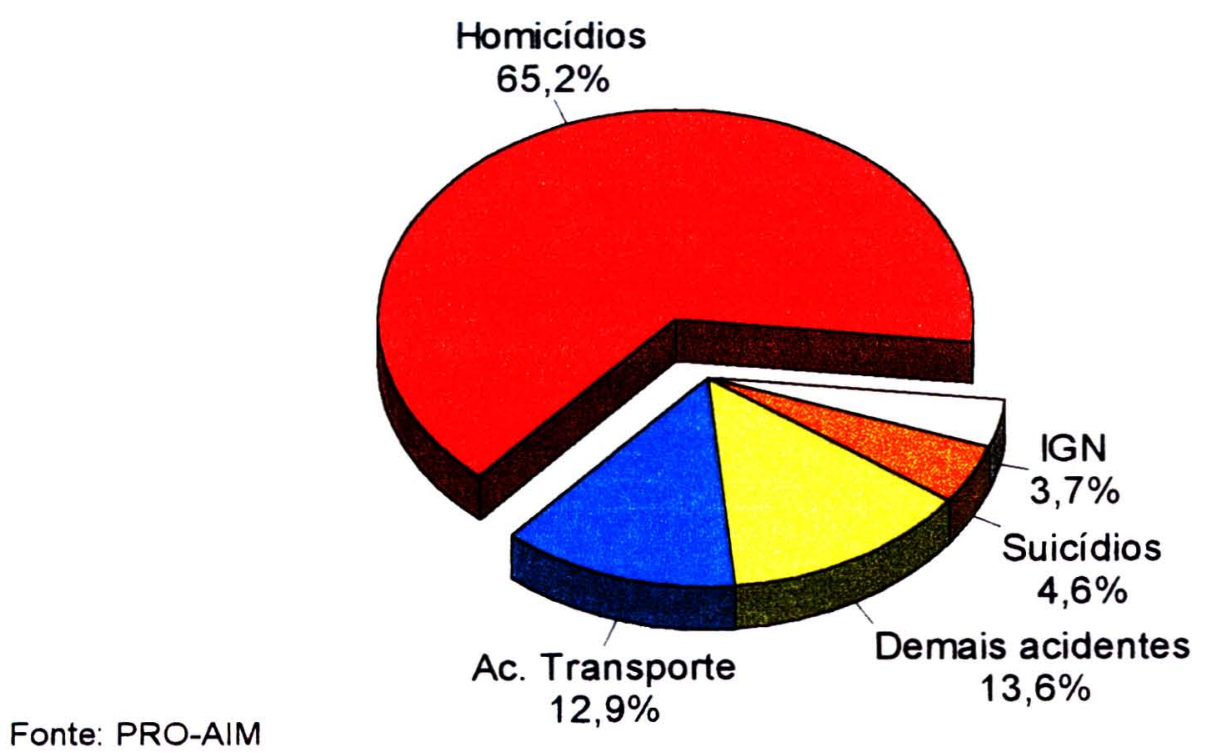

Figura 3 - Distribuição das mortes por causas externas segundo tipos (\%). Municipio de São Paulo, 2000.

Cabe ressaltar que os países considerados socioeconomicamente mais desenvolvidos, de um modo geral, têm sua estrutura de mortes violentas composta principalmente por componentes não intencionais, acidentes de trânsito e quedas, exatamente o oposto do observado para o Município de São 
Paulo. E, além disso, mesmo, entre os componentes intencionais, são os suicídios que lideram essa mortalidade nesses paises. Embora considerado um pais desenvolvido, os Estados Unidos da América apresentam mortalidade violenta alta e equilíbrio entre seus componentes intencionais, suicídios e homicídios (United Nations, 1999).

Mas, esse quadro verificado atualmente em nosso meio nem sempre foi assim. Em 1960, os homicidios ocupavam o quarto lugar na mortalidade por causas externas, e somente a partir da década de 80 , assumem o primeiro lugar (Figura 4). O primeiro período de aumento da mortalidade por causas externas (até a década de 70) deveu-se ao crescimento da mortalidade por acidentes de trânsito, provavelmente associado ao chamado milagre econômico, que se acompanhou da ampliação do parque industrial automobilístico no pais e aumento do número de rodovias. Isso possibilitou, a aquisição de automóveis por uma maior parcela da população e, por via de conseqüência, a ocorrência de maior número de mortes por essa causa. A partir do final da década de 70 , esses coeficientes foram declinando, fato que ocorreu nos países desenvolvidos uma década antes. Isso, provavelmente, foi conseqüente a um conjunto de fatores que englobaram desde as medidas desenvolvidas para redução de acidentes, como um aperfeiçoamento no desenho dos carros e rodovias, o aumento dos itens de segurança nos veículos, o aprimoramento das leis de trânsito existentes, educação da população, entre outros.

\section{Já o segundo periodo da curva vem revelar o grave problema dos} homicidios. Torna-se importante lembrar que a crise econômica brasileira teve seu início a partir da década de 80 , aumentando os índices de desemprego ${ }^{1}$, e estabelecendo, desde então, um novo ambiente econômico, no qual se acentuou ainda mais a concentração de renda já existente no país. Os coeficientes de mortalidade por homicídios, no período estudado, subiram de 5,18 para 53,0 (ambos por 100.000 habitantes), acumulando um

\footnotetext{
' Na década 70 o incremento da População Economicamente Ativa era próximo ao da população masculina. A partir dos anos 80 e 90 , assistiu-se a um descolamento destas duas dimensões, amplamente concentrado na população jovem (Bercovich e col, 1998).
} 
crescimento de $923,3 \%$, configurando uma verdadeira epidemia. É preciso, mais do que nunca, buscar os determinantes para essa situação. A Figura 4 mostra essa evolução.

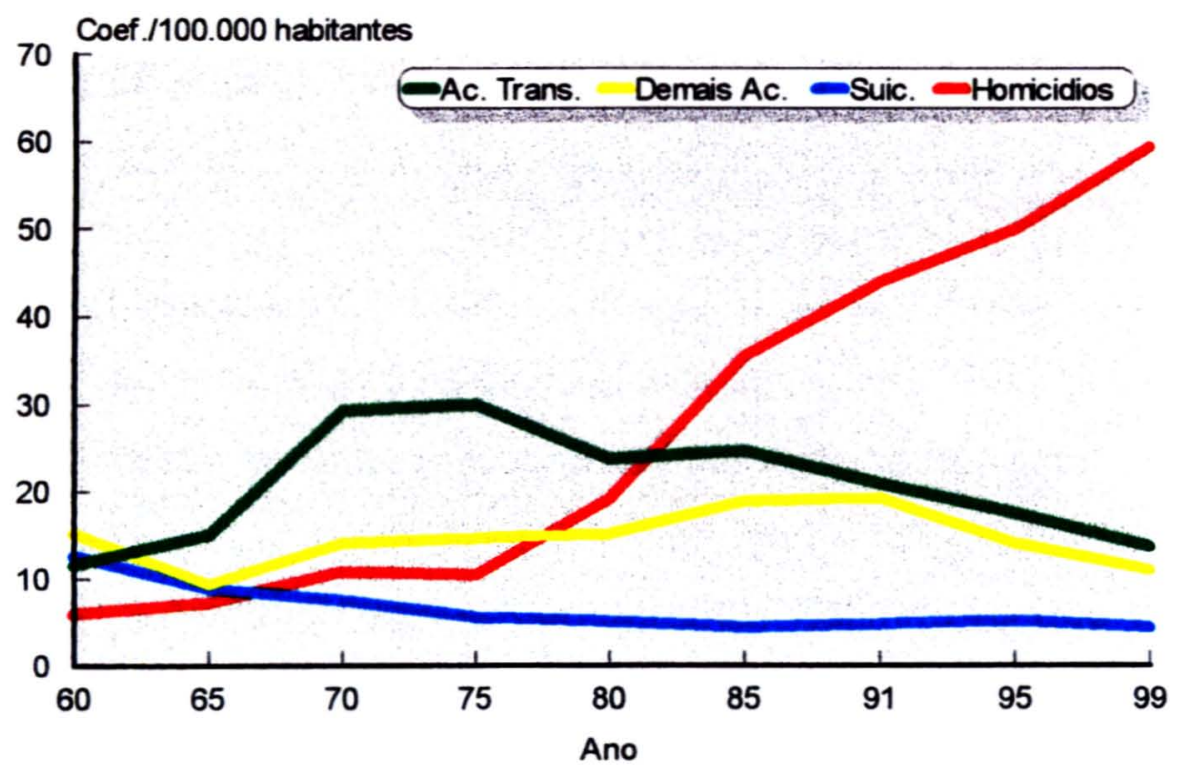

Fonte: Mello Jorge,1979, 1982; Gawryszewski, 1995;

Gawryszewski \& Mello Jorge, 2000

Figura 4 - Coeficientes de mortalidade por causas externas, segundo tipo. Municipio de S. Paulo, 1960 - 99.

Em relação às características das vitimas fatais de acidentes e violências, elas são principalmente do sexo masculino, e jovens. Tal achado é bastante comum, em se tratando de causas externas, tanto para outros países das Américas (Yunes, 1993; Yunes \& Zubarev, 1999), quanto para os dados de outros Estados do Brasil (Mello Jorge e col., 1997).

Os jovens hoje constituem uma das maiores preocupações de sociedades, governos e organismos internacionais. Pode ser citado como exemplo que a educação e os problemas relacionados aos jovens foi um dos temas da campanha eleitoral de Tony Blair, quando concorreu ao cargo de 
Primeiro Ministro na rica Inglaterra, em 19997 (Madeira \& Mameri, 1998). Do mesmo modo no Brasil, encontros, seminários e publicaçōes vêm sendo realizados para discutir especificamente as questões ligadas a esse grupo, como por exemplo, a publicação da Comissão Nacional de População e Desenvolvimento (CNPD, 1998), "Jovens acontecendo na trilha das políticas públicas".

Mas, para a sociedade brasileira, além dos problemas inerentes à juventude da atualidade, tem-se como agravante um fenômeno demográfico, denominado de "onda jovem" ${ }^{2}$. De acordo com a Fundação SEADE (Madeira \& Mameri, 1998; Bercovich e col., 1998), o Brasil, e especialmente o Estado de São Paulo, entraram no ano 2000 com uma das maiores proporções de jovens de 20 a 24 anos da sua história demográfica. Isso é resultante de um período de alta fecundidade no início dos anos 80 , seguida de uma queda brusca em 1983, gerando uma descontinuidade demográfica. Estimou-se que esta onda acarretou uma forte demanda pelo primeiro emprego entre 1996 e 2000, e demanda explosiva entre 2000 e 2005. Tal pressão demográfica, aliada à situação desfavorável no mercado de trabalho, estabelece um ambiente muito difícil para este jovem lidar e superar, especialmente aquele jovem pobre, com baixa escolaridade.

\section{- O impacto social}

Além dos dados estatísticos disponiveis, a experiência cotidiana da população vem demonstrando a importância do problema da violência, o que a mídia amplifica ainda mais. Assiste-se pela televisão, cada vez com maior freqüência, a cenas de disputas entre quadrilhas nas favelas do Rio de Janeiro, que utilizam armas de guerra com tiros de longo alcance, mostrando ousadia em relação às autoridades e a crescente sofisticação do armamento

\footnotetext{
Chama-se de onda o alargamento de uma determinada faixa etária.
} 
daqueles que desafiam as leis sociais; ou a exacerbação da violência entre adolescentes infratores por ocasião das mortes ocorridas na FEBEM do Municipio de São Paulo no segundo semestre de 1999, chamando atenção para a banalização da violência e para a perda de valores humanos básicos.

Os exemplos são muitos, e cada vez mais freqüentes, com repercussões negativas na midia internacional num mundo, hoje, globalizado. As terriveis cenas do seqüestro de um ônibus de linha regular da cidade do Rio de Janeiro, em outubro de 2000, com passageiros em seu interior, resultando nas mortes de uma refém e do seqüestrador, bem como a espantosa rebelião simultânea, organizada em vários estabelecimentos prisionais do Estado de São Paulo, em fevereiro de 2001, assustaram a população brasileira, tendo sido, inclusive, mostradas pela televisão em outros países. Como corolário dessa repercussão internacional, no final de 2001, um premiado velejador neozelandês é assassinado quando se encontrava em missão ecológica na Amazônia.

Para alguns economistas (Khan, 1999), tal fato tem impacto negativo sobre o turismo no país, pois, segundo cálculos feitos, o Brasil deixou de arrecadar 20 bilhões de dólares entre 1998 e 1999 nesta área. Uma vez que se estima que cada 1.000 dólares gastos por turista geram de dois a três empregos, o problema do desemprego no Brasil nas regiões turísticas seria praticamente reduzido a zero se esse fluxo de visitantes fosse mantido.

O impacto econômico dos acidentes e violência pode ser mostrado através da análise dos gastos hospitalares com internações realizadas pelo Sistema Único de Saúde, de acordo com os dados do Ministério da Saúde (MS, 2000) referentes ao ano de 1997, mostra que as internações por causas externas custaram aos cofres públicos $\mathrm{R} \$ 232.376 .613$ (8\% dos dispêndios com internações de todas as causas). Esses dados são reconhecidamente subestimados, não sendo contabilizados os atendimentos realizados nas emergências e hospitais particulares, além do que a tabela de cálculo utilizada é defasada em relação ao custo real. Mas, é importante assinalar que, quando se calcula o gasto/dia dessas hospitalizações, este é $60 \%$ superior à média 
dos gastos com as demais internações, ou seja, são eventos mais caros aos cofres públicos (lunes, 1997). Já o prejuízo em relação à qualidade de vida do cidadão é, literalmente, incalculável, não podendo ser medido em termos econômicos.

Poucos problemas sociais mobilizam tanto a opinião pública, atualmente, como a criminalidade e a violência. $E$ não é para menos. A sensação de angústia e medo vive dentro de todo cidadão, todos os dias, limitando seus passos, a sua liberdade, roubando uma parcela da sua vida. De uma maneira quase automática, sem que se perceba, algumas ruas são evitadas $^{3}$, visitas a parentes ou amigos não são mais realizadas, prefere-se não estudar se a escola oferece apenas o periodo noturno. Alarmes, traves, grades, cadeados e toda sorte de equipamentos são adquiridos. Para Khan (1999), o setor da vigilância privada é um dos únicos no país em que não existe crise. E a violência vem afetando a área da saúde também sob um outro aspecto: a Secretaria da Saúde da Prefeitura do Município de S. Paulo está encontrando dificuldades no preenchimento de vagas em postos e hospitais da periferia (APM, 2001), por causa da violência. Em função da violência, reordena-se parte das nossas vidas. Como medir esta quota diária de sofrimento?

Norbert Elias (1993) aponta que o Estado moderno tem um papel pacificador das relações sociais, coibindo os atos violentos por meio da elaboração de leis e regras de convivência; para isso, detém o monopólio da violência. Dois assassinatos, ocorridos no Estado de São Paulo, vem revelar a fragilidade do Estado, no momento atual: no final de 2001, o prefeito de Campinas, segundo maior municipio do Estado, é vítima de homicidio. Em janeiro de 2002, o prefeito do Município de Santo André é seqüestrado e morto barbaramente, fazendo com que o sentimento de medo, perplexidade e impotência aumente entre os cidadãos. A vulgarização do crime atinge agora também os representantes do Estado.

\footnotetext{
3 Pesquisa de vitimização do Ilanud (1998). realizada na capital do Estado de São Paulo. revelou que $45 \%$ dos habitantes costumam evitar certas nuas, locais ou pessoas por questões de segurança.
} 
Por isso, não soa nem um pouco estranho que uma pesquisa qualitativa realizada no Município do Rio de Janeiro, para o Relatório do Desenvolvimento Humano, desenvolvido pelo Ipea (Instituto de Pesquisa Econômica), acerca de qualidade de vida, tenha observado que a grande preocupação que unia todos os diferentes estratos sociais entrevistados era o temor de ser vitima de uma bala perdida ${ }^{4}$.

Como conseqüência de toda essa inquietação, perde-se progressivamente a capacidade de ser solidário e cordial com os demais cidadãos. Como seria possivel explicar o prejuizo nas relações sociais, quando um adulto reage com medo ao ser abordado por uma criança na rua? Que valores serão construídos por crianças criadas dentro do desprezo social? Essas são perdas intangiveis.

\section{- Refletindo sobre a violência}

A violência gera o medo, mas este gera igualmente a violência, num círculo vicioso. A taxa de homicídios no Brasil é comparável à da Inglaterra na Idade Média (Chesnais, 1999). As razões para esse extraordinário crescimento da violência no Brasil são dificeis de esclarecer, são vários os fatores em jogo.

As transformações recentes, a partir do final da década de 60 , são tão grandes que Wieviorka (1997) considera que há um novo paradigma da violência que caracteriza o mundo contemporâneo. Esse autor faz uma análise da violência bastante valiosa, cabendo por isso, ser reproduzida neste trabalho. Ela é feita a partir de quatro niveis: a do sistema internacional, a dos Estados, a das sociedades no interior dos Estados e, o quarto nivel, o do indivíduo. Este último, obedecendo a um fenômeno contemporâneo: o crescimento do individualismo.

\footnotetext{
${ }^{4}$ Jornal O Globo. de 29/05/2001.
} 
Conforme Wieviorka (1997), o sistema internacional (primeiro nível) foi afetado por duas mudanças com efeito considerável sobre a expressão da violência no mundo: a primeira delas, a Guerra Fria, que entre outros aspectos, trazia a ameaça velada de um conflito nuclear de grandes proporções e por isso possibilitava um controle parcial e desigual da violência, inibindo o aumento das violências ao extremo, não somente entre as duas superpotências, mas também em toda parte do mundo, pois um deslocamento do equilíbrio podia significar o risco de gerar uma escalada na tensão. A partir do seu fim, que se deu pelo esgotamento do regime soviético, vários conflitos internacionais têm surgido sendo que, em alguns deles, a violência atinge o barbarismo. A segunda mudança foi dada pela globalização da economia, a partir da metade dos anos 80 , que teve efeito sobre a difusão de bens culturais, determinando fraturas sociais e culturais, entre os paises incluidos e os excluídos. Nesse mundo fragmentado e globalizado aumentam as chances de graves violências localizadas serem deslocadas, exportadas, prolongadas para fora do seu espaço inicial.

O segundo nivel a ser analisado é o do Estado, aquele que detém o monopólio da violência física legítima. O fenômeno da mundialização trouxe um enfraquecimento do poder dos Estados, que se tornaram cada vez menos capazes de controlar suas economias, visto que encontram-se muito dependentes de recursos externos. Os fluxos, as decisões, os mercados, a circulação dos homens, dos capitais, das informações se dão em escala mundial, em parte, sob formas ilegais, o que leva o autor a falar acerca de uma globalização do crime organizado, especialmente no que concerne às drogas. Segundo o autor, um Estado enfraquecido é obrigado a recuar frente às atividades informais, ao trabalho clandestino, o recolhimento de recursos fiscais torna-se difícil de executar (recentemente no Brasil, o Governo Federal elaborou uma lei para diminuir as garantias trabalhistas). O Estado contemporâneo encontra-se, assim, atravessado por fora e por dentro. Aliado a isso, a fragmentação cultural enfraquece o sentido de Estado-Nação, visto que torna frágil a identidade cultural. 
No nível das sociedades, as transformações no modelo de desenvolvimento econômico, ligadas principalmente à perda da centralidade da indústria clássica, caminharam com fenômenos de desemprego, enfraquecimento do sindicalismo e crise social. Estas ligaçōes não são automáticas mas, por certo, encontram-se por trás da violência, construindo o cenário de injustiça, discriminação cultural, racial e social, que alimenta as frustrações.

O individualismo (quarto nível), um forte traço do mundo contemporâneo, apresenta-se sob duas faces. Se por um lado o indivíduo quer participar da modernidade, do que ela oferece, do que é mostrado nos meios de comunicação, enfim, fazer parte do espetáculo, hoje, globalizado do consumo, por outro lado também quer ser reconhecido como sujeito, construir sua própria existência. "Ele pretende, por exemplo, efetuar escolhas que o autorizem a referir-se a uma identidade coletiva, sem estar totalmente subordinado a ela, produzir-se, e não somente reproduzir-se" (Wieviorka, 1997). Cada uma dessas escolhas mantém uma relação muito forte com a violência. Aquela do indivíduo que se engaja no crime para conseguir dinheiro e consumir. Mas, também aquela produzida pelo sentimento de injustiça vivida, pela interdição do indivíduo de virar sujeito, que pode gerar o racismo, os motins, as gangues. Porém, nem toda expressão da violência individual é instrumental, existindo também aquela gratuita, lúdica, eventualmente ligada ao gosto pelo risco e desejo de aventura.

Nesse contexto, a violência vem preencher o vazio deixado pelo enfraquecimento das politicas e das relações sociais, tendo a ver com mudanças que afetam cada um dos quatro níveis, o sistema internacional, os Estados, as sociedades e o indivíduo, mas também o seu conjunto.

A imensa frustração social que pode ser sublimada em convicções e expressões religiosas, nacionais ou étnicas, pode também levar à violência. $O$ autor alerta, para o fato de que a privatização crescente da economia constitui encorajamento massivo à privatização da violência, visto que aos protagonistas da violència também interessa manter o Estado à distância das 
suas atividades ilícitas. Ligada ao controle e à acumulação de recursos econômicos, a violência não é necessariamente a arma dos pobres.

\section{- As politicas públicas}

O tema é tão atual que se tornou, nos últimos tempos, preocupação do Governo Federal. No segundo semestre do ano 2000 , foi anunciado um inédito Plano Nacional de Segurança Pública, envolvendo quatro Ministérios de Governo. Os pontos constantes desse Plano vão desde a liberação de recursos para reforçar as polícias Federais e Estaduais, criação de mais vagas nas penitenciárias, até propostas de projetos para a Reforma do Código Penal. Cria-se um fundo para financiar ações de segurança nos Estados, atrelado à redução da criminalidade.

Também há Projetos de Leis para a restrição de porte e compra de armas que vêm sendo discutidos no Poder Legislativo, nos niveis estadual e federal, sendo que um deles encontra-se em tramitação no Congresso Nacional.

No que diz respeito à área da saúde, recentemente, a Secretaria de Políticas de Saúde do Ministério de Saúde editou Informe Técnico para o estabelecimento de uma Política Nacional de Redução da Morbimortalidade por Acidentes e Violências, no qual é reiterado, em seus princípios básicos, que a saúde é um direito humano fundamental e essencial para o desenvolvimento social e econômico e que a promoção da saúde deve embasar todos os planos, programas, projetos e atividades de redução da violência e dos acidentes (MS, 2000). Esse conjunto de diretrizes foi aprovado pelo Conselho Nacional de Saúde e publicado no Diário Oficial da União de 18/05/2001 (Brasil, 2001), que recomenda "à elevação do tratamento desta questão ao primeiro nivel de prioridade das Politicas Públicas e de Saúde". 
Por este conjunto de razões, expressado por meio das estatísticas de mortalidade e da preocupação que os mais variados setores da sociedade vêm manifestando, quando se buscou priorizar, entre os diferentes tipos de causa externa aquele que deveria merecer um estudo mais aprofundado, a despeito da imensa complexidade e dificuldades inerentes ao próprio tema, a escolha do problema dos homicídios se fez inevitável.

\section{- Os fatores associados}

Considerando que a violência é reconhecidamente um fenômeno multicausal, torna-se importante identificar os vários fatores de risco ou fatores associados que contribuem para estas ocorrências, e dentre estes, aqueles passíveis de medidas de intervenção.

Em razão da relativa facilidade com que os dados de mortalidade atualmente são disponibilizados, muitos trabalhos já foram realizados em nosso meio, identificando-se os grupos de risco (homem, jovem, morador das áreas mais pobres). No entanto, apesar dessa relativa melhora em relação à informação, permanece-se, no país, acompanhando o crescimento dessa taxa. Por isso, considera-se necessário caminhar um pouco mais além, aprofundar o conhecimento do perfil dessas mortes e buscar os possiveis fatores associados, visando ao estabelecimento de algumas medidas para a sua prevenção.

Verifica-se que este é um movimento que vem ocorrendo com os estudos acerca da violência de vários outros países, pois cresce, na literatura internacional, o número de pesquisadores ampliando seus trabalhos para além daquelas variáveis mais comumente estudadas, tais como faixa etária e sexo. Em estudo realizado a partir de dados de emergência hospitalar no Canadá (MacDonalds e col., 1999) comparando as vítimas de lesões por acidentes com as vitimas de lesões intencionais, revelou que o sexo masculino, a baixa 
renda, o consumo de álcool, local de ocorrência em bar ou restaurantes estavam fortemente associados às vítimas de violência intencional. Em Los Angeles, buscou-se identificar as relaçōes entre fatores sócio-econômicos e a incidência de homicidios entre gangues, examinando vários fatores selecionados, tendo concluído que estes tipos de homicídios estavam significantemente associados com baixa renda e desemprego (Kyriacou e col, 1999).

Um estudo realizado no Recife (Falbo e col, 2001), com o objetivo de identificar fatores potencialmente modificáveis para homicídios, revelou como fator de risco a existência de histórico de registros policiais anteriores e o uso de drogas ilícitas, entre outros. Foram encontrados como fatores protetores, maior grau de escolaridade e religião.

$\mathrm{Na}$ verdade, parece inadiável a elaboração de um sistema de informação que ajude a entender o que está acontecendo na sociedade. Hoje, existe uma série de órgãos produtores de informações nessa área, algumas geradas com a finalidade de acompanhamento estatístico; outras, não, segundo a lógica interna da Instituição que as produzem, não sendo elas, entretanto, comparáveis entre si.

\section{- Prevencão eviolencias}

"As maiores barreiras que encaramos na prevenção da violência são o medo, a frustração e o sentimento de falha. Violência é um problema de tão enormes proporções e complexidade que é fácil e totalmente comum sentir-se esmagado em confrontá-la." (Satcher, 1996; Centers for Desease Control and Prevention) 
Os relatos de experiências de outras nações e também nacionais reafirmam que é possivel prevenir um grande número dessas mortes. Cabe ressaltar que, entre as causas externas ocorridas no Município de São Paulo, o número de mortes por acidentes de trânsito, agravo cuja prevenção também requer uma modificação do comportamento individual e social, vem diminuindo. A experiência tem demonstrado que é imprescindivel o envolvimento de outros setores, que pela característica de suas atividades ou interesses correlatos, os aproxima das preocupações do setor saúde.

Trabalhando em campos aparentemente opostos, pois a área da saúde cuida das vítimas, enquanto a Segurança Pública tem o seu foco no agressor, esses setores devem estar envolvidos articuladamente nas propostas de redução da violência. Também podem ser identificadas as áreas da Educação e Bem Estar Social que, além de produzirem informações sobre o tema, convivem intimamente com o problema, já tendo acumulado experiências, angústias e iniciativas que por certo devem contribuir para a abordagem das violências. Para se ter uma aproximação maior destes fatores de risco e desenhar soluções possiveis, considera-se imprescindivel reunir essas informações.

No que diz respeito à área da saúde, a sua interface mais óbvia com a violência é o tratamento dos feridos, a reabilitação dos seqüelados e, por último, a contagem dos mortos. Atualmente, as causa externas têm um forte impacto negativo sobre os índices de saúde como, por exemplo, na expectativa de vida: cálculos realizados para o Estado de São Paulo mostraram que estas causas roubam três anos de vida do sexo masculino (Camargo, 2002). Nos últimos anos, a Saúde Pública comemorou a diminuição das mortes por doenças infecciosas e parasitárias, mas Noronha (2002) chama a atenção para o fato de que o quanto se ganhou em vidas por essa redução perdeu-se quase o dobro por causas externas.

Nos Estados Unidos da América, observou-se redução das taxas de crimes violentos em várias cidades, sendo o caso mais famoso o da cidade de 
Nova York, com a sua política de "Tolerância Zero", que fez diminuir a criminalidade e priorizou a revitalização de bairros deteriorados.

Desde 1992 e 1993, o National Center for Injury Prevention and Control do Centers for Desease Control and Prevention (CDC) avaliou alguns projetos desenhados com o objetivo de reduzir a freqüência e a gravidade da violência interpessoal entre os jovens. Todas as intervenções foram baseadas em modelos elaborados a partir de pesquisas científicas anteriores. A maior parte desses projetos, envolvem a escola, com participantes que vão desde 5 até os 18 anos. O CDC apontou a existência de pouca informação acerca da efetividade de atividades de prevenção de violência entre jovens (Satcher, 1996).

No Brasil, há relatos não avaliados ainda de maneira sistemática de que projetos sociais, com a participação da comunidade e empresas, tais como o do Morro da Mangueira, na cidade do Rio de Janeiro, têm ajudado a diminuir a criminalidade naqueles locais, por oferecerem outras opções para as crianças e jovens. Projetos de reformas no espaço urbano de algumas favelas, também no Rio de Janeiro, abrindo vias públicas e colocando iluminação, onde antes não existia, somente por permitir a circulação de viaturas de polícia e de carros particulares, inibiram o tráfico de drogas ostensivo, reduzindo as ações violentas que ocorriam nesses locais (tanto do tráfico, quanto da polícia). É possivel verificar que algumas soluções podem ser mais simples do que se imagina.

\subsection{Vigilância Epidemiológica das Violências: um novo desafio}

Apesar da sua importância para a Saúde Pública, um projeto para a prevenção da violência ainda não ocupa lugar de destaque entre os programas dessa área. Verifica-se uma certa paralisia na abordagem de um problema 
cujo alcance é, indubitavelmente, mais amplo que o setor saúde, discutindo-se o fato de ele estar relacionado com a desigualdade social, com o rico e poderoso comércio ilegal de armas de fogo e tráfico de drogas, a ineficiência da justiça, entre outros

Esta inércia pode ser também verificada em outros paises da América Latina, tais como a Colômbia que, segundo Guerrero (1997), desenvolve programas bem estruturados para a cólera e a AIDS, doenças cujo número de casos é, respectivamente, de 1989 e 1341 casos, enquanto poucos esforços são feitos para diminuir a violência, que mostra a ocorrência de 26.778 homicídios.

Por que, apesar de números tão expressivos, os profissionais da área da saúde ainda crêem que a violência é um problema externo a ela? Provavelmente pela sua forte dependência dos fatores socioeconômicos. Porém, não se deve esquecer que tais fatores são encontrados em praticamente qualquer doença que afete o ser humano.

Para Pearce (1996), um povo tem uma história, cultura, organizações social e econômica, que influenciam como as pessoas são expostas a fatores de risco: "as causas da cólera na índia hoje são decorrentes de séculos de história, desde a invasão britânica e da destruição da sua próspera indústria têxtil; a manutenção de arcaicos sistemas de propriedade da terra e agricultura; a persistência de um sistema de castas e a inacreditável pobreza, fome e superpopulação; a conseqüente inabilidade para sustentar 0 desenvolvimento de reservatórios e fornecimento de água tratada; e quase incidentalmente, a presença do vibrião da cólera".

Como este, podem ser citados inúmeros outros exemplos. Também as doenças crônicas, tais como diabetes, hipertensão arterial, ou câncer de colo uterino, têm gênese ou controle estreitamente relacionados às condições sociais dos atingidos. Enfim, frente aos conhecimentos atuais, não é mais possivel considerar que seja propriedade exclusiva da violência esta dependência dos fatores sociais. Na verdade, a violência se configura como 
mais um agravo, complexo e com uma série de dificuldades para lograr a sua prevenção, com que deve lidar a Saúde Pública.

Um passo pioneiro foi dado pela Secretaria de Estado de Saúde de São Paulo, em 1997, quando reuniu um grupo multi-institucional, para o qual foram convidados representantes de órgãos da Secretaria de Estado da Saúde, Secretaria de Segurança Pública, Secretaria da Justiça, Universidade (Núcleo de Estudos da Violência da USP, Faculdade de Saúde Pública da USP) e Programa de Aprimoramento em Informações de Mortalidade do Município de São Paulo, o PRO-AIM, com o objetivo de elaborar um sistema de vigilância epidemiológica para os homicídios. Foram selecionadas algumas variáveis e fontes de interesse, com base em proposta elaborada pela Organização Panamericana da Saúde (OPS, 1996), e que fossem imediatamente disponiveis, ou seja, não se pretendia criar qualquer novo instrumento, mas simplesmente utilizar a informação que já vinha sendo produzida.

Dois grandes resultados merecem ser apontados: o primeiro deles foi o conhecimento da produção das informações nesses órgãos (que a maior parte do setor saúde desconhecia), ou seja, como coletam e trabalham os dados e as suas limitações. E, o segundo, a indispensável sensibilização dessas Instituições que foram envolvidas, para a realização de trabalhos intersetoriais.

Por essa experiência, mesmo não tendo sido levada adiante naquele momento, acredita-se que se possa estabelecer um sistema de vigilância de homicídios para o Municipio de São Paulo, de baixo custo e de fácil execução, que permita acompanhar as informações e fornecer as bases científicas para propostas de ações de controle.

\section{- Por que estudar a mortalidade?}

Freqüentemente é utilizada a metáfora da ponta do iceberg para ilustrar os estudos de causas externas que utilizam somente os dados de mortalidade, 
pois seriam perdidos inúmeros casos em que pacientes são internados ou somente passam pelas emergências médicas e não vão a óbito. Considera-se, por outro lado, que esta imagem pode não se aplicar com a mesma força para os homicidios, pois, tratando-se de lesão intencional grave, a existência de um número grande de casos que tiveram somente um atendimento na emergência e foram liberados posteriormente é menos provável.

Reforça tal hipótese, uma recente pesquisa realizada nos setores de emergência de dois grandes hospitais públicos do Rio de Janeiro (Deslandes, 1999), onde foram levantados os atendimentos decorrentes de acidentes e violências. Diferentemente dos dados de mortalidade, as quedas representaram a causa de procura mais freqüente (cerca de $32 \%$ ), enquanto as agressões (tentativas de homicidio e outras agressões) foram responsáveis por somente cerca de $6 \%$ do total de atendimentos. Também no Hospital das Clinicas da Faculdade de Medicina da Universidade de São Paulo, considerado o maior pronto-socorro do país, uma pesquisa por amostragem, realizada entre agosto de 1998 e agosto de 1999, entre pacientes admitidos por causas externas, revelou que os acidentes de transporte responderam por $47,2 \%$ dos atendimentos e as agressões, por 25,6\% (Carvalho, 2002).

Em relação às internações, sabe-se que, têm sido responsáveis por 5 a $6 \%$ do total de internações do Pais (Lebrão e col., 1997), na última década, principalmente devido às fraturas $(37,5 \%$ das internações por causas externas), que devem corresponder aos acidentes de transporte, trabalho e quedas. Os ferimentos e lesões traumáticas dos vasos sangüineos, em que presumivelmente estão englobadas as agressões por arma de fogo e arma branca, foram responsáveis por $17,5 \%$ do total desse grupo.

Mas, por certo, a melhor identificação da magnitude da morbidade por violências e também uma estimativa das possiveis seqüelas e incapacidades decorrentes (que hoje é um terreno ainda bastante desconhecido), deveria ser objeto de estudos posteriores. Mello Jorge \& Yunes (2001) referem que, em 1997, na Rede Sarah de Doenças do Aparelho Locomotor (Brasilia), do total de pacientes atendidos, $42,2 \%$ foram vítimas de acidentes de trânsito, $24,0 \%$ 
de disparos de armas de fogo, $13 \%$ de mergulhos em águas rasas, $11,6 \%$ por quedas e 9,5\% por outros tipos de acidentes e violências. Em relação a São Paulo, a Associação de Assistência à Criança Defeituosa - AACD - aponta uma mudança no perfil dos pacientes adolescentes atendidos, pois há alguns anos, estes eram preferencialmente vítimas de acidentes de trânsito, enquanto hoje são alvos de assaltos e balas perdidas. No ano 2.000 , entre os $63 \%$ menores de 18 anos que iniciaram tratamento na AACD por lesões na medula, $47 \%$ deles foram feridos por armas de fogo, enquanto $16 \%$ foram vítimas de atropelamento. A maioria dos casos é da Capital do Estado ${ }^{5}$.

\section{- Uma proposta para Vigitâncía Epidemiológica dos homicidios}

"Os Sistemas de Vigilância não precisam ser perfeitos para serem úteis" (Waldman, 1998)

Dada a magnitude do problema dos acidentes e violências, a vigilância epidemiológica enquanto inıstrumento de coleta, análise e interpretação de dados específicos para ser utilizado no planejamento, avaliação e execução da prática de Saúde Pública, foi proposta pela Organização Panamericana de Saúde em uma oficina de trabalho realizada na Colômbia, no final do ano de 1994 (OPS, 1996). Também é uma das diretrizes estabelecidas no documento da Política Nacional de Redução da Morbimortalidade por Acidentes e Violências (Brasil, 2001).

Certamente, quando se propõe a elaboração de proposta de vigilância isto é devido ao fato de ser este um dos instrumentos da Saúde Pública mais consagrados e conhecidos em nível mundial, principalmente devido à

\footnotetext{
${ }^{5}$ Jornal $O$ Estado de São Paulo. caderno Cidades. 3 de setembro de 2001.
} 
campanha de erradicação da varíola, nas décadas de 60 e 70 (Waldman, 1998)

Conceitos

A homogeneização dos conceitos básicos, entendidos como aqueles que definem o que é um sistema de vigilância em saúde pública, comuns a qualquer agravo à saúde, a qual seja aplicada, deve ser o passo inicial.

Assim, torna-se preciso conceituar o que se denomina vigilância epidemiológica. De acordo com Waldman (1998), o conceito mais utilizado, atualmente, é o de Langmuir: "Vigilância é a observação contínua da distribuição e tendências da incidência de eventos adversos à saúde mediante a coleta sistemática, consolidação e avaliação de informes de morbidade $e$ mortalidade, assim como de outros dados relevantes, e a regular disseminação dessas informações a todos os que necessitam conhecê-la". Desse modo, a vigilância não se preocupa mais somente com contatos de doenças infecciosas, passando a acompanhar o comportamento de eventos adversos à saúde na comunidade, com vistas a recomendar, em tempo oportuno, estratégias de prevenção e controle, fundamentadas no conhecimento científico

Vale a pena também apresentar, o conceito utilizado pela Fundação Nacional de Saúde (FUNASA, 2001), pois este é o órgão responsável pela Coordenação do Sistema Nacional de Vigilância Epidemiológica no país, definido como "o conjunto de atividades que permite reunir a informação indispensável para conhecer, a qualquer momento, o comportamento ou história natural das doenças, bem como detectar ou prever alterações de seus fatores condicionantes, com o fim de recomendar oportunamente, sobre bases firmes, as medidas indicadas e eficientes que levem à prevenção e ao controle 
de determinadas doenças e agravos" (Lei Orgânica da Saúde - Lei 8080, de 1990).

Em relação às suas características principais, um Sistema de Vigilância deve:

1. ser simples;

2. ser contínuo;

3. ter obrigatoriamente três componentes: a informação, a análise regular da informação com fundamento no conhecimento científico e ampla disseminação da informação analisada a todos que dela necessitam (Waldman \& Mello Jorge, 1999).

Em relação aos seus propósitos, o Sistema de Vigilância precisa:

1. identificar e acompanhar a magnitude do problema e a tendência;

2. descrever a população vulnerável;

3. identificar fatores de risco potenciais e fatores associados;

4. coletar e acompanhar, de forma ágil, as informações, bem como a tendência no tempo;

5. recomendar, com bases objetivas e cientificas, as medidas necessárias para prevenir ou controlar a ocorrência de agravos especificos à saúde;

6. avaliar o impacto de medidas de intervenção;

Mas, esse sistema de vigilância obedeceria ao mesmo modelo das doenças infecciosas? Com certeza isso não deve ser possivel, haja vista as caracteristicas desse agravo já discutidas anteriormente. A maior parte das doenças sob vigilância, atualmente, em nosso país, aciona o sistema quando é realizada a suspeita de um caso, em razão da existência de medidas profiláticas a serem conduzidas para proteger os comunicantes e impedir o surgimento de novos casos. Em relação à vigilância dos homicídios, o mais adequado seria não elaborar programa com medidas individuais, mas sim trabalhar com os grupos populacionais expostos ao risco. 
É importante assinalar que, isso não deve ser uma regra para todas as violências, pois se o objetivo for elaborar políticas de prevenção para grupos específicos, como é o caso da violência contra a mulher e criança é possível que estabelecer medidas individuais seja o mais adequado. Este é o caso, por exemplo, da notificação de maus tratos contra a criança e adolescentes (até 18 anos) que é prevista na Lei № 10.498 , de 05 de janeiro de 2000 , publicada no Diário Oficial do Estado, em 6 de janeiro de 2000, que retrata o estabelecido no Estatuto da Criança e do Adolescente (Brasil, 1990).

Certamente, mesmo em relação aos homicídios, a familia, amigos e vizinhança envolvida, por certo, se beneficiariam de atendimento individual, mas, neste momento, considera-se que o mais importante é trabalhar com os grupos populacionais expostos ao risco.

Em relação ao tipo de sistema, considera-se mais adequado um sistema de vigilância ativa, na medida em que prevê o contato regular entre a equipe de vigilância e as equipes das fontes de informação. Cabe lembrar que o sistema passivo é aquele constituído de notificações espontâneas dos serviços de saúde, que traz a desvantagem de ter menos sensibilidade que $\circ$ primeiro, pois conta com a adesão de cada serviço ou profissional envolvido. Outra desvantagem é o tempo para que muitos profissionais conheçam o sistema de vigilância e passem a fazer a notificação.

\subsection{A presente proposta}

Optou-se por trabalhar com dados de mortalidade por homicídios, dada a incontestável magnitude do problema, e por entender ser esta a manifestação extrema da violência intencional. Além disso, são informações confiáveis, ágeis e atualmente acessíveis (imediatamente disponíveis). 
Devido à existência de várias fontes - isoladas e elaboradas, com propósitos diversos - o presente trabalho visa estabelecer um perfil da mortalidade por homicídios no Município de São Paulo, por meio da exploração das várias fontes oficiais de registros e integração das informações nelas existentes.

Considerando que a reunião desses dados constitui um desafio crítico para o desenvolvimento de um Sistema de Vigilância para os homicídios, espera-se, desse modo, fornecer subsídios para a implantação de tal sistema, cuja finalidade seria não somente acompanhar a magnitude do problema, mas também ampliar o conhecimento sobre as caracteristicas das vítimas, bem como das circunstâncias em que se deu o ato violento.

Mas, sobretudo, foi pelo desejo de avançar a compreensão sobre esta grave questão e, conseqüentemente, ampliar a capacidade de ação do setor saúde a razão pela qual este trabalho foi realizado. 
2. Objetivos 
Estudar os homicídios na população residente do Município de São Paulo com o propósito de estabelecer um perfil epidemiológico dessas ocorrências, tanto das características das vítimas quanto dos eventos, por meio da integração das informações existentes nos registros oficiais, de forma a fornecer subsidios para a formulação de um modelo de Sistema de Vigilância Epidemiológica para os Homicidios nesse Município. 
3. Material e Método 
Este estudo foi dividido em três etapas, ilustradas na Figura 5. Para cada uma delas, o material utilizado está descrito a seguir:

Primeira etapa - estudo do perfil das vítimas por meio das Declarações de Óbito (DO):

Análise do universo de óbitos por homicidios ocorridos no Município de São Paulo, entre seus residentes, no ano de 2000, registrados no PRO-AIM, um total de 5.978 mortes. Os óbitos ocorridos em outros municípios não encontram-se englobados nesse total.

Segunda etapa - ampliação do perfil da vitima e estudo das circunstâncias do ato violento, por meio da associação das informações provindas das diversas fontes:

Análise dos óbitos ocorridos por homicídios, ocorridos nos meses de abril, maio e junho do ano 2000, somando um total de 1.387 mortes, registradas no PRO-AIM, completadas com os correspondentes 1.384 laudos de necropsia (3 laudos não foram encontrados) e os 1.313 Boletins de Ocorrência Policial - BOs - (74 BOs não foram encontrados).

Terceira etapa - estudo dos perfis das vitimas e agressores por meio das informações obtidas nos inquéritos policiais

Foram analisadas as informações fornecidas pelo Departamento de Homicídios e Proteção à Pessoa (DHPP), que foram coletadas de 648 inquéritos policiais investigados naquele Departamento, referentes aos óbitos ocorridos no Município de São Paulo, no ano 2000. Esse número representa $29,4 \%$ de um total de 2.202 óbitos que foram encaminhados para investigação naquele serviço e correspondia aos inquéritos que já haviam sido encerrados no momento da pesquisa. 
Homicídios ano 2000

5978

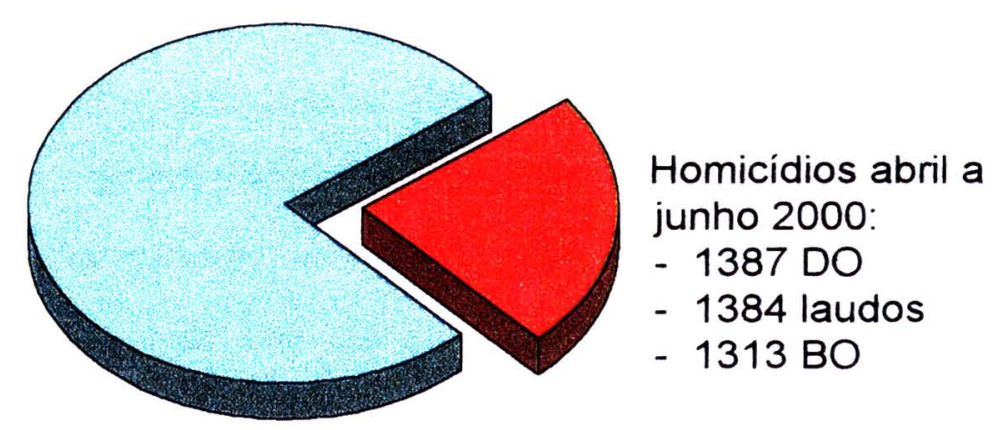

Estudo dos homicídios - DO + BO + IML

Homicídios ano 2000

5978

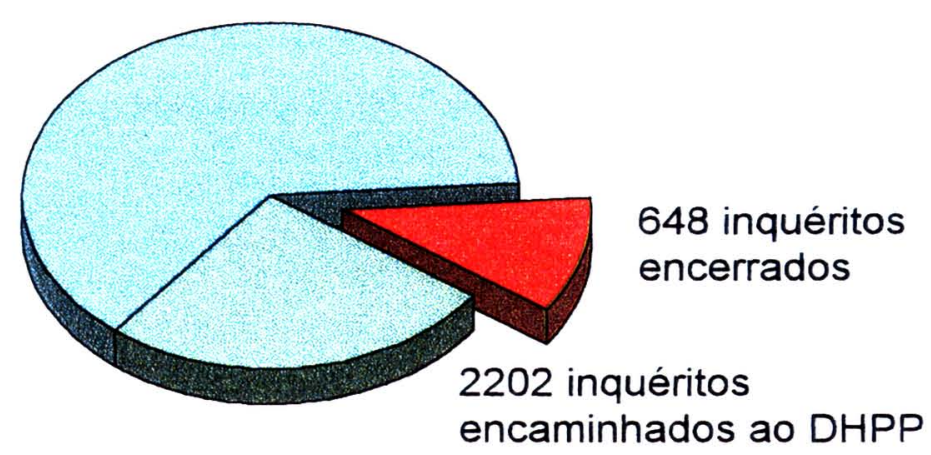

Estudo dos homicídios - inquéritos encerrados no DHPP

Figura 5: Material do estudo, homicídios segundo fontes, Município de São Paulo, 2000.

\subsection{Conceitos utilizados}

Para as finalidades deste trabalho, sem qualquer pretensão de esgotar o assunto, foram adotados os conceitos listados abaixo, adaptados de publicação da Organização PanAmericana da Saúde (OPS, 1996): 
- Violência: é o ato premeditado ou não que tem como produto o dano na integridade física, psíquica, sexual, na personalidade, ou ainda na liberdade de movimento da vítima. Se não há intenção, o ato se classifica como acidente.

- Lesão intencional: é aquela produzida a uma pessoa com intenção de gerar um dano físico. Pode ser contra o outro (homicidio) ou contra si mesmo (suicídio).

- Homicídio: é o ato pelo qual uma pessoa mata a outra intencionalmente.

- Vitima: pessoa que sofre as conseqüências de uma ação violenta.

- Agressor: é a pessoa que comete a violência.

\subsection{Fontes de informação}

São várias as fontes de registro produzidas a partir da ocorrência de um óbito por homicídio no Município de São Paulo. Os passos desse fluxo são apresentados a seguir. Cabe lembrar que o sistema policial brasileiro é constituido por duas instituições distintas, uma civil e outra militar, sendo que à Polícia Militar cabe a função do patrulhamento preventivo e ostensivo e, à Polícia Civil, a investigação da ocorrência e abertura do inquérito.

1. Policial Militar: é a primeira autoridade que chega ao local, seja avisada pela população pelo telefone 190 ou por meio do policiamento preventivo. É responsável pela preservação desse local. Realiza registros acerca da vitima e das circunstâncias do evento e avisa a Delegacia da área. 
2. Delegacia Policial: encaminha telex para o IML (hoje via on-line), para proceder a retirada do corpo. Esse telex, por não ser um instrumento padronizado, pode conter ou não informações a respeito das circunstâncias do fato. Ao lado disso, é aberto um Boletim de Ocorrência (BO) com vistas ao início da investigação. Atualmente esses documentos são digitados em sistema on-line, podendo ser consultados na Coordenadoria de Análise e Planejamento (CAP), órgão da Secretaria de Segurança Pública do Estado de São Paulo.

Para aqueles homicidios cuja autoria é desconhecida, a documentação é encaminhada para a Delegacia de Homicídios e Proteção à Pessoa (DHPP), que abre um novo Boletim de Ocorrência.

3. Instituto Médico Legal: realiza a necropsia e emite dois documentos: o laudo da necropsia e a Declaração de Óbito (DO); esta última constitui-se no documento "prova da morte", básico para o registro do evento com posterior emissão da certidão do óbito, pelo cartório, necessário para a realização do funeral (Laurenti \& Mello Jorge, 1996; Silveira, 1996).

4. PRO-AlM: tem as cópias de todas essas DOs, sendo então codificadas, tendo todos os seus campos digitados.

Estes são os registros mais imediatos. Pode-se definir o Boletim de Ocorrência como o documento oficial, onde é registrada a notícia do crime, devendo conter o máximo de dados sobre autoria e circunstâncias materiais do fato. Essa notícia, tratando-se de um homicídio, sempre faz gerar um inquérito policial.

5. Inquérito Policial: é o instrumento com o qual é realizada a investigação do delito. Para a sua instauração, é preciso publicação em Diário Oficial, o que pode se dar muito rapidamente, especialmente em 
um crime de homicídio. O tempo para o seu encerramento pode variar muito, conforme o caso, podendo levar mais de ano.

\subsection{Variáveis selecionadas}

Os critérios que nortearam a seleção das variáveis realizada para este trabalho foram utilidade e disponibilidade imediata nos registros, visto que um dos objetivos do trabalho é demonstrar a importância e viabilidade da implantação de um sistema de vigilância para os homicídios.

Algumas das variáveis selecionadas encontram-se disponiveis em uma única fonte, tais como o local de ocorrência ou a motivação do fato. Outras podem ser obtidas em várias fontes, tal como a idade, habitualmente preenchida através de documentos legais da vítima constando tanto no Boletim de Ocorrência quanto na Declaração de Óbito. E ainda há aquelas, como a cor da vítima, que, embora possa ser obtida também em várias fontes, é considerada uma informação pouco confiável.

Portanto, para cada variável escolhida, uma fonte foi priorizada. Para aquelas que podem ser encontradas em vários locais, a informação que consta na Declaração de Óbito foi a escolhida. Isto se deve ao fato de que este é o documento legal de comprovação da morte (Laurenti \& Mello Jorge, 1996; Silveira, 1996), sendo geralmente preenchido com base em documentos exibidos pela família da vítima, tais como o Registro de Identidade, Certidão de Nascimento ou Casamento, entre outros. Além disso, estes dados são os utilizados oficialmente na produção das estatísticas vitais. Em relação às outras variáveis, algumas escolhas são naturais (por exemplo, é no laudo de necropsia que se espera encontrar a informação da natureza da lesão) e para outras se buscou a experiência anterior do grupo de trabalho da Secretaria de Saúde do Estado de São Paulo (Gawryszeswki, 1998). 
1. Idade: utilizou-se a informação da DO.

2. Sexo: o mesmo que o anterior. Nos casos de sexo ignorado, foi realizada consulta aos laudos do IML.

3. Local de residência: foi utilizada a informação da D.O. São dois os campos digitados: o distrito e endereço completo. O primeiro foi utilizado para a construção das taxas.

4. Estado civil: foi utilizada a informação da DO.

5. Uso de substâncias psicoativas (álcool e outras substâncias psicoativas): foi obtido nos laudos do IML. Certamente, seria de grande valor se esta dosagem fosse realizada para todos os óbitos por causas externas, pois a relação entre o uso de álcool e outras substâncias psicoativas e a morbimortalidade por causas externas é conhecida, a partir principalmente de dados da literatura internacional, sendo poucos os estudos para o nosso meio sobre esta questão.

6. Natureza da lesão: o único lugar onde é registrada a natureza das lesões é o laudo do IML.

7. Causa básica da morte: foi utilizada a DO. O PRO-AIM codifica as causas básicas de morte, utilizando a Classificação Internacional de Doenças $10^{\mathrm{a}}$ revisão (Capitulo XX) (OMS, 1995). Estes óbitos encontram-se no agrupamento Agressões (X85-Y09), ao qual foi acrescido o das chamadas Intervenções legais e operações de guerra (Y35-Y36), no sentido de incluir os óbitos cujo agente foi a autoridade policial.

8. Data da ocorrência: foi utilizada a informação que consta no Boletim de Ocorrência, uma vez que, na Declaração de Óbito, é registrada a data do óbito, o que não necessariamente corresponde ao dia em que ocorreu a tentativa de homicídio.

9. Horário da ocorrência: foi utilizada a informação que consta no Boletim de Ocorrência.

10.Local de ocorrência (endereço completo) (Fonte: BO/SSP): a partir dos dados constantes na $\mathrm{DO}$, somente se conhece o local de residência dessas vítimas. No entanto, para o estudo das causas externas, isso não basta, 
sendo o conhecimento do local de ocorrencia dos eventos violentos fator de grande importância para o planejamento de programas de prevenção. Essa informação também permite estabelecer a relação entre local de ocorrência do evento e local de residência da vitima.

11.Tipo de local (se residência, via pública, bar, clube etc): a fonte onde foi obtido este dado foi o $\mathrm{BO}$.

12. Motivo, entendido como o que levou ao cometimento do evento (desavenças, chacina, latrocínio etc): coletado no BO, na parte do histórico onde existem alguns relatos das circunstâncias do fato.

13.Meio utilizado (arma branca, arma de fogo, enforcamento etc): Sabe-se que o preenchimento da DO ainda é falho para o conhecimento fidedigno deste dado pois, muitas vezes, o legista descreve tecnicamente a lesão, não explicitando nesse documento, ser a lesão conseqüência de ferimento por arma de fogo.

14.Assistência médica: esta informação foi obtida nos laudos do IML e BOs. $O$ objetivo é fornecer subsídios para $O$ aprimoramento da atenção médica às vítimas, reduzindo a mortalidade.

Em relação aos inquéritos, foram acrescidas as seguintes variáveis:

\section{Grau de escolaridade}

\section{Situação de emprego na ocasião do evento}

17.Uso de substâncias psicoativas: por meio de informações constantes nos depoimentos;

\subsection{Método}

Na etapa 1, foi utilizado apenas o banco de dados do PRO-AIM, onde constavam 5.978 homicídios (dados para o ano de 2000). 
Em relação à etapa 2, referente à integração de dados das diversas fontes, optou-se por estudar apenas três meses, devido à dificuldade de se completarem as informações constantes da DO, para o universo dos casos de homicídios ocorridos no ano de 2.000. Ainda que não tenham sido verificados relatos de sazonalidade marcante para os homicídios, foram escolhidos os meses de abril, maio e junho. A complementação dos dados que constavam nas DOs foi realizada, para cada uma das vítimas, do seguinte modo:

- os dados constantes nas Declarações de Óbito, disponibilizados em meio magnético pelo PRO-AIM, constituiu-se na base de dados. A partir desse banco, foi elaborada uma lista desses registros, que posteriormente, teriam as informações completadas nas duas outras fontes.

- laudos de necrópsia emitidos pelo IML: este órgão arquiva os documentos originais, por isso houve busca manual para cada um dos laudos;

- os Boletins de Ocorrência Policial gerados por esses eventos: também foram pesquisados caso a caso; aqueles que estavam no CAP puderam ser procurados via magnética, por meio de programa Infocrim, enquanto para aqueles que se encontravam no DHPP, a busca teve que ser manual.

A etapa 3 foi realizada buscando estabelecer quais as informações que poderiam ser obtidas nos inquéritos policiais e a viabilidade desse documento fazer parte de um sistema de vigilância. Os dados foram coletados pelas próprias equipes do DHPP e disponibilizados para análise.

Os dados utilizados para a população foram fornecidos pela Fundação SEADE, a partir do censo 2.000, realizado pela Fundação IBGE (IBGE, 2002).

Estes óbitos foram estudados em seus números absolutos, proporções e coeficientes. Para estudar a relação entre as variáveis distribuídas espacialmente segundo os distritos do Município de São Paulo, foram construídos diagramas de dispersão e calculados o coeficiente de correlação linear de Pearson com nivel de significância de $5 \%$. O software que foi utilizado na maior parte das análises foi Epi-Info e, para os cálculos estatisticos, o Excell. 
4. Resultados e discussão 
Os resultados apresentados a seguir dizem respeito aos 9171 óbitos por acidentes e violências, ocorridos no Município de São Paulo, em residentes deste município, no ano de 2000. A Tabela 1 mostra a distribuição desses óbitos quanto aos tipos de acidentes, por meio de números absolutos, proporções e coeficientes, segundo sexo. Ocorreram 1.183 óbitos por acidentes de transporte, 425 suicídios, 5.978 homicídios, 1.250 considerados "Demais acidentes", restando 335 mortes em que se ignorava se foram acidentais ou intencionais. É importante salientar que o esclarecimento dessas causas pode fazer aumentar ainda mais a proporção de homicidios. Souza (1994), analisando dados para o Rio de Janeiro, apontou falhas na qualidade da informação, levando a grande subestimação do número de homicídios ocorridos naquele local.

Tabela 1:

Óbitos por causas externas, segundo Sexo e tipo de acidente ( $n^{\circ}, \%$ e coeficientes/100.000 habitantes). Municipio de São Paulo, 2000.

\begin{tabular}{lccccccccc}
\hline & \multicolumn{3}{c}{ Masculino } & \multicolumn{3}{c}{ Feminino } & \multicolumn{3}{c}{ Total } \\
Tipo & No & $\%$ & Coef & No. & $\%$ & Coef & No. & $\%$ & Coef \\
\hline Ac. Transp. & 914 & 11,6 & 18,3 & 267 & 21,1 & 4,9 & 1183 & 12,9 & 11,3 \\
Demais Ac. & 854 & 10,8 & 17,2 & 395 & 31,3 & 7,2 & 1250 & 13,6 & 12,0 \\
Homicídios & 5527 & 70,0 & 111,1 & 446 & 36,1 & 8,2 & 5978 & 65,2 & 57,3 \\
Suicidios & 321 & 4,1 & 6,5 & 104 & 8,2 & 1,9 & 425 & 4,6 & 4,1 \\
Ignorado & 282 & 3,5 & 5,7 & 51 & 4,0 & 0,9 & 335 & 3,6 & 3,2 \\
\hline Total & 7898 & 100,0 & 158,8 & 1263 & 100,0 & 23,1 & 9171 & 100,0 & 87,9 \\
\hline \hline
\end{tabular}

Os acidentes de transporte compõem $12,9 \%$ do total das mortes, mantendo tendência de redução de seus índices que vinha sendo verificada na análise da série histórica de causas externas do Município de São Paulo (Mello Jorge, 1979 e 1982; Gawryszewski, 1995; Gawryszewski \& Mello Jorge, 2001), ocorrida a partir da década de 80 (ver Figura 3). O coeficiente de 
mortalidade encontrado para o sexo masculino foi de 18,3 e, para o feminino, de 4,9 (ambos medidos por 100.000 habitantes). A razão entre os coeficientes masculino/feminino para os acidentes de transporte é 3,7; mais baixa que aquela encontrada para o total das causas externas $(6,9)$.

Nos países desenvolvidos a contribuição percentual desses óbitos para - total das causas externas costuma ser mais alta, mas os valores dos coeficientes são próximos aos encontrados para o Municipio de São Paulo (11,3/100.00 habitantes); ressalte-se, porém, que esses dados não são padronizados. Como exemplos, podem ser citados a França, cuja taxa de mortalidade por acidentes de trânsito foi de 14,2, no ano de 1994 (United Nations, 1999), o Canadá, que teve taxa de 10,4 para o ano de 1995 , e os Estados Unidos com taxa de 15,6, para 1997. Já o Brasil, apresenta valores maiores, 20,4 (Yunes \& Zubarev, 1999).

As mortes devidas aos suicídios foram $4,6 \%$ do total, e o coeficiente verificado neste ano foi de 4,1/100.000 habitantes, confirmando uma tendência de estabilidade desses índices. Nesse aspecto, esse valor é bem diferente daqueles encontrados nos países desenvolvidos. Os dados para o ano de 1995 (United Nations, 1999) mostram que, na França, esse coeficiente chegou a 20,8; no Canadá, a 13,5 e nos EUA, a 11,9 (todos por 100.000 habitantes).

No Município de São Paulo, no ano 2000, os óbitos por suicídios no sexo masculino foram 321 (75,5\%); no feminino, 104 (24,5\%). Os coeficientes encontrados para cada sexo foram: 6,5 por 100.000 homens e 1,9 por 100.000 mulheres. A razão entre os coeficientes masculino/feminino encontrada é menor do que a dos outros tipos de causa: 3,4 .

O grupo dos demais acidentes foi responsável por $13,6 \%$ do total de óbitos, cujo coeficiente foi 12,0/100.000. Do ponto de vista da série histórica, essa taxa confirma a estabilidade que já vinha sendo verificada. $O$ sexo masculino contribuiu com 854 óbitos (68,3\%) e o feminino, com 395 (31,7\%). 0 coeficiente para o sexo masculino foi de 17,2 por 100.000 homens e de 7,2 por 100.000 mulheres. A razão entre os coeficientes masculino/feminino foi de 2,4 ; menor que a encontrada para o total das causas externas. 
As mortes em que não foi possivel determinar se acidental ou intencional (ignorada) representaram 3,6\% do total, esse percentual vem diminuindo ao longo do tempo, revelando uma melhor qualidade da informação no Municipio de São Paulo.

Certamente chama atenção o grupo dos homicidios, que representa mais que a metade $(65,2 \%)$ do total de mortes. Para maior facilidade de entendimento, os resultados das etapas 1 e 2 são apresentados nos itens seguintes, havendo menção especifica a cada fonte de informação desses homicidios.

\subsection{Perfil das vitimas}

\section{- Sexo e idade}

Os 5978 homicidios ocorridos em 2000 são mostrados na Tabela 2, sob a forma de números absolutos, proporçōes e coeficientes, segundo sexo e faixa etária. A idade que apresentou o maior número de óbitos (moda) foi 20 anos.

Analisando, inicialmente, as proporções encontradas, observa-se predominância acentuada do sexo masculino, com $92,5 \%$ do total das mortes por homicídios. Para o total das causas externas, esta sobremortalidade encontra-se em crescimento no Município de São Paulo, decorrente do aumento da participação dos homicidios, em que o predomínio do sexo masculino é ainda mais acentuado.

Em relação aos coeficientes de mortalidade (por 100.000 habitantes), os dados do ano 2000 mostram valores altos: 57,3 para o total da população; 111,1 para o sexo masculino e 8,2 para o feminino. A razão entre sexos desses coeficientes é 13,5. 
Os jovens e adultos do sexo masculino concentram a maioria dos óbitos, visto que na faixa de 15 a 39 anos estão $78,1 \%$ das mortes por homicídios no sexo masculino e $83,4 \%$ do total dos homicídios. Decorrente disso, os coeficientes nessa população chegam a valores alarmantes, destacando-se os seguintes grupos: dos 20 aos 24 anos, com taxas atingindo 286,4/100.000; dos 25 aos 29 anos, $241,7 / 100.000$ e dos 15 aos 19 anos, 214,7/100.000 (figura 6). Isso faz com que a faixa etária dos 15 aos 29 anos seja a que concentra, mais do que qualquer outra, o maior número de homicídios e os maiores coeficientes, determinando, assim, perdas precoces de vida. Essa faixa corresponde aos adolescentes e adultos jovens.

Tabela 2:

Homicídios segundo sexo e idade $\left(\mathrm{n}^{\circ}, \%\right.$ e coeficientes/100.000 habitantes). Município de São Paulo, 2000.

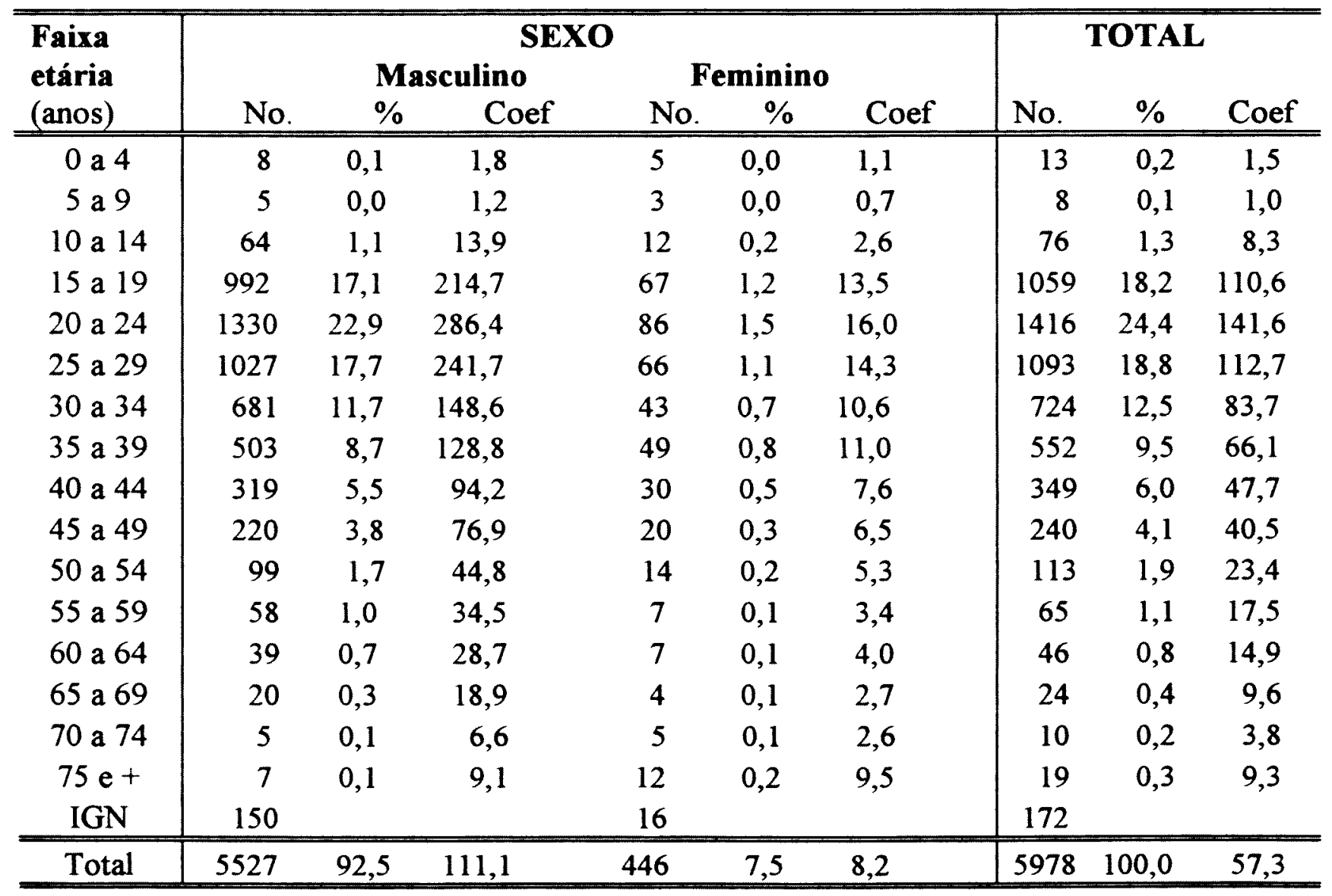

Nota: Percentuais calculados sobre o total de casos com informação conhecida (5 casos tiveram o sexo ignorado). 


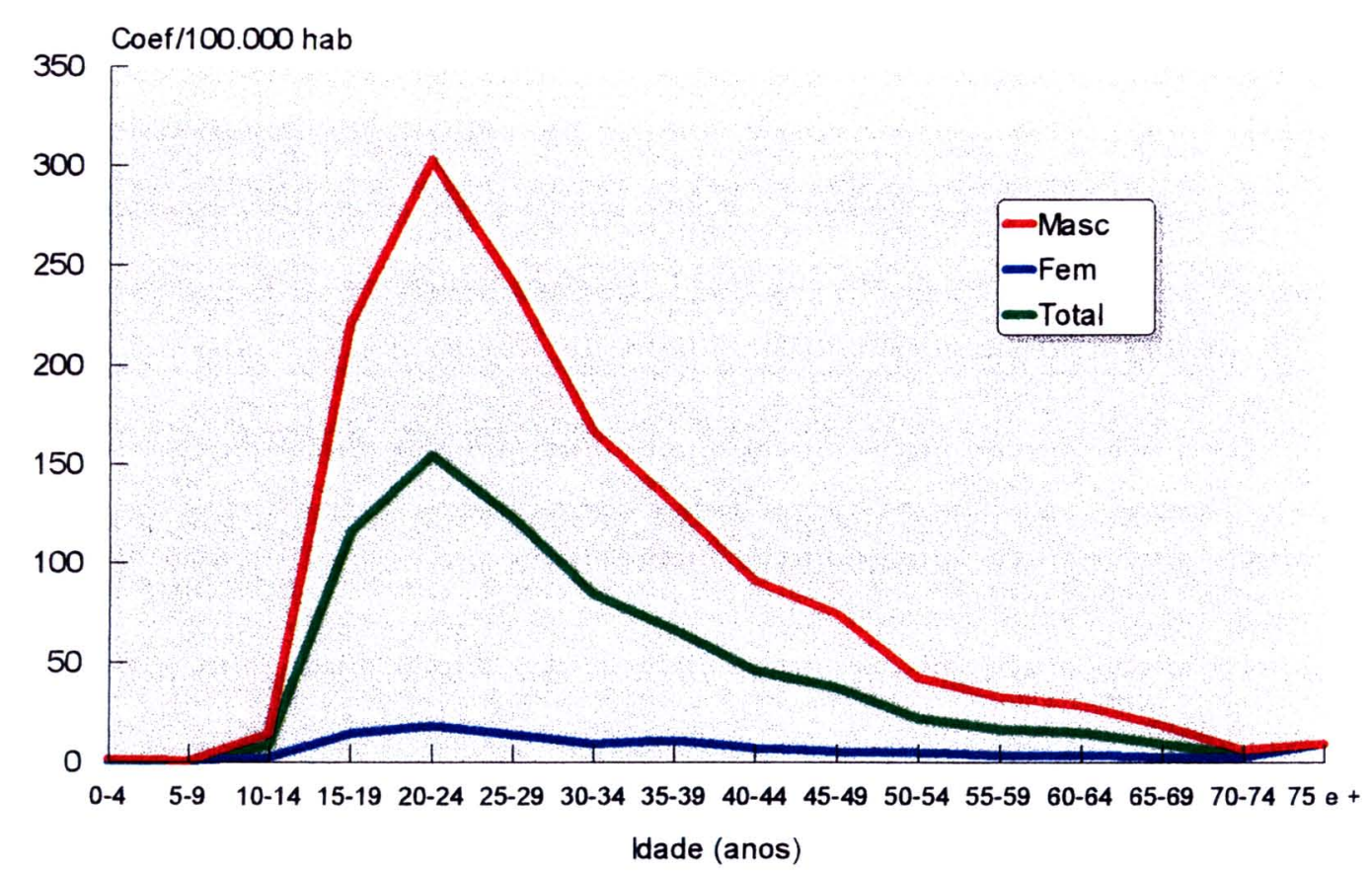

Figura 6 - Coeficientes de mortalidade por homicidios segundo sexo e idade. Município de São Paulo, 2000.

A mulher que morre vítima de homicídio, também é, na maioria dos casos, jovem. O sexo feminino apresenta os coeficientes e as proporções distribuídos de maneira similar àquela encontrada para o sexo masculino: crescendo abruptamente na idade dos 15 aos 19 anos, atingindo o seu pico na faixa dos 20 aos 24 anos, mantendo valores elevados até os 39 anos, tendendo depois a decrescer com o avançar da idade. No entanto, os coeficientes entre as mulheres são muito menores do que o dos homens, como já ressaltado.

Em relação à questão do jovem, é fato que as mortes pelo conjunto das causas externas atingem preferencialmente esta faixa; no entanto, essa tendência é mais pronunciada para os homicídios do que para qualquer outra dessas causas. Para ilustrar essa afirmativa, a Figura 7 mostra os coeficientes médios de mortalidade encontrados para o biênio 1999-2000, para o total das causas externas, homicídios, acidentes de transporte e suicídios. Optou-se por 
analisar os últimos dois anos em conjunto, com o propósito de diminuir as pequenas variações que ocorrem nesses coeficientes de um ano para outro.

Certamente, o formato da curva para o total de causas externas sofre forte influência do peso dos homicídios, mas apresenta também coeficientes altos nas faixas etárias mais velhas. Isso se deve ao fato de que essas idades apresentam risco aumentado para as quedas acidentais, suicídios e também para os acidentes de transporte. E, além disso, as faixas mais jovens não apresentam um pico tão marcante para esses tipos de causas como o visto para os homicídios.

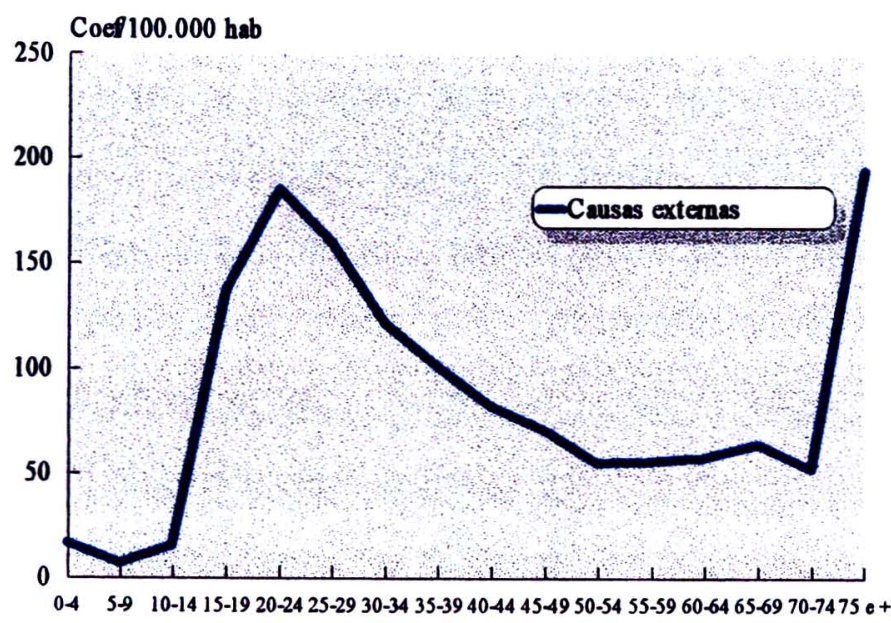

Idade (anos)
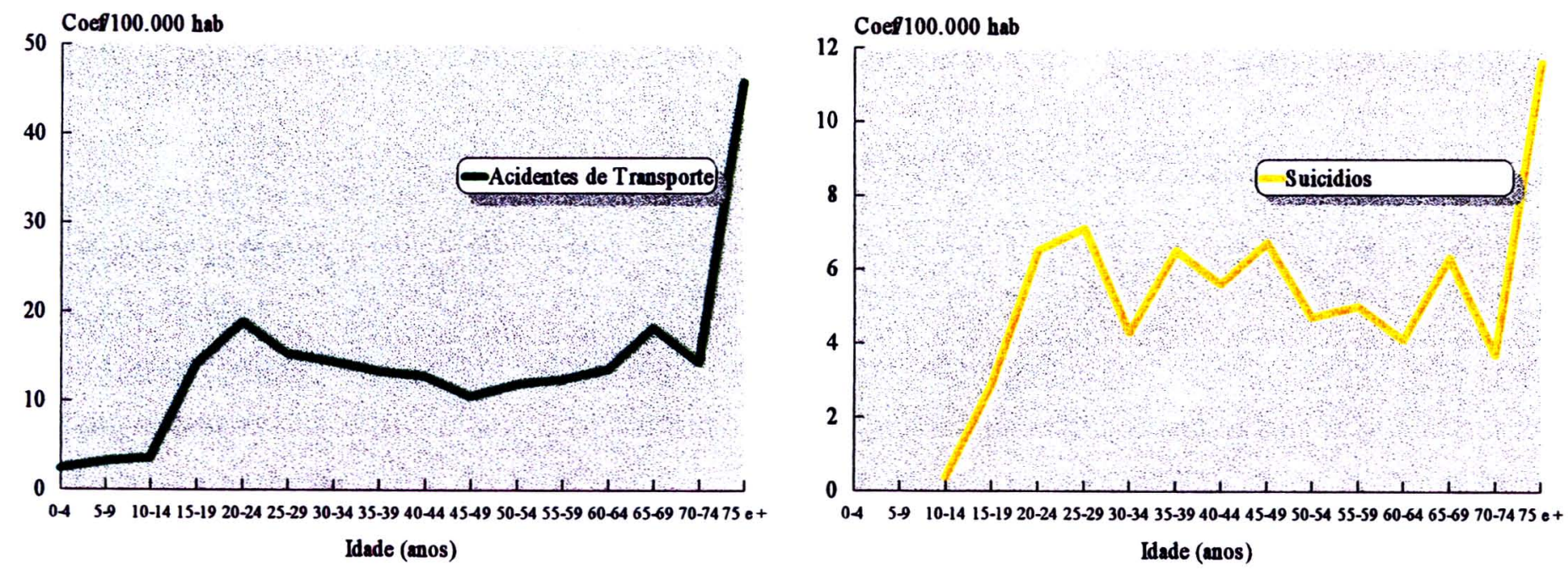

Figura 7: Coeficientes de mortalidade médio por causas externas, homicidios, acidentes de transporte e suicidios, segundo faixas etárias.

Municipio de S. Paulo, 1999-2000. 
A cidade de Los Angeles é considerada, nos EUA, um local que exibe altos índices de homicidios, provavelmente relacionados à existência de gangues. O coeficiente de mortalidade por homicídios para o ano de 1996, para a população geral foi $14,0 / 100.000$. No entanto, quando se considera o grupo afro-americano do sexo masculino com idade entre 15 a 34 anos, essa taxa chega a 164,2/100.000 (Demetriades e col., 1998). Nota-se que esses indices são bem menores que os observados nos homens residentes na cidade de S. Paulo, nesta mesma faixa etária, que alcança 222,7/100.000.

Seria ideal poder comparar as taxas do Município de São Paulo com as observadas em outras cidades do mesmo porte. No entanto, a pesquisa na literatura não permitiu isso. Ainda assim, a comparação com coeficientes de paises da região das Américas, incluindo o Brasil (Yunes \& Zubarev, 1999), para o sexo masculino e idade de 15 a 24 anos e com os valores observados para o município, já dá uma idéia do quão dramático é este problema em nosso meio (tabela 3). A Capital de São Paulo, supera até mesmo as taxas da Colômbia.

Tabela 3:

Homicidios no sexo masculino, idades de 15 a 24 anos (coef/100.000). Paises das Américas

\begin{tabular}{lc}
\hline País & Coeficiente \\
\hline Brasil (1995)* & 74,2 \\
Canadá (1995)* & 3,1 \\
Estados Unidos $(1997)^{\star}$ & 28,8 \\
Argentina (1996)* & 11,0 \\
México (1995)* & 38,6 \\
Colômbia (1995)* & 199,6 \\
Cuba (1996)* & 16,1 \\
São Paulo (2000)** & 250,6
\end{tabular}

Fonte: * Yunes (1999)

** PRO-AIM (dados brutos) 
- Os homicidios segundo o meio utilizado

A análise dos homicídios segundo o meio utilizado foi realizada a partir dos registros da Declaração de Óbito (Tabela 4), Boletim de Ocorrência e laudo de necropsia (Tabela 5), em que é possivel comparar as três fontes de dados.

A partir das DOs, observa-se, que as armas de fogo causaram a maior parte dessas mortes: $58,3 \%$ para os homens e $50,9 \%$ para as mulheres. Embora esse percentual encontre-se distante da realidade, é preciso assinalar que já representam um importante progresso na qualidade do preenchimento da DO, visto que dados para o ano de 1991 (Gawryszewski, 1995) mostravam que os homicídios por armas de fogo representaram $25,6 \%$, enquanto aqueles por meios não especificados eram a maioria, com um percentual de $72 \%$. Apesar desse avanço, a proporção de meios não especificados ainda apresenta-se alta $(38,4 \%)$, desnecessariamente.

Tabela 4

Homicídios segundo sexo e o meio utilizado.

Município de São Paulo, 2000.

\begin{tabular}{lcccccc}
\hline \multirow{2}{*}{ Meio utilizado } & \multicolumn{2}{c}{ Masculino } & \multicolumn{2}{c}{ Feminino } & \multicolumn{2}{c}{ Total } \\
\cline { 2 - 7 } & No & $\%$ & No. & $\%$ & No & $\%$ \\
\hline Arma de fogo & 3223 & 58,3 & 227 & 50,9 & 3451 & 57,7 \\
Objeto cortante e penetrante & 153 & 2,7 & 28 & 6,2 & 181 & 3,0 \\
Objeto contundente & 17 & 0,3 & 2 & 0,4 & 19 & 0,3 \\
Outros & 18 & 0,3 & 8 & 1,8 & 28 & 0,6 \\
Ignorado & 2116 & 38,4 & 181 & 40,7 & 2299 & 38,4 \\
\hline Total & 5527 & 100,0 & 446 & 100,0 & 5978 & 100,0 \\
\hline \hline
\end{tabular}


A partir dos registros nos $\mathrm{BO}$, os percentuais correspondentes às armas de fogo sobem para 69\%. Ainda assim, não é possivel conhecer a real participação desse meio na perpetração dos homicidios, visto que a categoria dos ignorados soma $22,1 \%$ do total.

Já com os dados do IML, considerada a fonte realmente fidedigna ("padrão ouro") para essa variável, verificou-se que as armas de fogo foram o meio utilizado para a perpetração de 90,1\% dessas mortes. Este achado é coerente com alguns levantamentos realizados pela Polícia Civil do Estado de São Paulo (DHPP, 1998), visto que, em relação a crimes de autoria desconhecida para o ano de 1998, a participação das armas de fogo, chega a $90 \%$ (em 1997, foi $86 \%$ ). Os meios não especificados, reduzem-se a somente três casos $(0,2 \%)$, correspondendo a corpos encontrados já em estado de putrefação. Esses achados confirmam a hipótese de Mello Jorge (1999) de que o IML dispõe da informação completa, apesar de não a transcrever na DO. Provavelmente, isso deve ser verdadeiro para todo Brasil, pois Souza (1994), ao analisar os dados de mortes por armas de fogo para algumas capitais brasileiras, para os anos de 1980 e 1989, também encontrou percentuais baixos.

Tabela 5:

Homicídios segundo o meio utilizado (no. e \%), nas várias fontes. Município de São Paulo, abril a junho de 2000.

\begin{tabular}{l|rc|rc|rr}
\hline \multicolumn{1}{c|}{ Meio utilizado } & \multicolumn{2}{|c|}{ DO } & \multicolumn{2}{c|}{ BO } & \multicolumn{2}{c}{ IML } \\
& No. & \multicolumn{1}{c}{$\%$} & No. & \multicolumn{1}{c}{$\%$} & No. & $\%$ \\
\hline Arma de fogo & 3451 & 57,7 & 906 & 69,0 & 1247 & 90,1 \\
Objeto cortante e penetrante & 181 & 6,2 & 88 & 6,7 & 60 & 4,3 \\
Objeto contundente & 19 & 0,3 & 14 & 1,1 & 54 & 3,9 \\
Outros & 28 & 0,6 & 14 & 1,1 & 20 & 1,4 \\
Ignorado & 2299 & 38,4 & 291 & 22,1 & 3 & 0,2 \\
\hline Total & 5978 & 100,0 & 1313 & 100,0 & 1384 & 100,0 \\
\hline
\end{tabular}


As armas brancas participam com $4,3 \%$ do total e os objetos contundentes, entre os quais encontram-se os espancamentos, embora os números absolutos sejam pequenos, aumentam o seu percentual em relação às outras fontes, chegando a $3,9 \%$.

Trata-se de um fenômeno mais amplo, devendo atingir outras capitais brasileiras, pois também no Recife, as armas de fogo foram responsáveis por $97 \%$ das mortes por homicídios em menores de 20 anos, no ano de 1997 (Falbo e col, 2001). A questão da larga utilização e facilidade de aquisição de armas de fogo inquieta toda a sociedade. Os noticiários das redes de comunicação falam a respeito da utilização e, algumas vezes, apreensão de armamentos pesados, utilizados pela rede de criminalidade, alguns deles referidos como de uso exclusivo das Forças Armadas, deixando uma sensação de angústia entre os cidadãos.

Tal sentimento não é infundado, pois as armas de fogo são fortes aliadas do aumento da violência (tanto nos homicídios, quanto nos suicidios), não somente na sociedade brasileira, mas internacionalmente. Os Estados Unidos são o país que mais estuda o papel das armas de fogo entre as violências, visto que a posse de arma é um direito garantido na Constituição Americana. Além disso, é algo aceito culturalmente, arraigado, remetendo à própria Revolução Americana, que contou com a participação de pequenos fazendeiros, artesãos e burgueses, cada qual com a sua espingarda, se rebelando contra o soberano.

As estimativas do número de armas de fogo existentes naquele país são realmente alarmantes, pois há aproximadamente 200 milhões de armas de fogo em posse de pessoas privadas e 1 milhão de armas semi-automáticas, capazes de dar vários tiros seguidos e ferir ou matar muitas pessoas em curto espaço de tempo (American Medical Association, 1992). Atualmente, a sociedade norte-americana, e dentro dela, a área da saúde ligada à prevenção, vem realizando toda uma discussão em direção a um maior controle da posse e uso de armas, com forte oposição de setores da sociedade americana. 
Os Estados Unidos, desde a década de 80 , tem Sistemas de Vigilância para Lesões por Armas de Fogo (sejam acidentais ou intencionais) implantados em vários Estados (Mercy e col., 1998). Dados para o ano de 1995 mostraram que as armas de fogo foram responsáveis por $69 \%$ do total de homicidios e 59\% dos suicídios, ocorridos nos Estados Unidos da América. Chega a ser estranho comparar estes dados com os encontrados para o Município de São Paulo, visto que, a despeito da reconhecida questão cultural que envolve a posse de armas na sociedade americana, esses percentuais são menores, revelando que as armas de fogo no Brasil, são um problema ainda mais grave e que a sociedade brasileira e a própria área da saúde conhecem e discutem ainda muito pouco esta questão.

E esse não é um problema recente; Yunes (2001) cita trabalho realizado a partir da análise dos registros de necropsias do IML de São Paulo, no periodo de 1965 a 1989, no qual é confirmado que os homicídios causados por armas de fogo aumentaram a ritmo constante e progressivo até o final da década de 70 , quando se inicia um aumento significativo até o final da década de 80. Isso significa que o alarmante crescimento dos homicídios, verificado nesta década no Município, foi possibilitado pelo uso de armas de fogo.

Esse fato fica bem ilustrado na Figura 8, que apresenta a série histórica, construída a partir de dados de Mello Jorge (1979 e 1982) e Gawryszewski (1995), cujos estudos também utilizaram metodologia de pesquisa aos laudos do IML. Aqui, é possivel observar que a variação do percentual de utilização das armas de fogo entre as mortes por homicídios acompanha o crescimento dos coeficientes de mortalidade, entre o início da série e o momento atual. Em 1960 , esse tipo de arma foi responsável por apenas $28,4 \%$ do total das mortes por homicídios, enquanto em 2000 , já responde por $90,1 \%$.

É preciso lembrar que a maior facilidade de acesso às armas de fogo, realmente, tem o poder de impulsionar o número de mortes por homicídios, visto a alta letalidade desse meio, determinando menores chances de defesa ou fuga para as vítimas quando comparadas, por exemplo, com as armas brancas. No entanto, arma de fogo é somente um meio para a perpetração do 
crime, pois outros fatores devem estar envolvidos. Costa MR (1999) aponta que as altas taxas de homicídios nos Estados Unidos não devem ser única e exclusivamente atribuídas à maior liberdade de acesso às armas de fogo, pois, em Israel e na Suíça, onde a população também tem acesso a esse tipo de armas, os níveis de homicídio não se comparam com os daquele país. Com certeza, outros elementos devem ser agregados para essas ocorrências. llustra essa afirmativa um interessante estudo conduzido nos Estados Unidos para os anos de 1996 e 1999 por Hemenway e col. (2000) sobre a utilização de armas entre a população americana, que concluiu que as armas são usadas para ameaçar e intimidar, muito mais que para defesa própria.

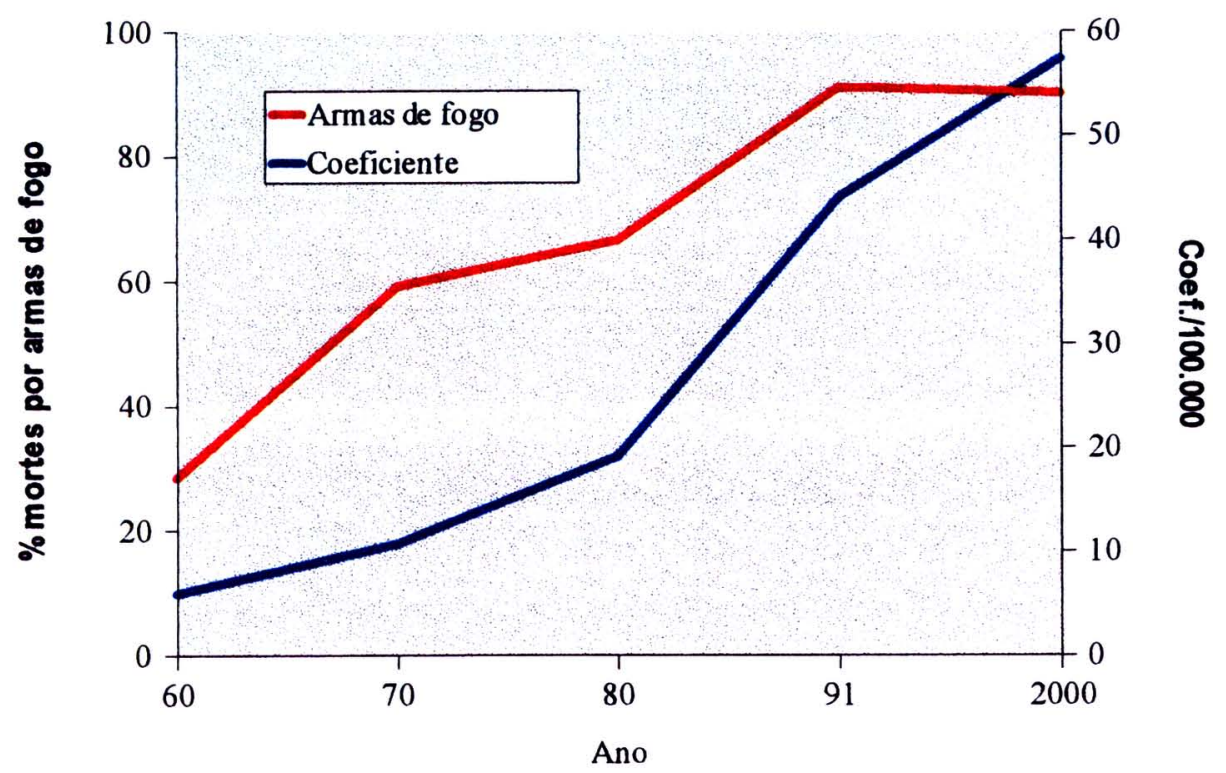

Fonte: Mello Jorge (1979 e 1982), Gawryszewski (1995), Gawrysewski e Mello Jorge (2000)

Figura 8 - Distribuição temporal dos coeficientes de mortalidade por homicidios e utilização de arma de fogo (\%). Municipio de S. Paulo, 60, 70, 80, 91 e 2000

Quando são realizados cruzamentos das informações obtidas acerca do meio utilizado com faixa etária (ressalva-se que o pequeno número de casos para os outros meios traz limitações à análise), observa-se que as armas de fogo assumem ainda maior preponderância para as faixas etárias mais jovens (Figura 9), entre 15 e 24 anos, faixa em que o pico da freqüência de mortes 
provocadas pelas armas de fogo, cujo percentual chega a 96,2\%. Há um declínio ligeiro com o avançar da idade. Foram excluídos 44 casos com idade ignorada, entre os quais, a proporção de utilização das armas de fogo foi menor que a média $(61,4 \%)$ e a proporção de mortes por objeto contundente/espancamentos chega a $11,4 \%$.

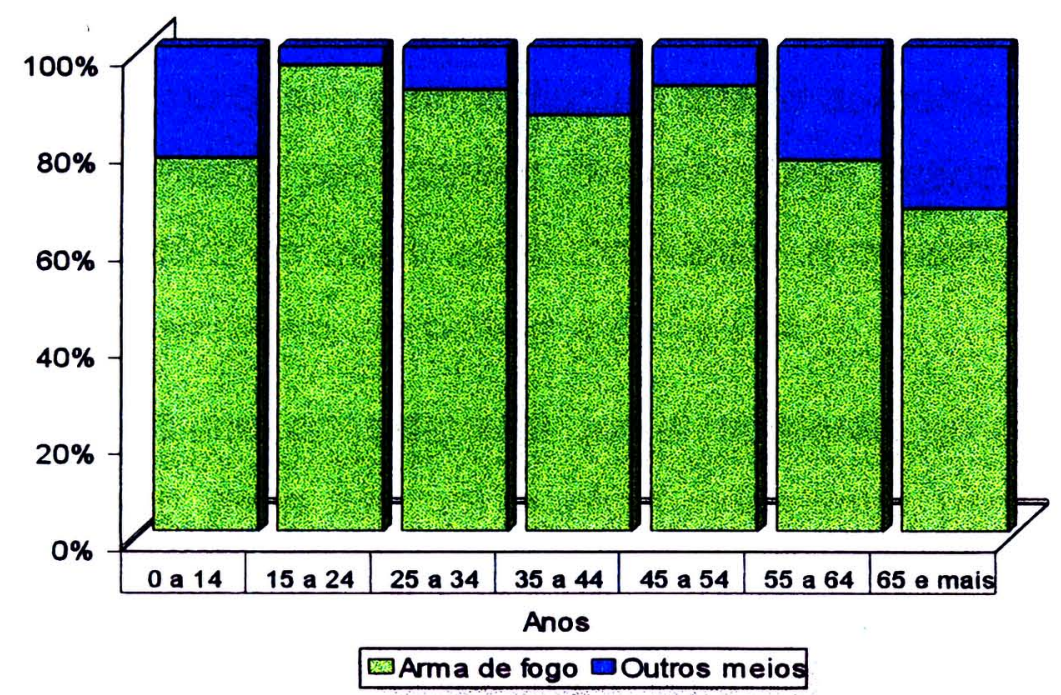

Figura 9:

Homicidios segundo idade e meio utilizado. Município de São Paulo, abril, maio e junho, 2000.

Os resultados do sistema de vigilanncia por armas de fogo implantado na cidade de Nova York são coincidentes com os obtidos nesta pesquisa, pois na faixa de 15 a 24 anos as mortes por este tipo de arma preponderam. Os outros tipos foram mais utilizados nas faixas maiores e em lesões não fatais (Wilt \& Gabrel, 1998).

Esta grave situação pode ser ampliada para todo o país. Szwarcwald \& Leal (1998) demonstraram que, entre jovens brasileiros de 15 a 19 anos, as taxas de mortalidade por armas de fogo cresceram a uma velocidade de $9 \%$ ao ano no período de 1980-1995, chamando atenção para o fato de que, 
coincidentemente, trata-se da mesma coorte de crianças que sobreviveram à mortalidade infantil, que agora estão morrendo pelas armas de fogo.

Considerando a hipótese de que as mortes relacionadas à criminalidade organizada utilizem-se preferencialmente armas de fogo, enquanto nas mortes resultantes de conflitos e desavenças, os meios mais simples (tais como armas brancas, objetos contundentes), pelos dados aqui levantados, é possivel que as mortes de jovens encontrem-se mais ligadas à criminalidade, enquanto os conflitos envolvam pessoas mais velhas. Reforça tal hipótese um trabalho de Zaluar (1998), no qual a autora discute que "o aumento da circulação de armas de fogo propiciado pelo tráfico puseram nas mãos de jovens pobres os instrumentos com os quais estes passaram a construir novas imagens de si mesmos, do seu bairro, da cidade e do mundo".

Por tudo isto, considera-se que a repressão ao comércio e utilização de armas de fogo deve ser um ponto fundamental para qualquer política de prevenção que venha a ser adotada.

\section{. Uso de substâncias psicoativas}

Os dados apresentados na Tabela 6 dizem respeito ao uso de substâncias psicoativas nas vítimas de homicídios. Os exames são realizados pelo Instituto Médico Legal, somente quando há solicitação das Delegacias Policias responsáveis pela área.

De um total de 1384 laudos examinados, o exame toxicológico não foi solicitado para 774 vítimas $(55,9 \%)$. Entre aquelas que tiveram o exame solicitado, para um pouco mais que a metade $(56,6 \%)$ o resultado foi negativo. O álcool foi a substância mais utilizada entre estas vítimas $(40,9 \%)$. O uso de cocaína sozinha, ou associada ao álcool apresentou percentuais muito baixos $(2,8 \%)$. 
Tabela 6:

Uso de substância psicoativas em vítimas de homicídio $\left(n^{\circ} \mathrm{e} \%\right.$ ). Município de São Paulo, abril a junho de 2000.

\begin{tabular}{l|c|c}
\hline \multicolumn{1}{c|}{ Resultado do exame } & No. & $\%$ \\
\hline Negativo & 345 & 56,6 \\
Álcool & 235 & 38,3 \\
Álcool + Cocaína & 13 & 2,1 \\
Álcool + Cocaína + Lidocaína & 4 & 0,7 \\
Cocaína & 2 & 0,3 \\
lgnorado & 11 & 1,8 \\
\hline Total & 610 & 100,0 \\
\hline
\end{tabular}

Nota: Excluídos os 774 casos que não tiveram o exame não foi solicitado

Fonte: IML (dados brutos)

Uma das limitações desta análise é que esta proporção não deve ser ampliada para o conjunto das vítimas, visto não ser conhecido o critério que norteia essa seleção. Este exame é geralmente solicitado pelo delegado de polícia ou pelo legista. O critério tanto pode ser aleatório quanto pode ter sido indicado na vigência de uma situação de suspeita, o que viciaria a amostra. Apesar disso, este dado não deve estar longe da realidade, visto que Carvalho (2002) encontra proporções ainda maiores, ao estudar a alcoolemia em pacientes atendidos por causas externas, no Pronto-Socorro do Hospital das Clínicas, em São Paulo, no período de agosto de 1998 a agosto de 1999 (a partir de amostra aleatória), observando positividade em $28,9 \%$ dos casos, com a maior prevalência entre as vítimas de agressão $(46,2 \%)$.

Essa alta prevalência de utilização do álcool entre as vítimas de homicídio que tiveram o exame toxicológico solicitado chama atenção para este grave problema, apontando que um maior número de pesquisas deve ser realizado para elucidar o papel do álcool na potencialização dos conflitos sociais que resultam em morte. $O$ ideal seria poder também contar com este exame para o agressor, já que este muitas vezes é quem pode estar sob a influência dessa substância. 
Não se configura como novidade que o uso do álcool encontra-se associado com risco aumentado de comportamentos violentos. $\mathrm{Na}$ literatura internacional são vários os trabalhos que demonstram tal relação, seja nas relações amorosas (Caetano e col., 2000; Logan e col., 2.000) ou intrafamiliares (Rodriguez e col., 2001). Pillmann e col. (2000) referem que a intoxicação aguda por álcool influencia a ocorrência de crimes violentos de uma maneira direta e que a dependência desta droga predispõe à reincidência desses atos. Em 1996, a Universidade de Colorado nos Estados Unidos baniu a venda de bebidas alcoólicas em seus estádios de futebol, fazendo cair drasticamente os registros de incidentes, tais como o número de prisões, assaltos e expulsões do estádio (Bormann \& Stone, 2001).

Mas, por certo o álcool atua como um fator, mas não é a causa das violências. E, por outro lado, deve ser considerado que o indivíduo sob o seu efeito, pelo prejuizo na atenção e capacidade de julgamento, pode apresentar maior vulnerabilidade nas situações de acidentes e violências. Noto (1999) destaca a diferença no padrão de consumo entre homens e mulheres, sendo que as drogas ilícitas são mais consumidas entre os homens e os medicamentos psicotrópicos são os preferidos pelas mulheres. Aponta também a existência de diferenças regionais no consumo: a cocaína concentra-se nas capitais da região Sul e Sudeste, enquanto os medicamentos psicotrópicos têm maior consumo nas capitais do Nordeste do Brasil. O álcool e tabaco têm distribuição mais uniforme no território nacional.

Um levantamento conduzido pelo Centro Brasileiro de Informações sobre Drogas (CEBRID), entre jovens da rede pública estadual de ensino de dez capitais brasileiras, nos anos de 1987, 1989 e 1993, revela comportamentos distintos nos padrōes de consumo segundo gênero: enquanto no sexo masculino destacam-se as drogas "da rua" (maconha, cocaína e inalantes), o feminino consome medicamentos à base de anfetamina e ansiolíticos (Bastos e Carlini-Cotrim, 1998).

Menéndez e Pardo (2001), referem que o próprio efeito do álcool podendo ser diferente segundo o gênero, obedecendo a referências culturais e 
não somente aos efeitos bioquímicos da substância. Os autores discutem que o álcool cumpre um papel facilitador social de todo o tipo de relações (incluidas as sexuais). Para ambos, homens e mulheres, atua como fator desinibidor, reduzindo a responsabilidade e levando a comportamentos não legitimados quando os indivíduos encontram-se sóbrios. No entanto, a desinibição masculina conduz a expectativas de comportamentos que não são as mesmas para as mulheres, constituindo-se num dos mecanismos de identidade e de diferenciação. Além disso, os homens costumam consumir maiores quantidades dessa substância. Já nas relaçōes homossexuais masculinas, o uso de álcool tem efeito diverso, configurando-se como fator de risco para a AIDS e outras doenças sexualmente transmissiveis, pois atua principalmente como facilitador das relaçōes sexuais, limitando o uso de preservativos.

A análise dos resultados do presente estudo, do exame toxicológico (excluidos aqueles cujo exame não foi solicitado) em relação ao sexo, mostrou uma maior proporção de consumo de álcool no sexo masculino, chegando a $41,8 \%$, enquanto nas mulheres foi de $31,4 \%$ (ressalva-se que é pequeno número de casos entre mulheres, o que limita a análise). No estudo realizado no Pronto-Socorro do Hospital das Clínicas, citado anteriormente (Carvalho, 2002), o sexo masculino também apresentou maior prevalência de alcoolemia positiva, $33,9 \%$.

Em relação às faixas etárias, para as vítimas de homicídios que tiveram o exame toxicológico realizado pelo IML, observa-se que nas idades mais jovens e mais velhas, o percentual de resultados positivos para álcool é menor que a proporção média. Porém, nessas faixas tanto o número absoluto de vítimas quanto o percentual de exames solicitados são menores, sendo que nenhum exame foi solicitado para as vitimas menores de 10 anos. Na ampla faixa que vai de 20 a 54 anos, praticamente metade das vítimas tinha ingerido álcool na ocasião do óbito (Figura 10). Da mesma forma, o trabalho de Carvalho (2002) em pacientes em serviço de emergência verificou maior prevalência na faixa dos 25 aos 44 anos, 37,6\% (Carvalho, 2002). 
O consumo de álcool entre os jovens vem crescendo, tanto a experimentação, como o relato de consumo recente, em várias capitais do país, acentuando-se rapidamente a partir de 1995. Novamente, o Brasil encontra-se em rota inversa aos países industrializados europeus e da América do Norte, nos quais o consumo de álcool vem diminuindo ou mantendo-se estável (Bastos e Carlini-Cotrim, 1998). Yunes (2001) refere ser o Brasil o sexto produtor mundial de cerveja, tendo sido consumida uma média de trinta e cinco litros por pessoa, para o ano de 1993, enquanto o consumo de leite foi de somente vinte litros por pessoa/ano. Associando-se a isso, a sociedade brasileira apresenta grande tolerância em relação à comercialização de bebidas, contando com pouca regulamentação, que é freqüentemente desrespeitada, como é o caso da proibição da venda para menores de dezoito anos.
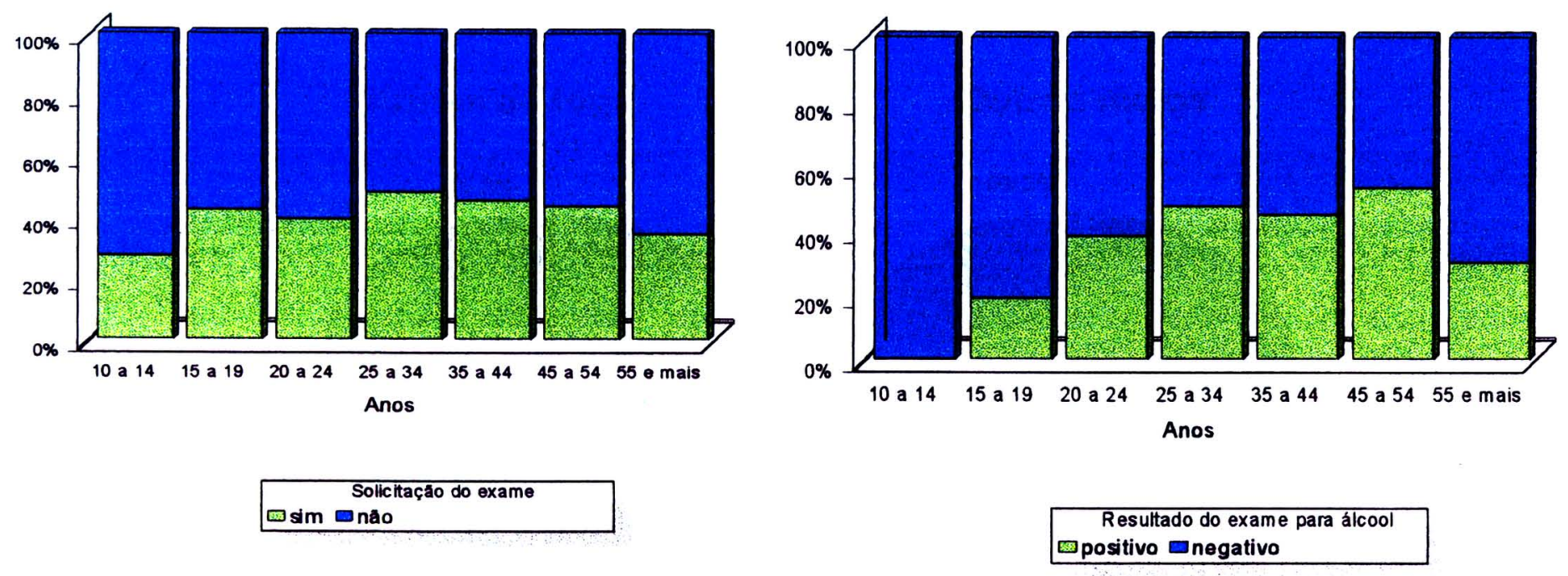

Obs: Excluídos 44 casos com idade ignorada

Figura 10: Homicídios segundo a solicitação do exame e resultado positivo para álcool pela vítima segundo idades. Município de São Paulo, abril, maio e junho, 2000.

O estudo do conjunto dos dados a respeito de consumo de álcool (excluídos aqueles cujo exame não foi solicitado) com o meio utilizado para a 
perpetração dos homicídios também mostrou a existência de algumas diferenças. Entre aqueles cometidos por arma de fogo, 35,8\% das vítimas tinham feito uso de álcool, enquanto para os perpetrados por outros meios (arma branca, objeto contundente etc), esse percentual é maior, chegando a $56,2 \%$. Isso reforça a hipótese de que esses últimos crimes possam estar mais relacionados à inadequada resolução de conflitos, potencializados pelo uso do álcool (Figura 11), enquanto os eventos relacionados com o crime organizado devem utilizar mais as armas de fogo.

Variações, em relação ao uso do álcool, foram observadas não somente em relação ao sexo, idade e meio utilizado para perpetração dos homicídios, mas também quanto ao tipo de local em que ocorreu o ato violento e ao horário do dia, o que será visto mais adiante.

Armas de fogo

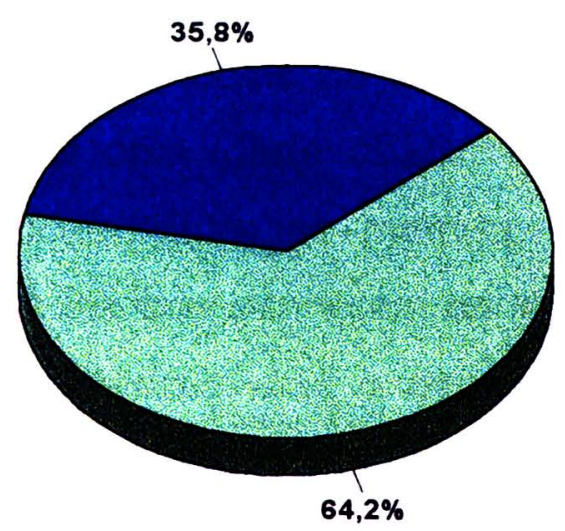

\section{Outros meios}

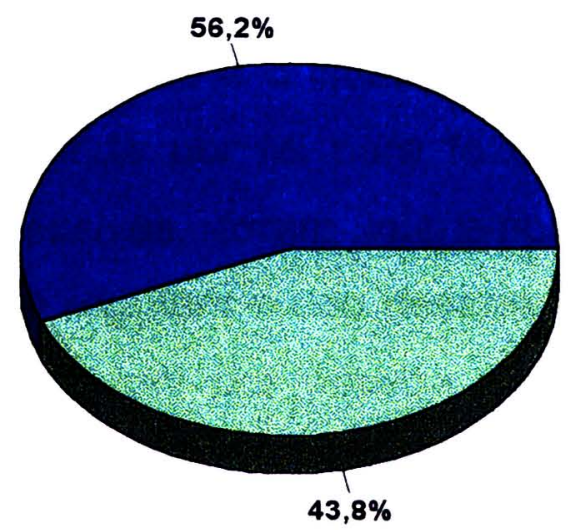

Resultado de exame para alcool $\square$ Positivo Negativo

Obs: Excluídos os casos cujo exame toxicológico não foi solicitado

Figura 11 - Homicídios segundo o meio utilizado e uso de álcool pela vítima. Município de São Paulo, abril a junho de 2000. 
É sabido que esta substância é fator de risco também para os outros tipos de violências. A Associação Brasileira dos Departamentos de Trânsito (Abdetran, 1997), realizou uma pesquisa em quatro capitais brasileiras (Salvador, Recife, Brasília e Curitiba), tendo detectado que em $27,2 \%$ das vítimas envolvidas nesse tipo de acidentes, a dosagem de álcool no sangue excedia o valor permitido por lei, $0,6 \mathrm{~g} / \mathrm{l}$. Entre as drogas ilícitas encontradas, destacou-se a maconha $(7,7 \%)$, os benzodiazepínicos $(3,4 \%)$ e a cocaina (2,3\%). Também no Município de São Paulo, o consumo de álcool mostra-se importante, pois trabalho realizado pelo IML revelou que o número de vítimas fatais nos acidentes de transporte, envolvendo condutores alcoolizados ou pedestres atropelados bêbados é cerca de $50 \%$ (CET, 2001).

Um estudo conduzido na Califórnia (Holder, 2000), revelou bem o efeito do álcool sobre os atos violentos. O objetivo era determinar o efeito de intervenções no ambiente na redução das altas taxas de acidentes de carro e agressōes, ligadas ao consumo de álcool. O estudo foi realizado entre 1992 e 1996. As intervenções englobaram ações educativas e repressivas. Entre as primeiras, encontra-se a mobilização da comunidade, o encorajamento da responsabilidade nos locais de comércio de bebidas e o limite do acesso ao álcool por jovens com idade abaixo da permitida por lei para fazer uso de bebidas alcoólicas. Entre as medidas repressivas, foram intensificadas as prisōes de pessoas que infringiam as leis que regulam o uso dessas bebidas. Os resultados revelaram que o consumo de álcool por pessoa declinou no período, bem como a freqüência de uso excessivo da substảncia $(49 \%)$ e também 0 ato de dirigir sob o efeito do álcool $(51 \%)$. Resultados a partir das informações das emergências foram comparados com comunidades onde não houve implantação de qualquer medida, tendo mostrado que os acidentes de trânsito declinaram $10 \%$ e as agressões $43 \%$, nas comunidades com intervenção. 


\section{- Localização anatômica das lesóes}

Nas mortes violentas, se a causa básica é uma informação fundamental para a orientação de medidas preventivas, o conhecimento da natureza da lesão é igualmente importante para orientar o planejamento e organização dos serviços de saúde, que devem alocar recursos e profissionais para o atendimento das vitimas para as quais a prevenção não logrou êxito. É por meio dos laudos de necropsia que se espera obter este dado, podendo ser considerado realmente fidedigno. Nesta pesquisa, foram encontrados muitos BO que continham descrição de ferimentos, tanto por arma de fogo, quanto por arma branca, especialmente aqueles investigados pelo DHPP.

Devido ao percentual elevado de mortes decorrentes de armas de fogo, optou-se por apresentar somente os dados referentes às lesões produzidas por esse tipo de arma. Além disso, dado que fica difícil saber, dentre todas as lesões descritas qual a que levou à morte, optou-se por apresentar a localização anatômica das lesões e não com a natureza da lesão propriamente dita.

A média de projéteis por vítima foi 4,1. É importante salientar que a intenção de produzir a morte fica evidente ao se verificar que a cabeça foi o alvo mais freqüente, concentrando $29,9 \%$ de todos os ferimentos verificados (Figura 12), apresentando uma média de 2,8 projéteis por vítima, entre aquelas que foram atingidas na cabeça. Sabe-se que os traumas cranianos determinam mortalidade alta, mesmo em situaçăo de serviço de saúde especializado.

Logo depois, segue-se o tórax, respondendo por $20 \%$ das lesōes, cuja média de tiros foi 1,8. Em terceiro lugar, encontra-se a região dorsal, o que pressupōe que a vitima fugia dos agressores ou encontrava-se já caída (concentrou $17,6 \%$ do total de lesões, com uma média de projéteis de 1,9 ). Segue-se uma região pouco letal representada pelos membros superiores, com 15,4\%, apresentando uma média de 1,9. 0 abdome e quadril 
concentraram $10,9 \%$ dos ferimentos, com média de 1,8 tiros e, por último, ficaram os membros inferiores com $6,2 \%$, o que dá uma média de 1,9 tiros.

A $18^{\mathrm{a}}$ Jornada Paulista de Cirurgia Plástica, realizada em 1998, revelou que as seqüelas de queimaduras que, tradicionalmente, eram o principal motivo para procura por cirurgias reparadoras, estão sendo atualmente substituídas pelas fraturas de malares e ferimentos provocados por golpes de faca e tiros. A maioria das lesões ocorreu nas regiões do rosto e tórax (Colégio Brasileiro de Cirurgiōes, 1999), coincidindo com os mesmos segmentos corporais encontrados no presente trabalho.

Um estudo realizado em serviço de emergência na Espanha, com vítimas de acidentes violentos (Nunez e col, 2000), verificou que os homens, além de representarem a maioria desses atendimentos $(70 \%)$, também tinham ferimentos mais graves que as mulheres. A região da cabeça-pescoço foi a localização anatômica com maior número de lesões severas (42\%), seguidas dos membros superiores (26\%).

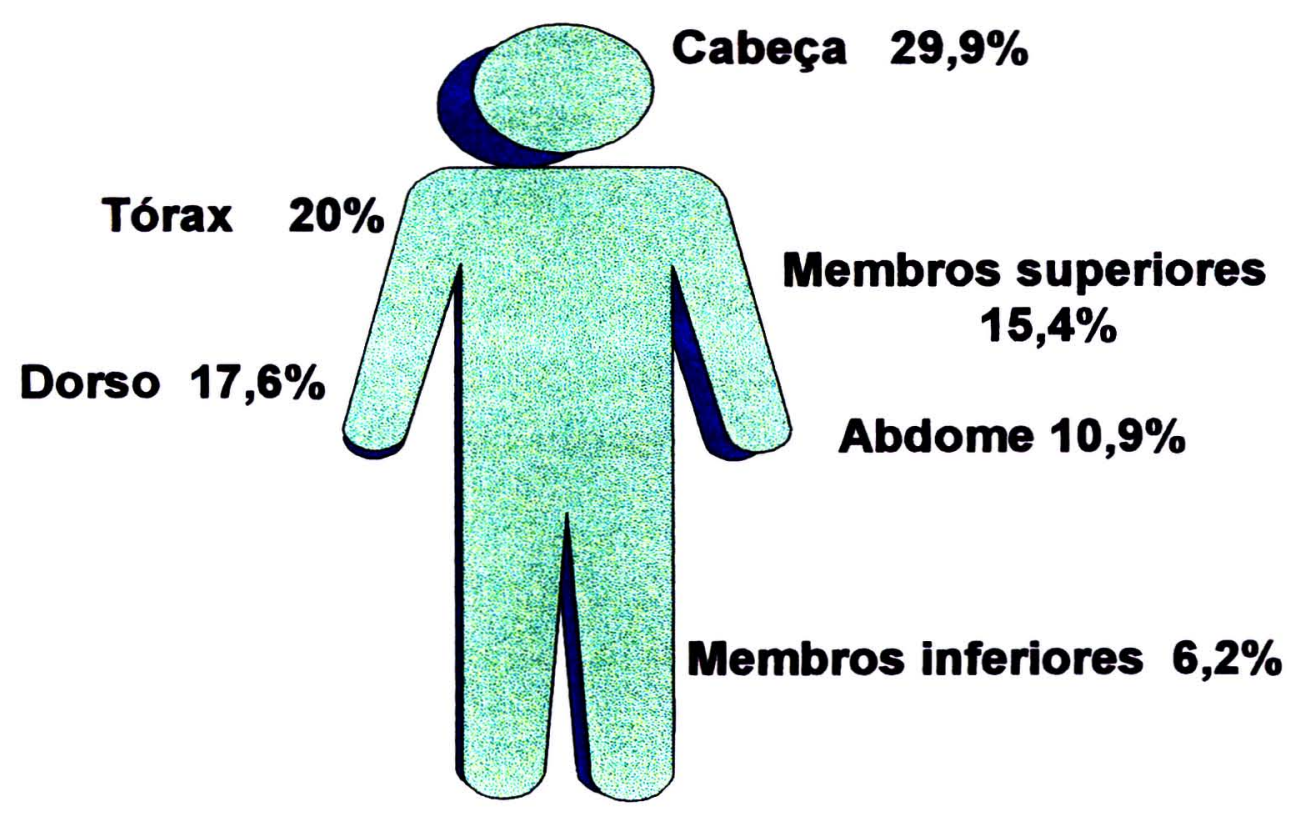

Figura 12 - Homicídios por armas de fogo, segundo localização anatômica da lesão. Municipio de São Paulo, abril a junho de 2000. 
Por certo, esses dados permitem outras formas de análise, aqui o denominador foi o total de ferimentos e o numerador os segmentos corpóreos. Aponta-se a necessidade de discutir acerca da questão das causas múltiplas de morte para esses casos.

Nos Estados Unidos foi desenvolvido, em fins da década de 70 , um programa visando qualificar médicos para o atendimento ao paciente vítima de trauma, o ATLS (Advanced Trauma Life Support). No Brasil, o programa já existe desde 1987 e conta atualmente com o apoio do Ministério da Saúde, além das associações médicas dos cirurgiōes e dos ortopedistas, tendo já sido realizados vários treinamentos por todo país. Dados acerca da natureza da lesão poderiam subsidiar estes treinamentos, aumentando sua efetividade. Seria importante que estas sociedades pudessem ter acesso a este tipo de informação produzida regularmente.

Comparando esses dados com informações obtidas para o ano de 1991 (Gawryszewski, 1995), em estudo para os menores de 20 anos, é possivel perceber o que alguns autores, como Adorno e col. (1999), vêm discutindo, ou seja, que os atos violentos de hoje são mais letais. Em 1991, os ferimentos na cabeça contribuiam com menor número, pois representaram $18,15 \%$ do total de lesōes. Foram os traumatismos intra-torácicos que lideraram estes ferimentos, perfazendo $28,5 \%$ do total.

\subsection{As circunstâncias do ato violento}

\section{- Típo de local onde ocorrew or ato violento}

A Tabela 7 mostra a distribuição dessas mortes segundo tipo de local em que ocorreu o fato, em números absolutos e proporções. Esta informação só pode ser obtida a partir dos Boletins de Ocorrência. 
A escolha das categorias obedeceu a critérios específicos. Alguns desses locais foram escolhidos naturalmente, tais como "via pública" e "residência". A categoria "bar" foi individualizada, na busca de quantificar os crimes relacionados com conflitos, ingestão de bebidas alcoólicas e lazer. Já o "estabelecimento comercial" teve o sentido de identificar os latrocínios. Considerou-se importante identificar os óbitos ocorridos no interior do "carro", pois informaçōes anteriores vinculavam esse tipo de crime às chamadas "execuçōes", onde as pessoas são mortas subitamente sem chance de defesa, sem qualquer discussão prévia, geralmente por indivíduos que chegam em outro carro ou em motocicletas.

Uma limitação apresentada é que alguns desses óbitos podem ter ocorrido em outro local, porém considera-se que deva corresponder a minoria dos casos.

Tabela 7:

Homicídios segundo o tipo de local em que ocorreu o evento ( $n^{\circ} \mathrm{e} \%$ ). Município de São Paulo, abril a junho de 2000.

\begin{tabular}{|c|c|c|}
\hline Local do evento & No. & $\%$ \\
\hline Via pública & 904 & 68,8 \\
\hline Residência & 130 & 9,9 \\
\hline Bar & 56 & 4,3 \\
\hline Estabelecimento comercial & 62 & 4,7 \\
\hline Carro & 50 & 3,8 \\
\hline Local abandonado (matagal, rio etc) & 48 & 3,7 \\
\hline Cadeia ou penitenciária & 7 & 0,5 \\
\hline Outros & 34 & 2,6 \\
\hline Ignorado & 22 & 1,7 \\
\hline Total & 1313 & 100,0 \\
\hline
\end{tabular}

Fonte: Boletins de Ocorrência Policial (dados brutos)

No presente trabalho, a maior parte dos homicidios ocorreu na via pública, $68,8 \%$. As residências, onde se pensou, inicialmente, que seriam encontrados os crimes passionais e/ou intrafamiliares, participaram com 9,9\% 
do total. As mortes em estabelecimentos comerciais responderam por $4,7 \%$ do total, de um modo geral decorrentes de latrocínios. Na categoria "outros" se encontram, por exemplo, eventos ocorridos dentro de ônibus e lotação. A existência de tipo de local classificado como ignorado deve-se à auséncia dessa anotação no campo "histórico do BO", visto que o endereço do evento consta em $100 \%$ dos documentos.

Um estudo realizado em serviço de emergência na Espanha, com vítimas de acidentes violentos, mostrou que $75 \%$ do total desses acidentes ocorreram em locais públicos, $20 \%$ foram domésticos e $5 \%$ eram ignorados (Nunez e col, 2000), dados semelhantes ao presente estudo.

Quando se relaciona uso de álcool com o tipo de local onde ocorreu o óbito verifica-se um resultado interessante. 0 percentual de uso dessa substáncia entre o total de vítimas (excluídas aquelas cujo exame não foi solicitado) chegou a $38,3 \%$, porém, entre aquelas que se encontravam em bares no momento do ato violento, esta taxa sobe para $78 \%$. Percentuais altos também são encontrados para aqueles que estavam em via pública (45\%) e para os encontrados em locais abandonados $(50 \%)$. Já entre os crimes ocorridos em residéncias, o percentual é menor que a média, $29,1 \%$.

O estudo desta variável assume grande importância no planejamento de medidas preventivas, visto que indica os locais de maior risco. $O$ aumento da agressividade relacionado ao uso do álcool é parte do conhecimento empírico da população. Isso faz com que os bares sejam os locais preferenciais de medidas preventivas, mesmo sem a existéncia de bases científicas para elas. No Município de Săo Paulo há um Projeto de Lei que prevè o fechamento de bares, depois de determinado horário da noite, o que provocou polêmicas. Entre as medidas que o epidemiologista Rodrigo Guerreiro implantou, quando prefeito de Cáli, Colómbia, para reduçăo da morbimortalidade por violéncias, encontrava-se o fechamento dos bares após horário noturno previamente fixado.

\footnotetext{
${ }^{6}$ Informacăo pessoal.
} 
No Município de São Paulo, entre 1960 e 1975, a maior parte dos homicídios ocorria nas residéncias (Mello Jorge, 1979), o que faz a autora levantar a hipótese desses crimes estarem relacionados com conflitos entre amigos e parentes, embora já chamando a atenção que no final do período, 1975, que a proporçăo de mortes ocorridas em residências era menor enquanto a da via pública encontrava-se em ascensão. A partir de 1980 (Mello Jorge, 1982), esta situação se inverte, quando a via pública, então, toma a liderança. Em 2000, além disso, verifica-se que o percentual de homicidios ocorridos em residências apresenta diminuição.

Cabe lembrar que o percentual de utilizaçăo de armas de fogo nestes crimes começa a aumentar na década de 70 e esse aumento se intensifica na década de 80 (ver Figura 8). A análise conjunta dessas variáveis é mostrada na Figura 13. É possível observar que, partir da década de 80 , a situação dos homicídios na cidade de São Paulo muda: aumentam o número de vítimas e o risco (os coeficientes); aumenta o número de crimes cometidos por arma de fogo e, ao mesmo tempo, estes saem das residências e ganham as ruas.

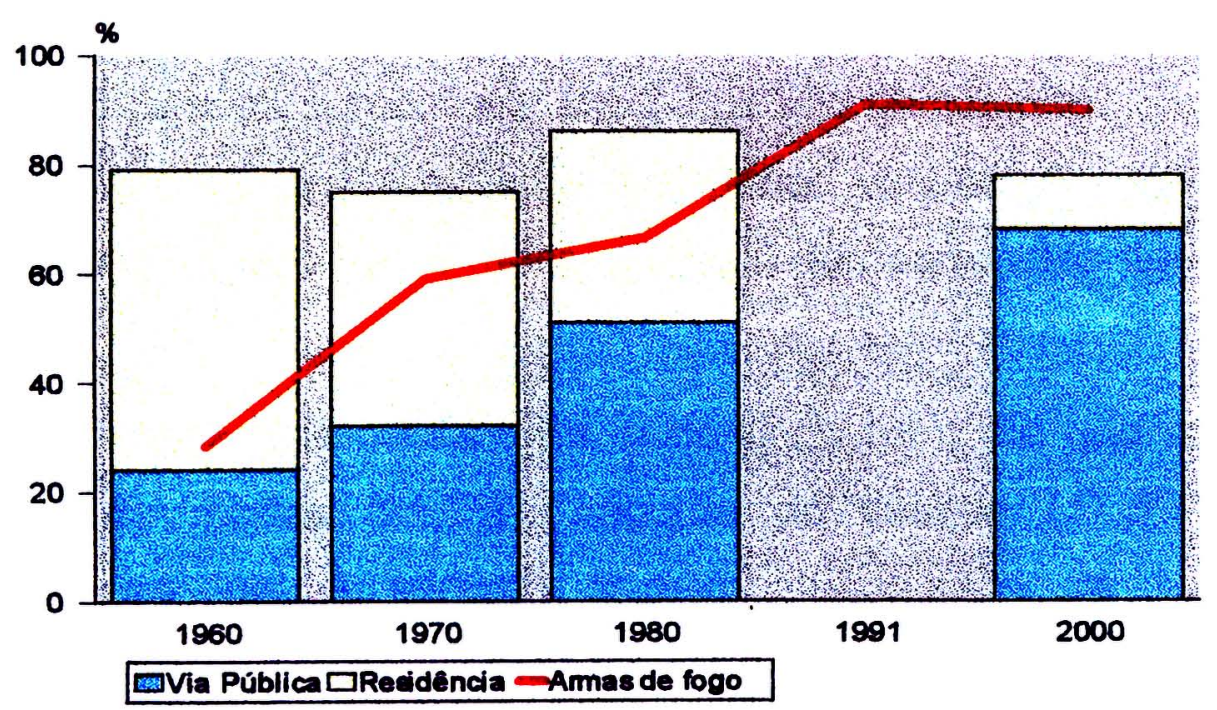

Fonte: Mello Jorge (1979, 1982), Gawryszewski (1995); Gawryszewski e Mello Jorge (2000)

Obs: Os percentuais relativos ao local de ocorréncia dos homicidios para o ano de 1991 náo encontram-se disponiveis

Figura 13- Homicídios segundo o tipo de local e utilizaçăo de arma de fogo (\%). Municipio de Såo Paulo, 60, 70, 80, 91 e 2000. 
No presente trabalho, năo foram observadas diferenças importantes entre o tipo de local e o uso de arma de fogo, embora se considere que o ideal teria sido poder contar com o total de casos ocorridos no ano.

\section{- Días da semana e horárío da ocorrência.}

As informações acerca do horário e dia da semana do fato constam em cem por cento dos Boletins de Ocorrència, sendo disponiveis somente nesse documento. Quando năo foi possível precisar o horário do fato, a autoridade policial fez constar no referido boletim: horário incerto, madrugada, manhá, noite, tarde.

As Tabelas 8 e 9 mostram a distribuição dos homicídios segundo o dia da semana e horário de ocorréncia. Contrariando o senso comum que vé a madrugada como potencialmente mais perigosa para a violencia, foram os horários noturnos (de 20:01 às 24:00 horas), que mostraram maior freqüéncia de mortes: $31,5 \%$ do total. As primeiras horas da madrugada (0:01 à 2:00 horas) também alcançam percentuais altos, que vão declinando com o passar das horas, associados provavelmente ao menor volume de pessoas que circulam nas ruas. Verificou-se o menor número de ocorréncias das 10:01 às $12: 00$ horas.

Em relação aos dias da semana, o domingo foi o dia que apresentou maior número de mortes $(21,7 \%)$, seguido do sábado $(17,5 \%)$, ambos correspondendo ao final de semana, o momento de lazer da maioria dos cidadãos. Um levantamento da Polícia Civil para os homicidios cuja autoria era desconhecida (DHPP, 1999) para os anos de 1997 e 1998 também mostrou que o domingo e o sábado foram os dias que tinham a maior proporção de mortes.

Também para os acidentes de trânsito os sábados, em primeiro lugar, e depois os domingos, concentram a maior freqüéncia de óbitos, especialmente 
nos horários noturnos (CET, 2001), fato que năo é novo, na medida que vem sendo mostrado por diversos autores.

Tabela 8:

Homicídios segundo horário da ocorrência ( $n^{\circ}$ e \%). Município de Såo Paulo, abril a junho de 2000.

\begin{tabular}{|c|c|c|}
\hline Horas & No. & $\%$ \\
\hline Oh00 às 1 h59 & 126 & 9,6 \\
\hline 2h00 às 3h59 & 89 & 6,8 \\
\hline $4 h 00$ às $5 h 59$ & 83 & 6,3 \\
\hline $6 h 00$ às 7 h59 & 78 & 5,9 \\
\hline $8 h 00$ às $9 h 59$ & 52 & 3,9 \\
\hline 10 h00 às $11 \mathrm{~h} 59$ & 39 & 3,0 \\
\hline $12 \mathrm{hOO}$ às $13 \mathrm{~h} 59$ & 63 & 4,7 \\
\hline $14 \mathrm{~h} 00$ às $15 \mathrm{~h} 59$ & 63 & 4,7 \\
\hline 16 hoods $17 \mathrm{~h} 59$ & 89 & 6,8 \\
\hline $18 h 00$ as $19 h 59$ & 140 & 10,7 \\
\hline $20 h 00$ às 21 h59 & 214 & 16,3 \\
\hline $22 \mathrm{hO}$ às $23 \mathrm{~h} 59$ & 198 & 15,1 \\
\hline Hora incerta & 30 & 2,3 \\
\hline Madrugada & 33 & 2,5 \\
\hline Noite & 8 & 0,6 \\
\hline Tarde & 4 & 0,3 \\
\hline Manhã & 4 & 0,3 \\
\hline Total & 1313 & 100,0 \\
\hline
\end{tabular}

Fonte: Boletins de Ocorréncia Policial (dados brutos)

Tabela 9:

Homicídios segundo os dias da semana de ocorrencia $\left(n^{\circ} e \%\right)$. Municipio de Såo Paulo, abril a junho de 2000.

\begin{tabular}{lcc}
\hline & Dia da semana & $\%$ \\
\hline Domingo & 284 & 21,6 \\
Segunda-feira & 171 & 13,0 \\
Terça-feira & 148 & 11,3 \\
Quarta-feira & 146 & 11,1 \\
Quinta-feira & 157 & 12,0 \\
Sexta-feira & 179 & 13,6 \\
Sábado & 228 & 17,4 \\
\hline Total & 1313 & 100,0 \\
\hline
\end{tabular}

Fonte: Boletins de Ocorréncia Policial (dados brutos) 
Em serviço de emergência na Espanha, Nunez e col. (2000), verificou que as vítimas de acidentes violentos tinham admissão predominantemente à noite e $35 \%$ delas, ocorreu no final de semana.

A análise da série histórica de mortalidade violenta, de 1960 a 1980 (Mello Jorge, 1979 e 1982), para todos os anos estudados, também é o final de semana que concentra a maior proporção de homicidios: ora o sábado ocupa o primeiro lugar, ora o domingo. Da mesma forma, os horários noturnos săo os mais freqüentes: especialmente entre 18 h00 e 23 h0o horas. Em segundo lugar está o horário da Oh00 às 5h59 horas da manhã.

Essas informaçóes tornam-se mais elucidativa, quando é realizada a análise conjunta dos dados de horários, com dias da semana de ocorréncia (Figura 14). A partir deste quadro, pode-se ver que a madrugada, que năo era o momento de maior número de ocorréncias durante os dias da semana, tornase verdade para o final de semana. O maior número de homicídios ocorridos no domingo é devido ao horário da madrugada, extensáo do sábado à noite, o momento da semana consagrado à diversão. Mesmo durante a semana, verifica-se que o horário noturno é, na realidade, o de maior número de ocorrências.

A análise conjunta dos dados a respeito do horário em que ocorreu o ato violento e o uso de álcool (entre as vítimas que tiveram exame toxicológico solicitado) mostra que há variação nas diferentes horas do dia, numa lógica esperada: os horários noturnos tendem a ter maior percentual de vítimas com exames positivos, enquanto que nos diurnos, essas proporções săo menores. Como exemplo pode ser citado o horário das $23 \mathrm{~h} 00$ horas, quando o percentual de uso de álcool chega a $60,9 \%$, enquanto às 14 h00 horas é de $31 \%$.

Carvalho (2002), ao estudar pacientes admitidos por causas externas em serviço de emergéncia, observou que o sábado apresentou a maior prevaléncia de alcoolemia, $35,1 \%$, seguido pela sexta-feira e quarta-feira. Ao comparar os plantōes diumos e noturnos, verificou que a prevaléncia foi maior entre os ültimos. 
A intenção, na verdade, é avaliar se houve assistência médica às vitimas. Em virtude de as armas de fogo serem o principal instrumento para a execução do homicídio, no início da pesquisa, acreditava-se que a maior parte destas vítimas, sequer recebia assistência médica. No entanto, isto necessitava ser conhecido (inclusive, continuamente e segundo as diferentes áreas geográficas), visto ser informação essencial para o planejamento e adequação dos serviços de saúde existentes ou proposição de novos serviços ou ampliação do atendimento pré-hospitalar.

A Tabela 10 mostra o local onde o óbito ocorreu a partir da informação da DO, em números absolutos e percentuais. Conclui-se que a maioria dos óbitos ocorreu no hospital $(63,5 \%)$, ficando em segundo lugar a via pública, com $26 \%$ das mortes. No entanto, é sabido que este é um dado pouco confiável, por não ser considerado importante no momento do preenchimento da DO, não sendo habitualmente utilizado nas análises epidemiológicas.

Tabela 10:

Distribuição dos homicídios segundo o local de ocorrência do óbito ( $n^{\circ}$ e \%). Município de São Paulo, 2000.

\begin{tabular}{l|c|c}
\hline \multicolumn{1}{c|}{ Local de ocorrência } & No. & $\%$ \\
\hline Hospital & 3796 & 63,5 \\
Via Pública & 1554 & 26,0 \\
Domicílio & 262 & 4,4 \\
Outro & 352 & 5,9 \\
Ignorado & 14 & 0,2 \\
\hline Total & 5978 & 100,0 \\
\hline
\end{tabular}

Fonte: Declaração de Óbito (PRO-AIM)

No início da pesquisa, pensou-se que a informação mais fidedigna a respeito desta questão poderia ser obtida nos laudos de necropsia do IML, o 


\begin{tabular}{|l|l|l|l|l|l|l|l|}
\hline $\begin{array}{c}\text { Dia da semanal } \\
\text { Hora do dia }\end{array}$ & Segunda & Terça & Quarta & Quinta & Sexta & Sábado & Domingo \\
\hline Oh01 às 2h00 & & & & & & & \\
\hline $2 \mathrm{~h} 01$ às $4 \mathrm{~h} 00$ & & & & & & & \\
\hline $4 \mathrm{~h} 01$ às $6 \mathrm{~h} 00$ & & & & & & & \\
\hline $6 \mathrm{~h} 01$ às $8 \mathrm{~h} 00$ & & & & & & & \\
\hline $8 \mathrm{~h} 01$ às $10 \mathrm{~h} 00$ & & & & & & & \\
\hline $10 \mathrm{~h} 01$ às $12 \mathrm{~h} 00$ & & & & & & & \\
\hline $12 \mathrm{~h} 01$ às $14 \mathrm{~h} 00$ & & & & & & & \\
\hline $14 \mathrm{~h} 01$ às $16 \mathrm{~h} 00$ & & & & & & & \\
\hline $16 \mathrm{~h} 01$ às $18 \mathrm{~h} 00$ & & & & & & & \\
\hline $18 \mathrm{~h} 01$ às $20 \mathrm{~h} 00$ & & & & & & & \\
\hline $20 \mathrm{~h} 01$ às $22 \mathrm{~h} 00$ & & & & & & & \\
\hline 22h01 às $24 \mathrm{hn00}$ & & & & & & & \\
\hline
\end{tabular}

0-9 hom. $\square$ 10-19 hom. 20-29 hom. $\square$ 30-39 hom.

Figura 14: Homicídios segundo dias e horário da semana de ocorrência. Município de São Paulo, abril a junho de $\mathbf{2 0 0 0 .}$ 
que não se confirmou, visto que no laudo consta somente o nome do hospital de onde a vítima foi encaminhada, não sendo possivel saber se houve alguma assistência médica. De qualquer modo, é uma informação importante de ser quantificada, na medida em que é possível conhecer quais são os hospitais com maior demanda para estas vitimas $e$, consequentemente, planejar ações. Além disso, é possivel conhecer as mortes por seqüelas tardias de tentativas de homicídio, que no período de estudo, foram registrados somente dois casos nesta situação, um deles vítima de ferimento por arma de fogo há cerca de um ano e o outro há três meses.

No entanto, a despeito de não ter um campo padronizado para este dado no Boletim de Ocorrência, tal informação constou em $96,7 \%$ dos documentos pesquisados. Este percentual alto demonstra que é uma informação valorizada nos $\mathrm{BO}$, visto que o número de Delegacias de Polícia no Município é expressivo (101). Além disso, trabalham em cada uma delas diferentes equipes de investigação nos vários plantões. Mesmo assim, a quase totalidade dos registros conta com esta informação, com um certo detalhamento (apresentado na Tabela 11).

Tabela 11:

Homicídios segundo possibilidade de socorro médico $\left(n^{\circ} \mathrm{e} \%\right)$. Município de São Paulo, abril a junho de 2000.

\begin{tabular}{lcc}
\hline \multicolumn{1}{c}{ Socorro Médico } & No. & $\%$ \\
\hline Faleceu no Pronto-Socorro & 631 & 48,0 \\
Encontrado morto/ faleceu no local do crime & 514 & 39,1 \\
Faleceu a caminho do Pronto-Socorro/ entrou em óbito no & 92 & 7,1 \\
Pronto-Socorro & 33 & 2,5 \\
Internação & 43 & 3,3 \\
Ignorado & 1313 & 100,0 \\
\hline Total & &
\end{tabular}

Fonte: Boletins de Ocorrência (dados brutos)

$\mathrm{Na}$ classificação de categorias, procurou-se obedecer ao que vinha escrito no documento, inclusive mantendo-se frases que sugerem 
duplicidade, como por exemplo "encontrado morto" e "faleceu no local do crime". Os óbitos na primeira categoria parecem corresponder aos corpos que foram encontrados pela polícia ou por civis, enquanto o segundo está relacionado àquelas ocorrências mais imediatas, onde não houve tempo para levar a vítima ao hospital. Como isso não é uma instrução, há limitações em sua análise e para os objetivos pelos quais esse dado é analisado neste trabalho, que é saber quantas vítimas conseguiram chegar a algum hospital, essas duas "categorias" foram somadas, o que correspondeu a $39,1 \%$ do total de óbitos. Além disso, também não é possivel saber se, quando foi anotado que a "vítima morreu no PS", houve real possibilidade de realização de um primeiro atendimento ou se esta foi levada para a emergência, pela polícia, parentes ou amigos já em óbito. Do mesmo modo para aquelas vítimas que "morreram a caminho do PS", não é possível saber se houve participação do resgate e, portanto, algum tipo de atendimento.

Apesar das limitações aqui apontadas, esta variável é essencial para uma melhor organização do atendimento a estas vítimas e a melhor informação foi obtida no BO. Por isso, considera-se que, para o estabelecimento de uma proposta para a vigilância de homicídios, esse dado deve continuar sendo coletado no $\mathrm{BO}$, sendo que a princípio deve ser utilizada a informação registrada disponivel, que posteriormente deve ser objeto de aperfeiçoamento.

Apesar da discutivel qualidade dessa informação, observa-se que a possibilidade de atendimento existiu para um pouco mais da metade dessas vítimas, que somam $57,6 \%$ do total, que são excluídas aquelas que foram encontradas mortas, faleceram no local ou cuja informação era ignorada. Isto é coerente com a informação obtida via DO, quando mostra (Tabela 11) que $63,5 \%$ dessas vítimas foram levadas ao hospital, mas é maior do que se esperava.

Denunciando a gravidade das lesōes determinadas pelas armas de fogo, verifica-se que o número de internações em relação ao total de ocorrências é pequeno, apenas 33 casos $(2,5 \%)$, sendo que 15 deles permaneceram internados por menos de 24 horas. Disto decorre que o 
planejamento para um eficiente atendimento pré-hospitalar é medida fundamental para diminuir a letalidade desse agravo.

Nos anos de 1960, 1965 e 1970 (Mello Jorge, 1979 e 1982), a maioria dos óbitos também ocorreu no próprio local do evento, mas com percentuais um pouco mais elevados que os atuais, o que pode refletir as maiores dificuldades no transporte das vítimas. Por outro lado, os percentuais de vitimas que foram internadas, são mais altos que os encontrados neste trabalho. Como exemplo, óbitos com tempo de internação maior que 24 horas chegaram a 11,5\% em 1975, quando em 2000 representam somente $1,3 \%$. Levando em consideração que, atualmente, os recursos que as emergências dispõem são mais avançados que há 25 anos, é possivel inferir que, o maior acesso às armas de fogo e o aumento da sua potência, possibilitou um aumento da letalidade desses crimes.

\section{- A questão da motivação}

O que motiva estes crimes é a grande pergunta que os cidadãos já fizeram a si mesmos ou discutiram com outros, e que, certamente, gostariam de ver respondida. No entanto, na pesquisa a esta fonte, no momento atual, isto ainda não foi possível.

No $\mathrm{BO}$, è reservada uma parte, que corresponde ao chamado "histórico do caso", onde o escrivão pode descrever dados sobre as circunstâncias do crime, depoimento de testemunhas etc. Somente em 327 BO do período estudado $(24,9 \%)$ a motivação desses crimes foi identificada nestes "históricos". $\mathrm{Na}$ verdade, esse baixo percentual não provocou surpresa, visto que dados para o ano de 1995 (Lima, 2000), mostraram percentuais ainda menores, pois dos 4.277 crimes de homicídios ocorridos no Municipio de São Paulo naquele ano, apenas $392(9,2 \%)$ referiam-se a crimes de autoria conhecida no momento de registro da ocorrência. Neste último grupo, certamente, encontra-se a maior parte dos crimes em que é 
possivel saber a motivação, principalmente quando são crimes não premeditados, ocorrendo no ápice de um conflito familiar ou entre conhecidos. Por certo, não é provável saber a motivação de todos os crimes de autoria conhecida (registrou-se, inclusive, um caso de prisão em flagrante cujo autor não revelou a razão do crime). Da mesma forma, algumas vezes é possível saber o motivo, mas se desconhece o autor.

As informações mostradas na Tabela 12 referem-se aos crimes cuja motivação foi conhecida nos registros de BO, ou seja na ocasião do evento. Os conflitos interpessoais foram responsáveis por $29,6 \%$ desses óbitos. Nesta categoria, foram incluídas todas as sortes de confrontos, conflitos em casa e nos bares, as vinganças, os "jurados de morte" (embora esse termo possa estar relacionado com os conflitos do tráfico de drogas) e as brigas de trânsito (em número de seis). Deste fato, pode-se inferir a intensidade da perda do valor da vida. As tensões se transformando em violência.

Tabela 12:

Distribuição dos homicídios Segundo a motivação do crime $\left(n^{\circ}\right.$ e \%). Município de Săo Paulo, abril, maio e junho de 2000.

\begin{tabular}{lcc}
\hline \multicolumn{1}{c}{ Motivação } & No. & $\%$ \\
\hline Conflito interpessoal & 97 & 29,6 \\
Latrocinio & 76 & 23,2 \\
Execução & 54 & 16,5 \\
Passional & 25 & 7,6 \\
Intervençōes legais & 17 & 5,2 \\
Relacionado com drogas & 15 & 4,6 \\
Bala Perdida & 11 & 3,4 \\
Dívida financeira & 9 & 2,8 \\
Outros & 23 & 6,1 \\
\hline Total & 327 & 100,0 \\
\hline
\end{tabular}

Fonte: Boletins de Ocorrência Policial (dados brutos)

Em segundo lugar, seguem-se os latrocínios, com 23,2\%, que também são crimes identificados com maior facilidade. Entre estes, a maior parte 
aconteceu em razão de tentativa de fuga da vítima ou porque esta tentou reação armada, porém alguns casos resultaram em morte da vitima por esta não possuir dinheiro. Na categoria "outros" encontram-se nove casos em que ocorreu o fato contrário: ao reagir ao assalto, algumas pessoas acabam por matar o assaltante, denunciando o quanto a violência perpassa toda a sociedade e apontando para que estudos devem ser realizados para identificar a magnitude da posse de armas por parte do cidadão comum.

Os casos classificados como execuções $(16,5 \%)$ são aqueles crimes nos quais as vítimas são mortas sem qualquer discussão prévia, sem chance de defesa, geralmente por indivíduos encapuzados ou que chegam em motocicletas. Por vezes os agressores nem conhecem as vitimas: vão até as residências, chamam o nome da vítima e quando estas se apresentam, são mortas. Para a área de segurança, esses crimes estão geralmente ligados ao crime organizado.

Os crimes passionais $(7,6 \%)$ não dizem respeito somente as mortes decorrentes de ciúmes mas também às mortes de familiares que proibiram os namoros. Na categoria "outros" se encontram três crimes cujas vítimas apresentavam indícios de abuso sexual, quatro chacinas/massacres e três homicidios que podem ser classificados como acidente de trabalho típico (um policial militar e dois guardas da segurança privada).

Lima (2000), ao comparar a motivação de crimes de autoria conhecida e desconhecida, ocorridos no Município de São Paulo no ano de 1995 verificou diferenças marcantes entre eles. Enquanto entre os primeiros, os conflitos interpessoais precipitaram $46,2 \%$ dessas mortes, já para o segundo grupo tais conflitos levaram somente a $25,2 \%$. O crime organizado respondeu por apenas $1 \%$ para o primeiro grupo, tendo subido para $10,3 \%$, no segundo grupo.

Tanto a área de segurança pública quanto outros setores da sociedade consideram que a maior parte dos crimes ocorridos esteja relacionada ao uso e comércio de drogas; no entanto, isso tem sido difícil de demonstrar no Município de São Paulo, devido ao grande número de mortes sem autoria determinada, em parte porque esse tipo de crime é protegido 
mais fortemente pela "lei do silêncio" do que os crimes passionais ou aqueles relacionados aos conflitos/desavenças.

Embora os resultados numéricos não sejam animadores, é aqui que o número se transforma em espanto e indignação: é na parte do chamado "histórico" do BO que se encontram registradas as dores da sociedade.

- Pessoas morrem simplesmente porque não tinham dinheiro para dar ao assaltante: homem, 61 anos, escondeu o dinheiro no bolso mas foi descoberto.

- Alguém foi morto porque enfiou o dedo na cerveja do outro, talvez não soubesse que aquele individuo já tinha cometido um homicídio.

- Sexo masculino era amigo de "infratores", foi morto porque "caguetava", tinha somente 14 anos.

- Classificado como briga de trânsito: homem discutiu com motorista que tinha colidido em seu carro e foi morto. Este agressor tinha seqüestrado alguém que, naquele momento, se encontrava preso no porta malas.

- Vítima e agressor eram irmãos, o primeiro costumava ligar o som muito alto, impossibilitando o agressor de ver televisão.

É fundamental juntar esforços, dos vários setores, para buscar a melhoria da investigação dos motivos que levam ao crime, visto ser informação crítica para o estabelecimento de estratégias de prevenção. Se a motivação em determinado local estiver relacionada com crimes passionais, a estratégia do ponto de vista da área da saúde poderá se dar, por exemplo, por meio da implantação, nos serviços de saúde, de equipes multiprofissionais com ênfase no trabalho de resolução de conflitos intrafamiliares. Se, em outros locais, a motivação principal desses crimes estiver ligada ao tráfico de drogas, pode-se pensar em se estabelecerem serviços voltados para o atendimento aos dependentes de álcool e drogas; se há jovens envolvidos em gangues, deve-se trabalhar com as escolas etc. Um dos projetos que vêm sendo desenvolvidos pela Secretaria de Educação 
do Estado de São Paulo é o Parceiros do Futuro, que segue uma tendência internacional de trabalhar envolvendo a comunidade, com o objetivo de minimizar o potencial de desenvolvimento da violência. Recentemente, a Secretaria da Saúde do Estado de São Paulo também se agregou a esse Projeto.

\subsection{A distribuição espacial das mortes por homicidios}

\section{- Os homicidios segundo o local de residêncía}

Em relação à distribuição espacial das mortes por homicídios, os óbitos ocorridos no Município de São Paulo foram analisados segundo os distritos de residência da vítima, a partir dos dados globais do ano de 2.000 . Esta análise é fundamental para focalizar aqueles locais nos quais devem ser concentrados esforços e recursos para a prevenção do problema.

As taxas encontradas para a população residente mostram, mais uma vez, a grande desigualdade existente na ocupação do espaço urbano, expressada na morte violenta. Se o coeficiente global do Municipio de São Paulo é alto, isso não é verdade para qualquer local. As diferenças são marcantes (tanto nos números absolutos, quanto nos coeficientes) entre alguns locais, citando-se, como exemplo, o distrito do Jardim Paulista, cujo coeficiente foi de 3,6/100.000 habitantes, enquanto que Parelheiros apresentou coeficiente de 106,3 (28 vezes maior).

Encontram-se assinalados em vermelho, na Tabela 13, os vinte e cinco distritos que apresentaram valores maiores que a média do Município. Para melhor observar esta distribuição espacial, os coeficientes de mortalidade por homicídios foram dispostos em mapa (Figura 15), sendo as taxas classificadas em quatro faixas: 
- até 24,9/100.000: risco baixo (23 distritos, $24 \%$ encontram-se nesta faixa);

- de 25 a 49,9/1000.000: risco médio (36 distritos, 37,5\% foram contados nesta faixa);

- de 50 a 74,9/100.000: risco alto (aqui encontram-se 23 distritos, correspondendo a $24 \%$ );

- 75/100.000 e mais: risco altíssimo (14 distritos, $14,5 \%$ );

Tabela 13:

Distribuiçăo dos homicidios(no. , \% e coeficiente/100.000) segundo local de residéncia. Município de Săo Paulo, 2000.

\begin{tabular}{|c|c|c|c|}
\hline \multirow[t]{2}{*}{ Distrito } & \multicolumn{3}{|c|}{ Residéncia } \\
\hline & No. & $\%$ & \\
\hline Água Rasa & 26 & 0,4 & 30,3 \\
\hline Alto de Pinheiros & 8 & 0,1 & 18,0 \\
\hline Anhanguera & 9 & 0,2 & 23,3 \\
\hline Aricanduva & 43 & 0,7 & 45,4 \\
\hline Artur Alvim & 50 & 0,8 & 45,1 \\
\hline Barra Funda & 4 & 0,1 & 30,9 \\
\hline Bela Vista & 18 & 0,3 & 28,5 \\
\hline Belém & 15 & 0,3 & 39,2 \\
\hline Bom Retiro & 11 & 0,2 & 41,4 \\
\hline Brás & 18 & 0,3 & 73,5 \\
\hline Brasilandia & 216 & 3,6 & 87,5 \\
\hline Butanti & 17 & 0,3 & 32,4 \\
\hline Cachooirinha & 130 & 2,2 & 88,1 \\
\hline Cambuci & 9 & 0,2 & 31,4 \\
\hline Campo Belo & 13 & 0,2 & 19,6 \\
\hline Campo Grando & 49 & 0,8 & 53,7 \\
\hline Campo Limpo & 100 & 1,7 & 52,4 \\
\hline Cangaiba & 45 & 0,8 & 33,1 \\
\hline Capło Redondo & 154 & 2,6 & 63,5 \\
\hline Carrăo & 26 & 0,4 & 33,5 \\
\hline Casa Verde & 22 & 0,4 & 26,3 \\
\hline Cidade Ademar & 166 & 2,8 & 68,2 \\
\hline Cidade Dutra & 149 & 2,5 & 78,4 \\
\hline Cidade Lider & 71 & 1,2 & 61,1 \\
\hline Cidado Tiradentes & 195 & 3,3 & 102,3 \\
\hline Consotaçáo & 8 & 0,1 & 14,7 \\
\hline Cursino & 49 & 0,8 & 48,1 \\
\hline Ermelino Matarazzo & 73 & 1,2 & 68,4 \\
\hline Freguesia do Ó & 47 & 0,8 & 32,5 \\
\hline Grajaú & 286 & 4,8 & 86,2 \\
\hline Guainazes & 101 & 1,7 & 102,3 \\
\hline Iguatemi & $\pi 7$ & 1,3 & 75,7 \\
\hline Ipiranga & 36 & 0,6 & 36,6 \\
\hline Itaim Bibi & 10 & 0,2 & 12,3 \\
\hline Itaim Paulista & 125 & 2,1 & 58,8 \\
\hline Itaquera & 140 & 2,3 & 69,6 \\
\hline Jabaquara & 118 & 2,0 & 55,1 \\
\hline Jaçanå & 47 & 0,8 & 51,3 \\
\hline Jaguará & 5 & 0,1 & 19,4 \\
\hline
\end{tabular}


Tabela 13 (continuação)

Distribuição dos homicídios(no. , \% e coeficiente/100.000) segundo local de residência. Município de São Paulo, 2000.

\begin{tabular}{|c|c|c|c|}
\hline \multirow[t]{2}{*}{ Distrito } & \multicolumn{3}{|c|}{ Residência } \\
\hline & No. & $\%$ & \\
\hline Jaguaré & 18 & 0,3 & 42,4 \\
\hline Jaraguá & 79 & 1,3 & 54,3 \\
\hline Jardim Ângela & 223 & 3,7 & 91,4 \\
\hline Jardim Helena & 93 & 1,6 & 67,1 \\
\hline Jardim Paulista & 3 & 0,1 & 3,6 \\
\hline Jardim S. Luis & 202 & 3,4 & 85,2 \\
\hline José Bonifácio & 52 & 0,9 & 48,6 \\
\hline Lajeado & 104 & 1,7 & 65,9 \\
\hline Lapa & 5 & 0,1 & 8,3 \\
\hline Liberdade & 17 & 0,3 & 27,5 \\
\hline Limão & 42 & 0,7 & 51,2 \\
\hline Mandaqui & 24 & 0,4 & 23,3 \\
\hline Marsilac & 1 & 0,0 & 11,2 \\
\hline Moema & 5 & 0,1 & 7,2 \\
\hline Mooca & 22 & 0,4 & 34,8 \\
\hline Morumbi & 19 & 0,3 & 56,1 \\
\hline Parelheiros & 109 & 1,8 & 106,3 \\
\hline Pari & 5 & 0,1 & 34,4 \\
\hline Parque do Carmo & 39 & 0,7 & 61,0 \\
\hline Pedreira & 60 & 1,0 & 47,1 \\
\hline Penha & 29 & 0,5 & 23,5 \\
\hline Perdizes & 6 & 0,1 & 5,9 \\
\hline Perus & 23 & 0,4 & 32,5 \\
\hline Pinheiros & 6 & 0.1 & 9,6 \\
\hline Pirituba & 67 & 1,1 & 41,4 \\
\hline Ponte Rasa & 31 & 0,5 & 31,8 \\
\hline Raposo Tavares & 41 & 0,7 & 45,3 \\
\hline República & 27 & 0,5 & 56,9 \\
\hline Rio Pequeno & 20 & 0,3 & 17,9 \\
\hline Sacomä & 116 & 1,9 & 51,0 \\
\hline Santa Cecilia & 22 & 0,4 & 30,9 \\
\hline Santana & 28 & 0,5 & 22,4 \\
\hline Santo Amaro & 16 & 0,3 & 26,8 \\
\hline Săo Domingos & 15 & 0,3 & 18,1 \\
\hline São Lucas & 56 & 0,9 & 40,3 \\
\hline São Mateus & 142 & 2,4 & 91,7 \\
\hline São Miguel & 55 & 0,9 & 56,5 \\
\hline Sāo Rafael & 102 & 1,7 & 81,5 \\
\hline Sapopemba & 206 & 3,4 & 73,0 \\
\hline Saúde & 16 & 0,3 & 13,6 \\
\hline Sé & 20 & 0,3 & 99,5 \\
\hline Socorro & 13 & 0,2 & 33,3 \\
\hline Tatuapé & 16 & 0,3 & 20,2 \\
\hline Tremembé & 73 & 1,2 & 44,6 \\
\hline Tucuruvi & 22 & 0,4 & 22,2 \\
\hline Vila Andrade & 22 & 0,4 & 29,2 \\
\hline Vila Curuçá & 117 & 2,0 & 80,0 \\
\hline Vila Formosa & 27 & 0,5 & 28,8 \\
\hline Vila Guilherme & 13 & 0,2 & 26,0 \\
\hline Vila Jacuí & 74 & 1,2 & 52,2 \\
\hline Vila Leopoldina & 3 & 0,1 & 11,2 \\
\hline Vila Maria & 45 & 0,8 & 40,0 \\
\hline Vila Mariana & 20 & 0,3 & 16,2 \\
\hline Vila Matilde & 30 & 0,5 & 29,3 \\
\hline Vila Medeiros & 74 & 12 & 52,7 \\
\hline Vila Prudente & 29 & 0,5 & 28,4 \\
\hline Vila Sônia & 21 & 0,4 & 24,1 \\
\hline Ignorado & 527 & 8,8 & \\
\hline Total & 5978 & 100,0 & 57,4 \\
\hline
\end{tabular}


Entre os distritos que estão classificados como de risco altíssimo, a regiāo da zona leste lidera o ranking, concentrando a maior parte dos distritos (Cidade Tiradentes, Guaianazes, Cidade Dutra, Iguatemi, São Rafael, São Mateus e Vila Curuçá). Na zona sul da cidade encontram-se cinco (Parelheiros, Grajaú, Jardim Ângela e Jardim S. Luis), dois localizamse na zona Norte (Brasilândia e Cachoeirinha) e um deles (Sé), na região central.

Tornou-se a zona leste mais violenta que a zona sul da cidade? Não se pode afirmar isto, pois na verdade, a maior parte destes distritos vem, já há algum tempo, exibindo coeficientes altos e, revezando-se a cada ano no primeiro lugar.

A comparação com dados de anos anteriores, mostra que esta situação vem se agravando, pois verifica-se um amento nos coeficientes calculados para cada distrito. Entre 1996 e 2000, a estimativa do risco de mortes por homicídios aumentou em 68 dos 96 distritos da Capital: a violência vem se espalhando pela cidade.

Não é possivel comparar essas taxas com as observadas no início da década. $\mathrm{A}$ análise fica prejudicada devido às diferenças na divisão territorial ocorrida em 1996, quando o Município passou de 59 para 96 distritos. Apesar desse limite, pode-se observar que Cachoeirinha e Brasilândia ocuparam o primeiro e o quinto lugar respectivamente, entre os distritos com maiores taxas de mortalidade por homicídios, em estudo realizado para o ano de 1991 (Gawryszewski, 1995). Parelheiros, que ocupa a primeira posição em 2.000, ocupava a segunda em 1991. Santo Amaro, Guaianazes, Itaim Paulista e Itaquera também já exibiam altos indices, no início da década de 90 . Tomando a região central como comparação, do mesmo modo, a Sé e o Brás figuravam entre os distritos com maior risco de homicídios.

Aqueles que apresentam os menores coeficientes, no ano de 2000, são, em ordem decrescente: Jardim Paulista, Perdizes, Moema, Lapa, Pinheiros, Alto de Pinheiros, Itaim Bibi, Campo Belo e Consolação. Esses 
distritos que apresentam menores taxas de mortalidade violenta correspondem àqueles onde mora a população com condições de vida mais favoráveis. Além desses índices se apresentarem mais baixos em relação às outras regiões da cidade, quando são comparados os anos de $2000 \mathrm{com}$ 1996, verificou-se pequena queda nas taxas destas regiões (para 10 distritos).

Os distritos que apresentam os maiores coeficientes são os que pertencem às zonas centrais e periféricas da cidade. Analisando a década de 80, a Secretaria Municipal do Planejamento do Município de S. Paulo (SEMPLA, 1991), refere que esta década concentrou, no centro da cidade, uma população de baixa renda maior que nas regiões periféricas, pois muitos habitantes tiveram que deixar as casas da periferia e dirigir-se para os cortiços das zonas mais centrais. Por outro lado, parte das camadas remediadas da população teve que abandonar as moradias situadas em zonas mais próximas ao centro e rumar para a periferia. Essa década, que se abre com a recessão de 1981-83, marca uma tendência de empobrecimento de uma parcela considerável da população de uma das regiōes mais ricas do país, que é o Municipio de São Paulo. Já as regiōes do Municipio com predominância de estratos de alta renda atravessaram a década de $80 \mathrm{com}$ menores variações quantitativas em suas populações.

A avaliação do que ocorreu nos anos 90 , em relação à ocupação do espaço urbano, é dificultada porque somente foram divulgados alguns dos dados preliminares do Censo 2.000, realizado pelo IBGE. Ainda assim, análises realizadas e publicadas no Jornal Folha de S. Paulo mostram que prossegue o esvaziamento do centro e a migração das camadas de baixa renda rumo à periferia. Em relação à região central, contribui para isto, a contínua mudança do uso de imóveis dessa região (residencial para comercial) e a degradação do espaço urbano.

Além disso, esse esvaziamento ultrapassa os limites oficiais da região central, seguindo rumo à periferia urbanizada, pois na medida em que algumas áreas vão melhorando suas condições de urbanização e contando 
com maior número de serviços, o custo dos imóveis aumenta, tornando inviável para uma parcela da população continuar vivendo nesses locais. Segundo ressalta Santos (1998), os incluidos de uma época, podem ser os excluídos de outra.

A migração resultante deu-se em direção às zonas leste e à zona sul, que foram as áreas que mais cresceram.

É possivel, assim, concluir que, embora o temor da violência perpasse por toda a sociedade, pode-se observar, pelos dados aqui levantados que, em relação à mortalidade, as vitimas de fato estão concentradas em alguns limites geográficos.

Certamente a preocupação das camadas médias não é infundada. Akerman \& Bousquat (1999) apontam que, diferentemente do que ocorre com as taxas de homicídios, existe uma relação inversa entre os furtos e os roubos $e$ as condições sócio-econômicas das áreas abrangidas pelas seccionais de polícia. Isto é, as seccionais com os melhores índices socioeconômicos apresentam maiores proporções de furtos e roubos e maiores riscos para lesōes corporais. As três seccionais com os piores indices socioeconômicas são aquelas que apresentam os três maiores riscos para homicídios e os três menores para furto.

É necessário apontar que um dos limites desta informação diz respeito ao número expressivo de endereços classificados como ignorados, que perfazem $8,8 \%$ do total do ano de 2000, representando 524 óbitos. Para 23 deles $(4,4 \%)$, não foi possivel localizar a residência nas publicações de guia de ruas da cidade. No entanto, a maior parte $(504,95,6 \%)$ corresponde às vitimas que não constavam endereço na Declaração de Óbito, podendo tratar-se de desconhecido e/ou morador de rua ou não preenchimento do campo pelo IML. Uma outra possibilidade é que a vítima tenha sido identificada, porque possuia documento de identidade na ocasiāo da morte, mas nenhum parente ou amigo foi reclamar o corpo. Isso pode ser devido

\footnotetext{
${ }^{7}$ Jornal Folha de São Paulo, Caderno Cotidiano, 10 de maio de 2001.
} 
aos custos do funeral, pois quando não há conhecidos da vitima, é o próprio IML quem realiza esse sepultamento.

No entanto, o maior obstáculo apontado para esta informação é que, não se pode inferir quais lugares correspondem às zonas mais ou menos violentas do Município, em razão de não se referir ao local de ocorrência do evento, mas, sim, ao local de residência da vítima. Trata-se somente dos distritos onde seus residentes estão submetidos a maiores (ou menores) situaçōes de acidentes e violências.

- Os homicidios segundo local de ocorrência: retratando a guerra urbana.

Em relação à distribuição espacial dos óbitos por homicidios, a pesquisa nos Boletins de Ocorrência permitiu que essas mortes também fossem conhecidas segundo o local onde ocorreu o óbito. Essa informação é vital para a identificação das áreas onde devem ser concentrados os esforços de intervenções.

Na impossibilidade de calcular "coeficientes de ocorrência", uma vez que o denominador é desconhecido, pois deveria ser composto pela população residente somada àquela que freqüenta a região, foram construídos então índices por local de ocorrência (Tabela 14 e Figura 16), cujo numerador foi o número de óbitos por homicidios ocorridos no distrito $e$ o denominador, a população residente. A razão para isso é a importância de verificar se existe coincidência entre as taxas de homicídios segundo o local de residência e ocorrência. Por certo, este dado deve ser analisado com reservas, principalmente em relação à região central que possui populações pequenas e apresenta uma grande circulação de pessoas, o que faz aumentar o número de pessoas expostas. 
Tabela 14:

Distribuição dos homicídios segundo local de residéncia e local de ocorrência (por 100.000). Município de São Paulo, abril a junho de 2000.

\begin{tabular}{|c|c|c|}
\hline Distrito & Residência & Ocorrência \\
\hline Água Rasa & 30,3 & 9,3 \\
\hline Alto de Pinheiros & 18,0 & 9,0 \\
\hline Anhanguera & 23,3 & 31,2 \\
\hline Aricanduva & 45,4 & 54,9 \\
\hline Artur Alvim & 45,1 & 28,9 \\
\hline Barra Funda & 30,9 & 154,6 \\
\hline Bela Vista & 28,5 & 12,7 \\
\hline Belém & 39,2 & 83,6 \\
\hline Bom Retiro & 41,4 & 105,4 \\
\hline Brás & 73,5 & 65,3 \\
\hline Brasilândia & 87,5 & 55,1 \\
\hline Butantã & 32,4 & 38,1 \\
\hline Cachoeirinha & 88,1 & 70,5 \\
\hline Cambuci & 31,4 & 41,9 \\
\hline Campo Belo & 19,6 & 6,0 \\
\hline Campo Grande & 53,7 & 70,2 \\
\hline Campo Limpo & 52,4 & 58,7 \\
\hline Cangaíba & 33,1 & 17,6 \\
\hline Capāo Redondo & 63,5 & 79,2 \\
\hline Carrão & 33,5 & 30,9 \\
\hline Casa Verde & 26,3 & 47,8 \\
\hline Cidade Ademar & 68,2 & 77,3 \\
\hline Cidade Dutra & 78,4 & 94,7 \\
\hline Cidade Líder & 61,1 & 51,6 \\
\hline Cidade Tiradentes & 102,3 & 96,6 \\
\hline Consolaçāo & 14,7 & 22,1 \\
\hline Cursino & 48,1 & 31,4 \\
\hline Ermelino Matarazzo & 68,4 & 67,5 \\
\hline Freguesia do $\delta$ & 32,5 & 24,9 \\
\hline Grajaú & 86,2 & 79,5 \\
\hline Guainazes & 102,3 & 65,2 \\
\hline Iguatemi & 75,7 & 47,2 \\
\hline Ipiranga & 36,6 & 44,8 \\
\hline Itaim Bibi & 12,3 & - \\
\hline Itaim Paulista & 58,8 & 56,4 \\
\hline Itaquera & 69,6 & 55,7 \\
\hline Jabaquara & 55,1 & 35,5 \\
\hline Jaçanã & 51,3 & 61,1 \\
\hline Jaguará & 19,4 & 62,2 \\
\hline Jaguaré & 42,4 & 75,5 \\
\hline Jaraguá & 54,3 & 38,4 \\
\hline Jardim Ångela & 91,4 & 98,4 \\
\hline Jardim Helena & 67,1 & 51,9 \\
\hline Jardim Paulista & 3,6 & 9,7 \\
\hline Jardim S. Luis & 85,2 & 108,0 \\
\hline José Bonifácio & 48,6 & 33,6 \\
\hline Lajeado & 65,9 & 76,0 \\
\hline Lapa & 8,3 & 26,6 \\
\hline Liberdade & 27,5 & 6,5 \\
\hline Limão & 51,2 & 34,1 \\
\hline Mandaqui & 23,3 & 15,5 \\
\hline Marsilac & 11,2 & - \\
\hline Moema & 7,2 & 5,7 \\
\hline Mooca & 34,8 & 6,3 \\
\hline Morumbi & 56,1 & 23,6 \\
\hline Parelheiros & 106,3 & 81,9 \\
\hline Pari & 34,4 & 27,5 \\
\hline Parque do Carmo & 61,0 & 31,3 \\
\hline Pedreira & 47,1 & 78,4 \\
\hline Penha & 23,5 & 29,2 \\
\hline Perdizes & 5,9 & 11,7 \\
\hline Perus & 32,5 & 45,3 \\
\hline
\end{tabular}


Tabela 14 (continuação):

Distribuição dos homicídios segundo local de residência e local de ocorrência (por 100.000). Município de São Paulo, abril a junho de 2000.

\begin{tabular}{|c|c|c|}
\hline Distrito & Residência & Ocorrência \\
\hline Pinheiros & 9,6 & 25,6 \\
\hline Pirituba & 41,4 & 54,4 \\
\hline Ponte Rasa & 31,8 & 16,4 \\
\hline Raposo Tavares & 45,3 & 53,0 \\
\hline República & 56,9 & 101,1 \\
\hline Rio Pequeno & 17,9 & 28,6 \\
\hline Sacomã & 51,0 & 38,7 \\
\hline Santa Cecilia & 30,9 & 28,1 \\
\hline Santana & 22,4 & 9,6 \\
\hline Santo Amaro & 26,8 & 60,2 \\
\hline São Domingos & 18,1 & 24,1 \\
\hline São Lucas & 40,3 & 40,3 \\
\hline São Mateus & 91,7 & 59,4 \\
\hline São Miguel & 56,5 & 69,9 \\
\hline São Rafael & 81,5 & 115,1 \\
\hline Sapopemba & 73,0 & 49,6 \\
\hline Saúde & 13,6 & 20,4 \\
\hline Sé & 99,5 & 159,2 \\
\hline Socorro & 33,3 & 71,8 \\
\hline Tatuapé & 20,2 & 20,2 \\
\hline Tremembé & 44,6 & 31,7 \\
\hline Tucuruvi & 22,2 & 20,2 \\
\hline Vila Andrade & 29,2 & 42,4 \\
\hline Vila Curuçá & 80,0 & 54,7 \\
\hline Vila Formosa & 28,8 & 38,4 \\
\hline Vila Guilherme & 26,0 & 32,0 \\
\hline Vila Jacuí & 52,2 & 31,0 \\
\hline Vila Leopoldina & 11,2 & 29,8 \\
\hline Vila Maria & 40,0 & 39,1 \\
\hline Vila Mariana & 16,2 & 19,4 \\
\hline Vila Matilde & 29,3 & 15,6 \\
\hline Vila Medeiros & 52,7 & 39,9 \\
\hline Vila Prudente & 28,4 & 7,8 \\
\hline Vila Sônia & 24,1 & 32,1 \\
\hline Ignorado & - & - \\
\hline Total & 57,4 & \\
\hline
\end{tabular}

A análise da Tabela 14 mostra que a maior parte dos distritos tem o valor dos índices de ocorrência semelhante ao dos coeficientes obtidos segundo o local de residência das vítimas. A principal diferença deve-se à região central da cidade, que apresenta índices com valores ainda maiores que os outros locais, ganhando destaque os distritos da Barra Funda, Bom Retiro, Sé e República, que quase dobram suas taxas quando a incidência por local de residência é comparada com o local de ocorrência.

Inicialmente, é preciso ressalvar que estes distritos possuem populações pequenas; assim, alguns óbitos a mais fazem variar os coeficientes com maior intensidade. Um dos modos de contornar este problema é calcular coeficientes por área, somando as populações dos 
distritos próximos, como é o caso da Sé e República. Quando isso foi feito, ainda assim essas taxas se mantiveram altas.

O cálculo do coeficiente de correlação linear de Pearson para as taxas de mortalidade por homicídios segundo local de residência e o índice de ocorrência mostrou correlação positiva (valor de $r=0,664$ ) entre essas taxas, ou seja, uma está relacionada com a outra (Triola, 1998).

É sabido que o Município de São Paulo exibe diferenças importantes, entre os vários bairros, nas condições de vida de seus moradores, que se refletem nas diferenças nos riscos ou os danos sofridos por eles. Considerase importante agregar aos dados estatísticos o conhecimento de algumas caracteristicas dessas regiões, com vistas a entender as diferenças na forma pela qual a violência urbana se manifesta, para que sejam dirigidos cuidados diferenciados para essas áreas.

No caso dos distritos pertencentes à região central da cidade, esta área corresponde ao chamado centro velho, cujas condições de vida e moradia encontram-se deterioradas, o que não é um fenômeno particular do Município, geralmente ocorrendo em todo grande centro urbano, seja S. Paulo, Rio de Janeiro, Miami ou Nova York.

Nesta área é onde se verifica a maior circulação de pessoas no Município, pela oferta de comércio, transportes, serviços e postos de trabalho, o que por si só poderia contribuir para a elevação do risco, visto que há mais gente exposta nesses locais. Sposatti (200) refere que a cidade tem oferta centralizada de empregos, exemplificando que enquanto a taxa geral de empregos por moradores na cidade é de 0,46 (dados para 1997), o distrito da Sé concentra a maior taxa distrital com 6,80 empregos/habitantes. O distrito da República registra a taxa de 3,15 empregos/habitantes. É certo, portanto, que são regiões onde a população que transita diariamente é muito maior do que a de seus moradores. Além disso as áreas centrais são tipicamente de prestação de serviços com lojas de comércio de roupas a eletrodomésticos, com alguns locais de tradição, sem filiais ou agências em bairros, o que provoca a atração de públicos específicos. Aí também está 
localizada uma grande concentração de ambulantes ilegais que, tradicionalmente, é fonte de conflitos com resolução violenta.

Especificamente o centro velho do Município de São Paulo possui algumas particularidades que merecem ser apontadas, especialmente aquelas que podem estar compondo o leque de relações com as ações violentas. Nesta região estão concentradas em maior número moradias transformados em habitações coletivas, os cortiços. Uma grande parte delas são casarões antigos, cujas famílias, ao empobrecerem, alugaram os cômodos para o maior número possível de pessoas. Em outros casos, com a morte do proprietário, os imóveis foram deixados vazios e sofreram invasões. No centro, algumas dessas moradias oferecem alugueis muito baixos, com pouca fiscalização e precária identificação de seus ocupantes, visto que por vezes não há fichas a serem preenchidas quando do aluguel do cômodo. Por não serem estabelecimentos comerciais, também não sofrem fiscalização do poder público. Além disso, a população, muitas vezes, é flutuante, mudando de endereço constantemente.

Também é onde existe a maior população que vive nas ruas, especialmente na área do Parque D. Pedro, Praças da Sé e República. De acordo com o censo FIPE/SAS/PMS para o ano de 2.000 (Sposati, 2000), no Municipio de São Paulo existem 5.013 moradores de rua, sendo que os distritos que apresentaram o maior número de pessoas nesta situação foram a Sé, com 773 moradores e depois a República com 715.

Em relação ao comércio de drogas, é na área do centro da cidade que localiza-se uma área apelidada de "crackolândia", onde menores perambulavam drogados pelas ruas em plena luz do dia, ora pedindo esmolas, ora praticando pequenos assaltos nos sinais de trânsito. Um estudo, com abrangência nacional, realizado recentemente com meninos e meninas em situação de rua, comprovou que esse grupo é de altíssimo risco para o consumo de uma ampla variedade de substâncias: o uso de solventes e maconha é intenso e freqüente (o crack e a cocaína também são bastante utilizados em capitais como Rio de Janeiro e São Paulo) (Bastos e Carlini- 
Cotrim, 1998). Esses menores, submetidos a condições tão adversas, também são atingidos por doenças, desnutrição e toda a sorte de violências.

Por tudo isso, considera-se importante que o Poder Público viabilize propostas para a recuperação das áreas centrais.

Em relação à zona sul, as informações da Polícia Civil, referem que os problemas de violência nessa área podem estar predominantemente ligados ao tráfico e ação de justiceiros (os chamados grupos de extermínio). Costa (1999) relata uma história que ilustra bem esta situação, a respeito das gangues do "Bronx" e "Ninjas", que atuaram entre 1993 e 1998, no bairro do Jardim Ângela, localizado na zona sul. Em 1992, um ex-policial militar do bairro resolveu montar com adolescentes, uma espécie de "guarda-mirim", ensinando-os a atirar para defender a população da região e, ao mesmo tempo tentando mantê-los afastados do tráfico de drogas. Entretanto, acabou sendo assassinado por um dos integrantes da guarda, que se transformou na gangue do Bronx, que veio a se especializar no tráfico de drogas, cobrança de pedágio de moradores e comerciantes da região. Após a prisão de seus lideres, os "Ninjas", grupo também composto por adolescentes, ocuparam este lugar. Costa (1999) afirma que levantamentos oficiais mostram que essas gangues foram responsáveis pela morte de 156 pessoas naquele período.

Além disso, grande parte das favelas da zona sul da cidade resultou da invasão de áreas de proteção de mananciais. Para Rolnik (1999) tal fato compõe o urbanismo de risco, marcado pela "inseguridade, quer do terreno, quer da construção ou ainda da condição jurídica da posse daquele território". Esses locais normalmente, pelas caracteristicas ambientais, sāo perigosos e dificeis de se ocupar: encostas, beiras de córregos etc. São locais que o mercado imobiliário não quer. "O risco é antes de mais nada do morador: o barraco pode deslizar ou inundar com a chuva, a drenagem e o esgoto podem se misturar nas baixadas - a saúde e a vida são assim ameaçadas. No cotidiano, são as horas perdidas no transporte, a incerteza quanto ao destino daquele lugar, no desconforto da casa e da rua." Para agravar o quadro, por serem áreas que estão legalmente sob proteção 
ambiental, o Estado encontra-se impedido de realizar obras de infraestrutura.

É possivel que as regiões do Jaguaré e Perus tenham indices de ocorrência maiores que os coeficientes de residência em razão da existência de grandes áreas despovoadas, próximas às rodovias, podendo ser regiões de "encontros de cadáver".

Por outro lado, aqueles locais de alto poder aquisitivo, que já apresentavam baixas taxas segundo local de residência e, onde também se verificava uma tendência de queda quando são comparados os dados de 2000 com os de 1996, na distribuição por local de ocorrência, apresentam taxas ainda menores, apontando que os seus moradores quando se expõem, o fazem em outros locais. Esses espaços contam com guardas particulares e, com certeza, com maior vigilância do poder público. Estudo de Akerman \& Bousquat (1999) referem a alocação prioritária de recursos de segurança pública nas áreas mais favorecidas da cidade, onde há predomínio de crimes contra o patrimônio, no caso analisado correspondendo aos furtos de veículos, ao passo que as áreas onde predominam os homicídios recebem menor contingentes policiais e menor número de viaturas por habitantes.

Essas regiões se constituem em oásis nesta triste guerra urbana, reafirmando o caráter altamente segregado dos grandes centros urbanos. Em termos de mortalidade violenta coexistem na cidade, taxas tão diversas quanto as do Canadá e da Colômbia. O único problema é que tal segregação pode levar a mais violência.

Esta é uma das faces do chamado urbanismo de risco (Rolnik, 1999), ao concentrar qualidades em determinados espaços exíguos e impedir que elas sejam compartilhadas por todos. Este é um elemento forte (e comum) na estrutura das cidades brasileiras: a existência de contrastes profundos entre condiçōes urbanas radicalmente distintas, convivendo e conflitando no interior da mesma cidade.

A existência de diferenças regionais nessas taxas de homicídios, também vem sendo verificada em outros trabalhos, sendo que as regiōes 
com maiores taxas de homicidio são aquelas cujas condições sociais são mais desfavoráveis (Barata e col., 1998; Szwarcwald e col., 1999; Gawryszewski \& Mello Jorge, 2000).

Desse modo, considerou-se importante também verificar como outros indicadores (de saúde e socioeconômicos) se comportavam nos diferentes distritos do Municipio de São Paulo. Não foi possivel contar com dados do Censo 2000, visto não terem sido divulgados indicadores para os distritos do município.

Mas, também considerou-se importante destacar os coeficientes para a população de maior risco para estas mortes, que são os indivíduos do sexo masculino com idades de 15 a 29 anos, que tem seus coeficientes quadruplicados em relação aos da população geral. Foram calculados os coeficientes médios de mortalidade para os anos de 1999 e 2000, visando diminuir possiveis flutuações (Figura 17) que podem ocorrer de um ano para outro.

O coeficiente de mortalidade por homicidios para faixa de 15 a 29 anos é 4,3 vezes o valor encontrado para a população geral, porém alguns distritos apresentam valores ainda maiores, como é o caso da Lapa $(8,8)$, Tucuruvi $(8,8)$ Rio Pequeno $(7,9)$, Campo Limpo $(7,0)$ Consolação $(6,0)$, Casa Verde $(6,4)$, Pari $(6,0)$, e o Morumbi $(5,4)$. Alguns deles mudam suas faixas de risco para a população jovem. No Jardim Paulista, nesta faixa não foi registrado nenhum óbito.

A Figura 18 apresenta a taxa de mortalidade infantil segundo distritos do Município para o ano 2000 (SEADE, 2000), podendo ser observado que também a maior parte dos distritos de altíssimo risco, exceto $\mathrm{S}$. Mateus e Guaianazes, apresenta taxas de mortalidade infantil acima da média do Município de São Paulo, 15,8/1000 nascidos vivos. O coeficiente de correlação linear de Pearson para as taxas de mortalidade por homicidios segundo local de residência e mortalidade infantil mostrou correlação positiva, mas com um valor baixo, $r=0,391$. Também Szwarcwald e col. (1999), ao estudarem a associação entre condições de saúde e 
desigualdade de renda no Municipio do Rio de Janeiro, utilizando técnicas de regressão múltipla, mostrou justamente a mortalidade infantil como o indicador menos correlacionado com o nível de desigualdade de renda. Esta taxa perdeu sensibilidade como indicador de nivel de saúde, visto que é influenciada pelo aumento na oferta de serviços, atenção ao parto e saneamento, por exemplo.

A Figura 19 mostra o Mapa da Exclusão/Inclusão Social (Sposati, 2000), construído a partir de vários indicadores, que foram classificados em quatro categorias: autonomia, qualidade de vida, desenvolvimento humano (no qual estão os homicídios) e eqüidade. Foram atribuídos valores, que vão de menos um (excluidos) até um (incluídos). Encontram-se entre os que foram considerados os mais excluídos, em ordem decrescente, os distritos de Jardim Ângela, Parelheiros, Grajaú, Iguatemi, Jardim S. Luis, Lajeado, Guaianazes, Cidade Tiradentes, Itaim Paulista e Capão Redondo. Entre os que apresentam os maiores valores positivos estão Jardim Paulista, Consolação, Pinheiros, Moema, Vila Mariana, Perdizes, Santa Cecília, Itaim Bibi e Alto de Pinheiros.

O coeficiente de correlação linear de Pearson para as taxas de mortalidade por homicidios segundo local de residência e índices de exclusão social mostrou correlação negativa, com valor alto ( $r=$ menos 0,78 ), mostrando forte associação entre esses dois eventos. Ressalva-se, entretanto, que este dado não pode ser muito valorizado do ponto de vista estatístico, em razão do coeficiente de mortalidade por homicídios estar englobado nos cálculos daquele indice.

A renda média familiar é mostrada na Figura 20 (Sposatti, 2000), sendo expressos em salários mínimos, ano de 1997, ilustrando bem, a concentração de renda na capital, visto que a maior parte dos distritos apresenta renda média nos níveis mais baixos (50 distritos), localizados na área periférica da cidade. Neste patamar, encontram-se todos os distritos de altíssimo risco, sem exceção. Com os valores mais altos contam-se somente seis distritos, concentrados principalmente na zona oeste da cidade. A maior renda está em Moema (quase 41 salários mínimos) e a menor está em 
José Bonifácio (4,64 salários mínimos - SM). O padrão básico da renda da cidade foi considerado 14 salários. Por esse padrão 20 distritos estão em situação de inclusão e 54 distritos em situação de exclusão.

O coeficiente de correlação de Pearson para as taxas de mortalidade por homicídios segundo local de residência e renda média mostrou correlação negativa com valor de $r=$ menos 0,744 . O distrito do Morumbi foi retirado dos cálculos por ser considerado out-lier (definido como ponto extremo, muito afastado dos demais, visto apresentar alta renda e ao mesmo tempo, risco alto para homicídios). Esse distrito apresenta algumas particularidades que merecem ser assinaladas: tradicionalmente abriga mansões para uma população de alto poder aquisitivo e possui ainda, áreas desabitadas, o que permite ao mesmo tempo a ampliação da ocupação por favelas e um número expressivo de lançamentos imobiliários de alto padrão.

A forte correlação negativa encontrada não indica de forma alguma causalidade, mas que variações para mais na renda média pode determinar variações para menos na mortalidade por homicidios. Para melhor descrever essa relação utilizou-se uma curva ajustada não linear (no caso, a curva exponencial foi a que apresentou o maior coeficiente de determinação), mostrada na Figura 21. O formato da curva já permite observar que as variações em uma das variáveis vão determinar maiores variações na outra variável entre os niveis de renda menores, mas quando os níveis de renda atingem valores em torno de 25 salários mínimos ou mais as variações na mortalidade já não são assim tão consideráveis. Tão somente a título de exemplo, foi realizada uma projeção dos valores da mortalidade por homicídios a partir de aumentos na renda. $O$ acréscimo de um salário nos locais em que a renda média é de dez salários mínimos pode fazer decrescer em 330 as mortes por homicídios, enquanto que o mesmo acréscimo em locais com renda média de trinta salários o ganho de vidas seria de 90. 


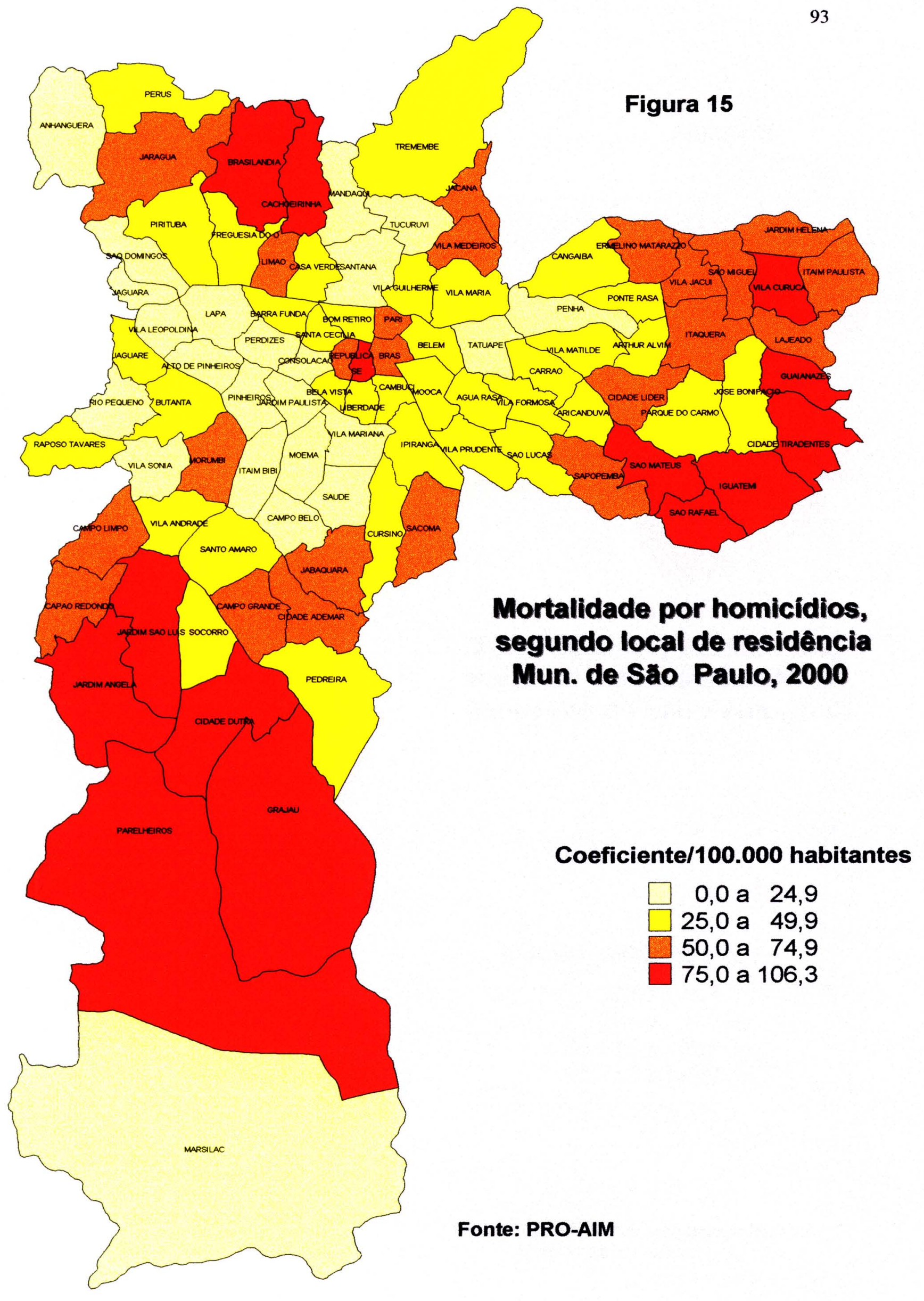




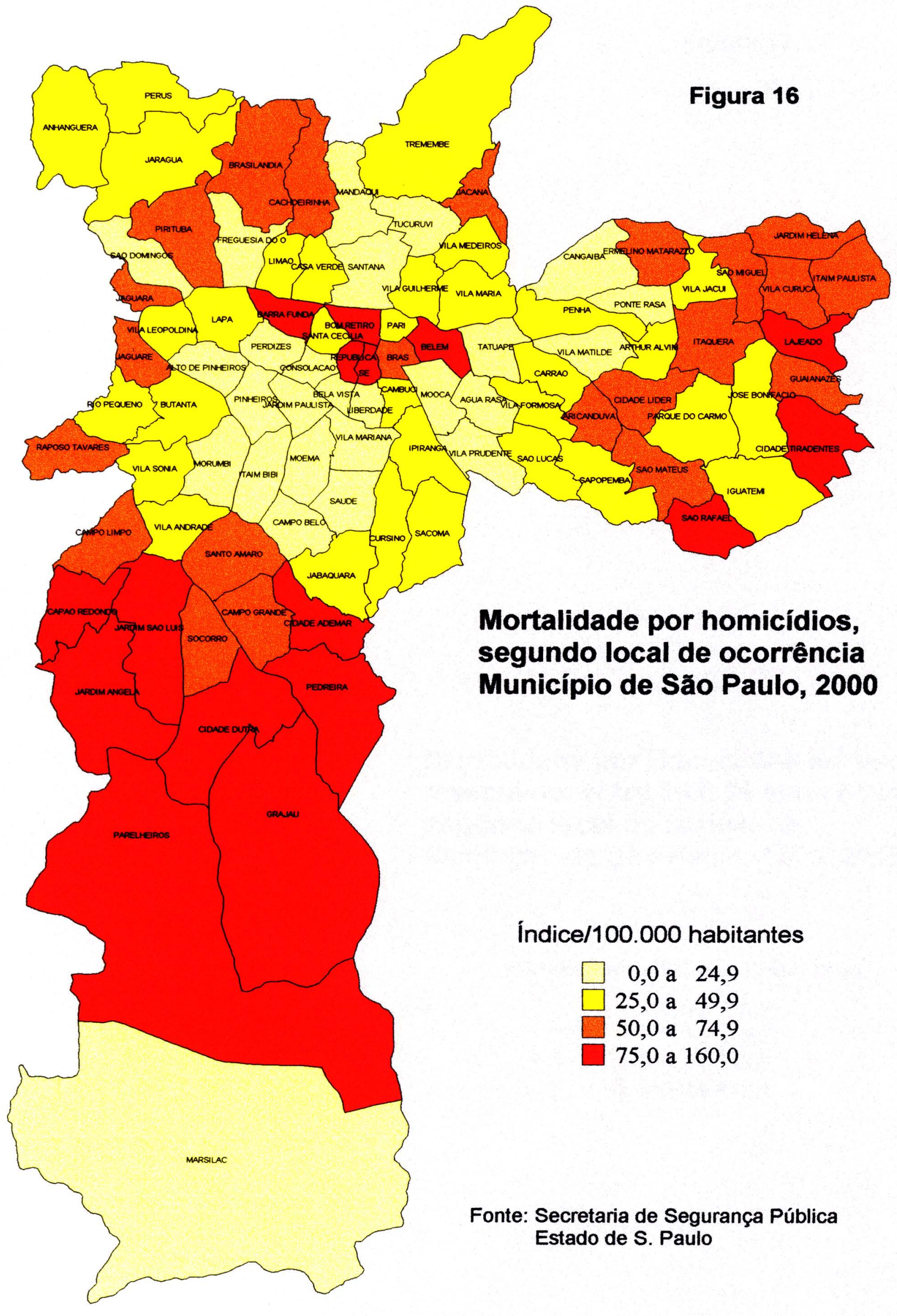




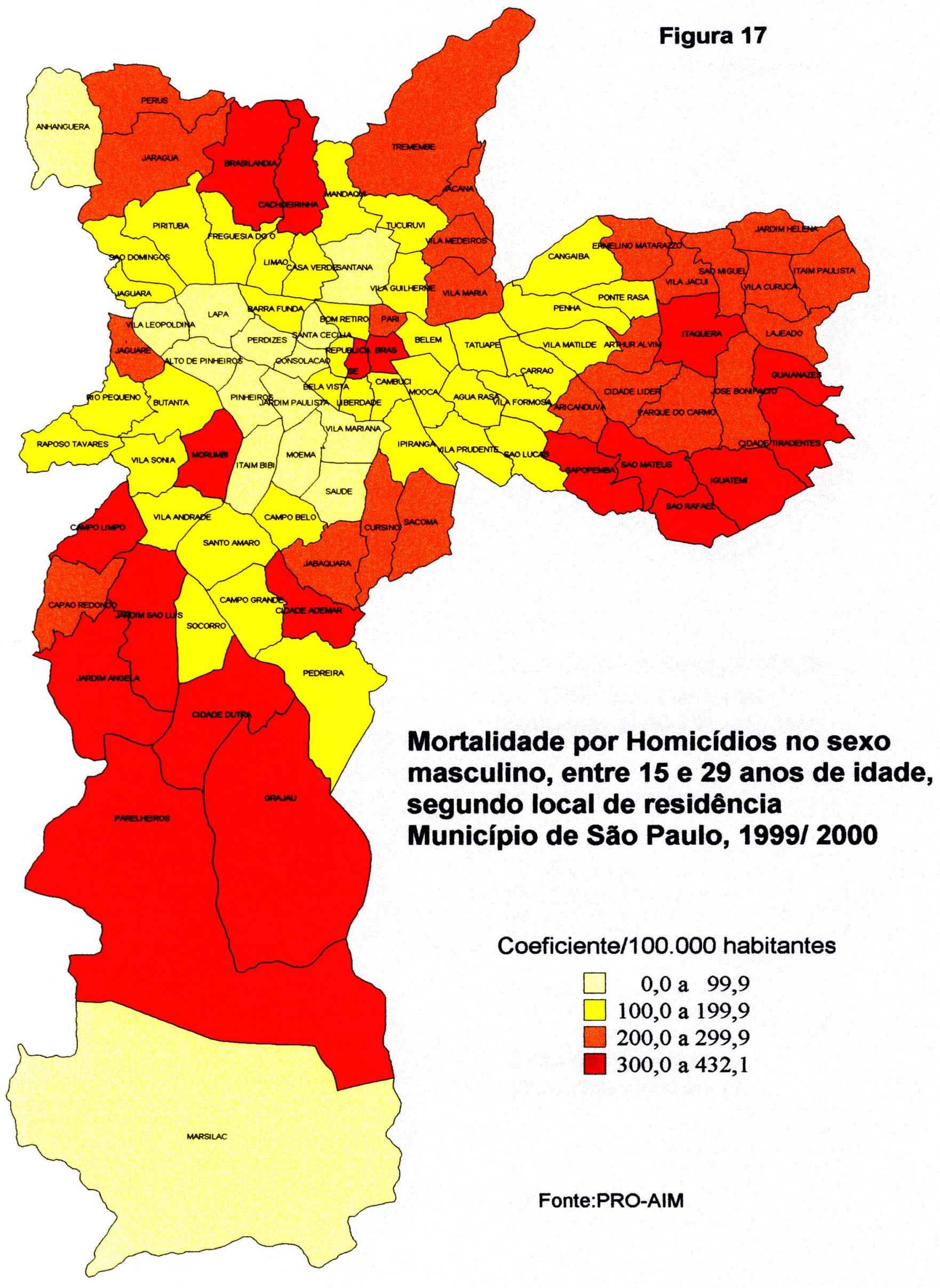




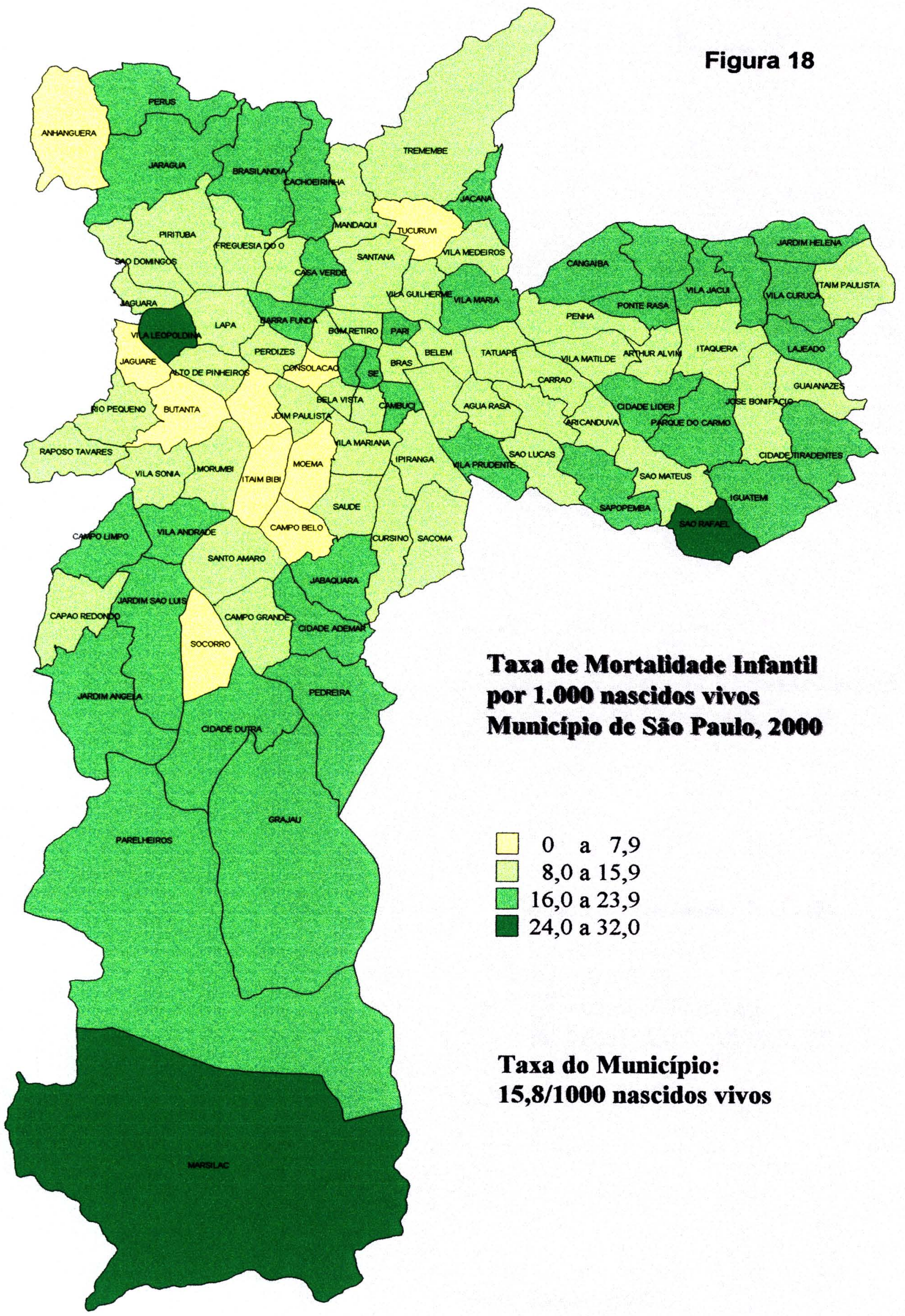

Fonte: Fundação SEADE 


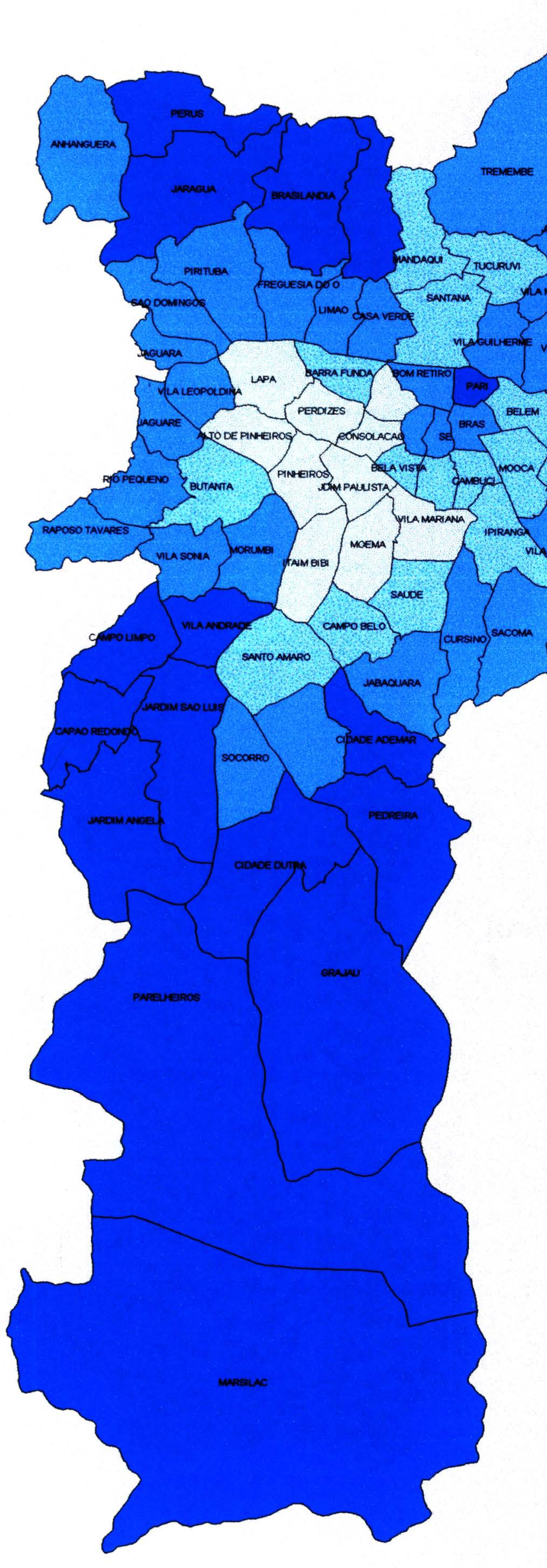

Figura 19

\section{Mapa da Exclusão/ Inclusão Social Município de São Paulo, 2000}

\section{Índice de Exclusão/ Inclusão}

$\square 0,5$ a 1,0

$\square, 0$ a 0,49

$\square$ menos 0,50 a 0,01

menos 1,0 a menos 0,49

Fonte: Sposatti, 2000 


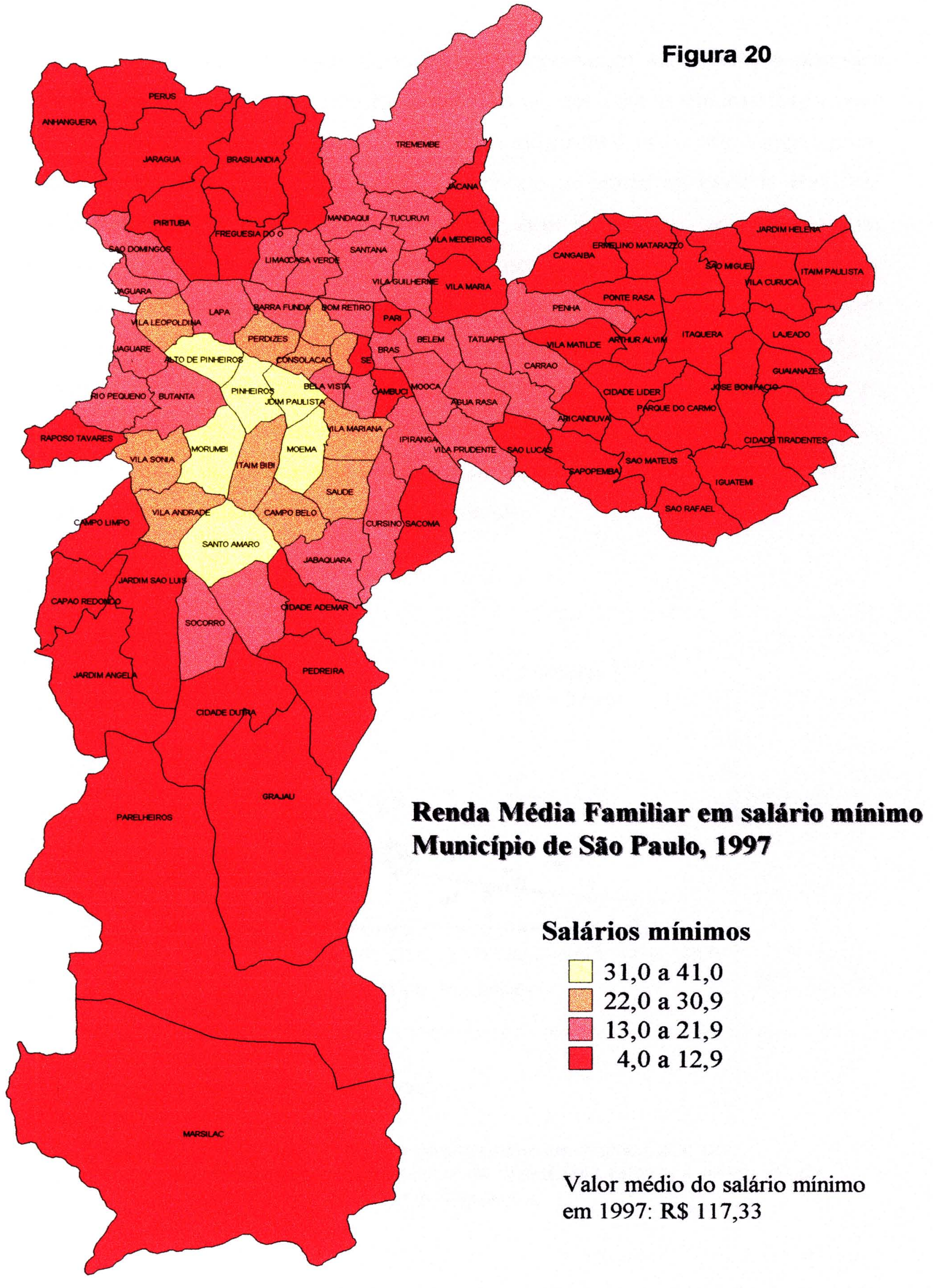

Fonte: Sposatti, 2000 
A esse respeito duas considerações merecem ser feitas, a primeira delas é que a correlação obtida, pode não se dar com a mesma força para outros locais como por exemplo, o Piauí. A segunda é que esta relação pode estar sendo afetada por variáveis de contexto: a oferta de bens e serviços, meio ambiente físico e social. É possível que nas áreas de menor poder aquisitivo também haja menor policiamento, iluminação pública, oferta de transporte coletivo, o trajeto residência-trabalho seja mais longo fazendo com que as pessoas sejam mais expostas à violência. $\mathrm{E}$ ainda, considerando a hipótese de que o aumento da violência esteja principalmente ligado ao crime organizado em torno do tráfico de drogas, é possível que este tenha mais facilidade de se instalar em áreas onde a presença do Estado é menor, coincidindo com estas áreas de menor renda.

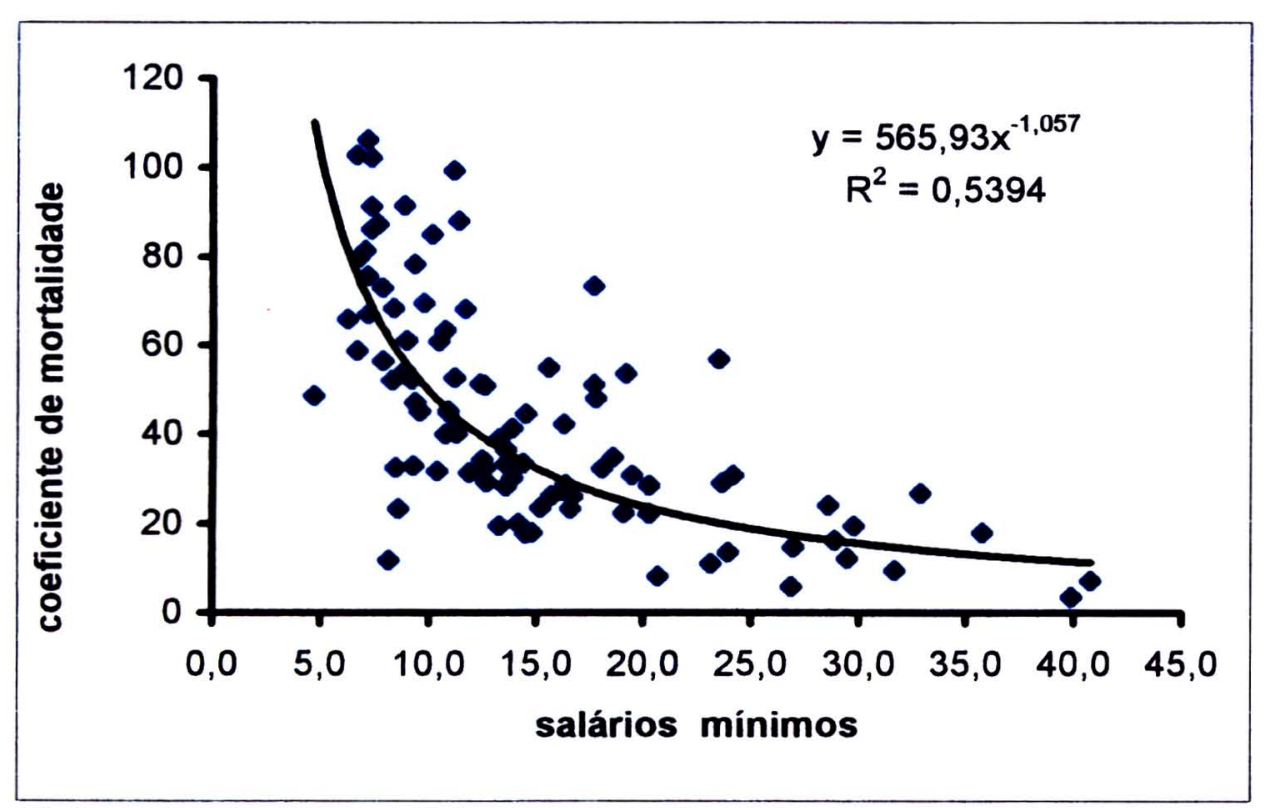

Fonte: Renda média (Sposatti, 2000)

Figura 21: Curva ajustada para coeficientes de mortalidade por homicídios segundo local de residência (2000) e renda média (1997). Município de S. Paulo.

Em resumo, a observação dos mapas mostra a coincidência espacial entre os piores indicadores sócio econômicos e taxas altas de mortalidade 
por homicídios, o que foi também demonstrado pelo cálculo do coeficiente de correlação de Pearson. Os valores desses indicadores são mostrados em tabela anexa.

Drumond Jr. \& Barros (1999) demonstraram que a distribuição desigual da mortalidade do adulto na cidade de São Paulo também se dá para as outras causas. Esses autores utilizaram divisão espacial em áreas homogêneas (em número de quatro), sendo que a área um era aquela composta pelos distritos com melhores condições socioambientais, nos quais viviam $9,5 \%$ da população. $\mathrm{Na}$ área 4 , cujos distritos apresentavam as piores condições, viviam $43,5 \%$. Entre as diferenças mais significativas, foram encontradas a AIDS, liderando as causas de morte na área $1 \mathrm{e}$, nas áreas 3 e 4, o alcoolismo e as doenças hipertensivas surgem como causas importantes. Entre as mulheres, o câncer de mama é a principal causa na área 1 e vai perdendo a importância nas outras áreas. Com certeza, os homicídios mostram diferenças importantes entre as regiōes, visto que na área 4 chegam a representar quase um quarto do total.

\subsection{Informações obtidas a partir dos Inquéritos Policiais}

Dos 5978 homicídios ocorridos no Município de São Paulo, 2202 $(36,8 \%)$ foram encaminhados ao DHPP, em razão de que a autoria do crime não era conhecida. Entre estes, as informaçōes acerca dos 648 casos $(29,4 \%)$ cujos inquéritos já tinham sido encerrados foram analisadas, visando conhecer em que medida essa fonte poderia contribuir para esclarecer melhor o perfil das vítimas, além de conhecer também algumas características do agressor. Os dados foram coletados pelas equipes do DHPP e disponibilizadas para análise nesse estudo.

Ressalva-se que as informaçōes obtidas para esses casos não devem ser extrapoladas para o universo dos homicídios, pois devem existir diferenças entre as características dos óbitos estudados e o total. Lima 
(2000) refere que "provavelmente, nos crimes de autoria conhecida envolvem com maior intensidade pessoas próximas e até mesmo da mesma família, eles não são premeditados, ou seja, acontecem no ápice de um conflito qualquer, de um drama familiar ", enquanto aqueles de autoria desconhecida podem estar ligados à criminalidade. Além disso, correspondem a $10,8 \%$ do total de óbitos por homicídios ocorridos no ano e não obedecem a critérios amostrais.

A Figura 22 foi construída para avaliar se esses crimes demonstravam diferenças importantes em relação ao universo dos homicídios ocorridos no ano 2.000, segundo a idade, não tendo sido observadas diferenças consideráveis. A moda da idade encontrada para estes óbitos foi 19 anos enquanto para o total de óbitos foi 20 anos.

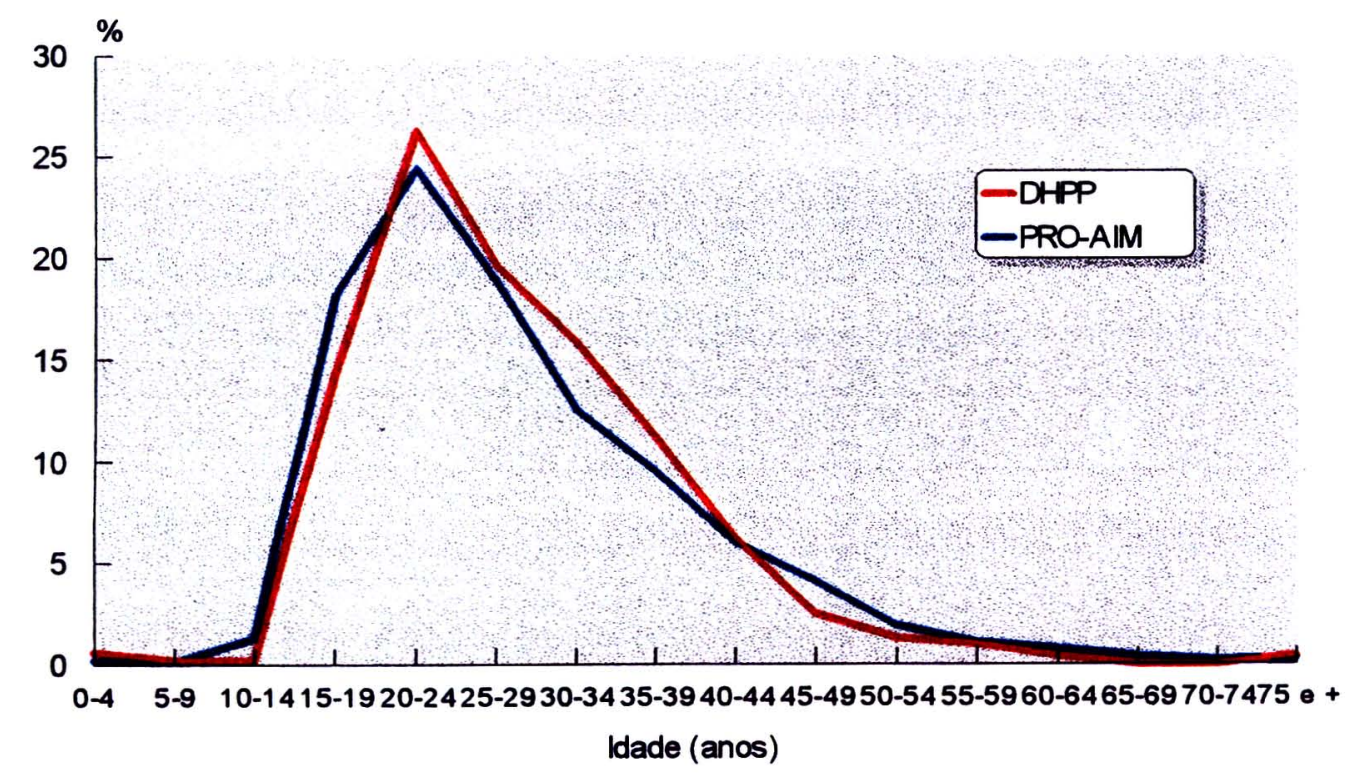

Figura 22: Vítimas de homicídios segundo faixa etária (\%) segundo diferentes fontes de dados. Município de S. Paulo, 2000. 
Também deve ser lembrado que as informações sobre as variáveis são colhidas a partir das respostas prestadas por parentes, vizinhos ou conhecidos das vítimas, que foram arrolados no inquérito.

Apesar das limitações apresentas e confirmando o que foi pensado inicialmente, as informações produzidas podem ajudar na compreensão do problema, sendo que algumas delas acompanham os dados levantados na literatura. Em sua maioria, as vitimas são jovens. Em relação à cor, foram classificados como brancas $50 \%$ delas; seguidas das pardas, $34,1 \%$ e negras $11,6 \%$. Em sua maioria, são naturais de São Paulo $(53,4 \%)$, seguidos dos baianos $(13,3 \%)$, pernambucanos $(8,7 \%)$ e mineiros $(6,1 \%)$.

Os inquéritos permitiram conhecer algumas caracteristicas pessoais dessas vitimas com maior detalhe, como é o caso do estado civil. Para a Declaração de Óbito o que vale é o estado civil oficial da vítima, mas é sabido que uma parte não desprezível da população vive em uniões não legalizadas (Tabela 15).

Tabela 15:

Vítimas de homicídios segundo estado civil $\left(n^{\circ}\right.$ e \%). Municipio de São Paulo, 2000.

\begin{tabular}{lcc}
\hline \multicolumn{1}{c}{ Estado civil } & No. & $\%$ \\
\hline Solteiro & 373 & 57,6 \\
Casado & 75 & 11,6 \\
União consensual & 129 & 19,9 \\
Separada & 19 & 2,9 \\
Viúva & 5 & 0,8 \\
Ignorado & 47 & 7,3 \\
\hline Total & 648 & 100,0 \\
\hline Fonte: Inquéritos Policiais encerrados, investigados pelo DHPP (dados brutos)
\end{tabular}

A maioria dessas vitimas se encontrava desempregada quando ocorreu $O$ ato violento e possuía baixa instrução. Um pouco mais que a metade, $51,7 \%$, não estava empregada quando foi morta (Tabela 16). Apenas sete $(1,1 \%)$ deles haviam cursado o ensino superior, enquanto quase a metade, $44,3 \%$, não havia completado o ensino fundamental (Tabela 
17). Somados os que completaram este grau do ensino esse percentual chega a $53,7 \%$. Atualmente, no mercado de trabalho formal, mesmo as funções mais simples requerem algum grau de instrução. E o mercado de trabalho vem experimentando constantes mudanças. Pode ser citado como exemplo a atividade profissional de "boy", que empregava especialmente o jovem pobre, e que vem sofrendo retração, em parte pela diminuição da atividade econômica, mas principalmente devido ao aumento das formas e velocidade da comunicação, tais como fax, correio eletrônico, contas que podem ser pagas em débito automático nos bancos ou pela Internet.

Tabela 16:

Vítimas de homicídios segundo situação de emprego ( $n^{\circ}$ e \%). Município de São Paulo, 2000.

\begin{tabular}{llc}
\hline Situação de emprego & No. & $\%$ \\
\hline Empregado & 134 & 20,8 \\
Desempregado & 335 & 51,7 \\
lgnorado & 179 & 27,5 \\
\hline Total & 648 & 100,0 \\
\hline
\end{tabular}

Fonte: Inquéritos Policiais encerrados, investigados pelo DHPP (dados brutos)

Tabela 17:

Vítimas de homicidios segundo escolaridade da vítima $\left(n^{\circ} \mathrm{e} \%\right)$. Municipio de São Paulo, 2000.

\begin{tabular}{lcc}
\hline \multicolumn{1}{c}{ Escolaridade } & No. & $\%$ \\
\hline Analfabeto & 27 & 4,2 \\
Alfabetizado & 131 & 20,2 \\
Ensino fundamental incompleto & 129 & 19,9 \\
Ensino fundamental completo & 61 & 9,4 \\
Ensino médio incompleto & 47 & 7,3 \\
Ensino médio completo & 26 & 4,0 \\
Ensino superior & 7 & 1,1 \\
Ignorado & 220 & 34,0 \\
\hline Total & 648 & 100,0 \\
\hline
\end{tabular}

Fonte: Inquéritos Policiais encerrados, investigados pelo DHPP (dados brutos)

Esta baixa escolaridade parece não ser uma situação particular para as vitimas de homicidios, pois também foi encontrada nos condutores de 
veículos de acidentes de trânsito fatais em 1999 (CET, 2001). Quase a metade desses condutores não tinha o primeiro grau completo $(46 \%)$, um quarto deles tinha $\circ 2^{\circ}$ grau ou mais e somente $4 \%$ tinham ensino superior. Chamou a atenção o fato de $6 \%$ serem analfabetos, o que os impediria de dirigir.

Também Carvalho (2002) observou em pacientes admitidos em setor de emergência que a maior proporção deles não tinha escolaridade ou não completou o primeiro grau, não observando diferença estatisticamente significativa entre os diferentes tipos de causas externas.

\section{- Em relação ao uso e tráfico de substâncias psicoativas}

As Tabelas 18 e 19 serão analisadas em conjunto. Para um pouco menos da metade destes óbitos $(41 \%)$, há referências, nos inquéritos, da utilização de substâncias psicoativas. Entre esses, o álcool é a mais freqüentemente registrada $(42,5 \%)$. Em relação ao uso do álcool, é preciso considerar que não sendo substância ilegal, pode ser utilizada em quantidade e freqüência variadas. Cabe lembrar que nesta pesquisa o exame toxicológico realizado pelo IML nas vítimas do período de abril, maio e junho de 2000 , excluídas aquelas cujo exame não foi solicitado, o uso de álcool foi identificado em $38,4 \%$ delas, percentual muito próximo ao encontrado nesta fonte.

A maconha foi a segunda droga mais referida, $22,1 \%$, seguida do crack, $11,7 \%$. Ambas são substâncias mais baratas que a cocaína, por exemplo, sendo mais acessiveis para populações de baixa renda. Considerase que, em relação às substâncias ilegais, a informação possa ser mais precisa. 
Tabela 18:

Vítimas de homicídios, segundo uso de substâncias psicoativas ( ${ }^{\circ}$ e \%). Município de São Paulo, 2000.

\begin{tabular}{|c|c|c|}
\hline Uso & No. & $\%$ \\
\hline Sim & 266 & 41,0 \\
\hline Não & 40 & 6,2 \\
\hline Ignorado & 342 & 52,8 \\
\hline Total & 648 & 100,0 \\
\hline
\end{tabular}

Fonte: Inquéritos Policiais encerrados, investigados pelo DHPP (dados brutos)

Tabela 19:

Vitimas de homicidios, segundo tipo de substância psicoativa ( $n^{\circ}$ e \%). Município de São Paulo, 2000.

\begin{tabular}{lcc}
\hline \multicolumn{1}{c}{ Substância } & No. & $\%$ \\
\hline Álcool & 113 & 42,5 \\
Maconha & 59 & 22,1 \\
Crack & 31 & 11,7 \\
Múltiplas drogas & 38 & 14,3 \\
Cocaína & 18 & 6,8 \\
Outros & 1 & 0,4 \\
lgnorada & 6 & 2,2 \\
\hline Total & 266 & 100,0 \\
\hline
\end{tabular}

Fonte: Inquéritos Policiais encerrados, investigados pelo DHPP (dados brutos)

Obs: Excluídos os 342 casos de não usuários e aqueles cuja informação era ignorada

Para verificar se essas vítimas tinham apresentado situação de conflitos com a lei, foram utilizadas as informações a respeito da existência de antecedentes criminais nos inquéritos (Tabela 20), que é feita a partir de consulta aos registros do sistema informatizado da polícia civil, por já terem se envolvido em inquéritos ou processos penais, não significando, entretanto, que já tenham sido julgadas.

Esses resultados revelaram uma proporção de $31,5 \%$ de vítimas que possuíam antecedentes criminais. Para não dividir termos utilizados pela área da segurança pública e que podem ter conotações legais, propõe-se denominar esta situação como "indivíduos em conflito com a lei". 
Tabela 20:

Vítimas de homicidios segundo situação de conflito com a lei $\left(n^{\circ}\right.$ e \%). Município de São Paulo, 2000.

\begin{tabular}{lcc}
\hline \multicolumn{1}{c}{ Conflito com a lei } & No. & $\%$ \\
\hline Não & 375 & 57,9 \\
Sim & 204 & 31,5 \\
Ignorado & 69 & 10,6 \\
\hline Total & 648 & 100,0 \\
\hline
\end{tabular}

Fonte: Inquéritos Policiais encerrados, investigados pelo DHPP (dados brutos)

No decorrer da pesquisa nos $\mathrm{BO}$, notou-se uma certa freqüência de referências à existência de situações de conflito com a lei para as vítimas (no item "histórico" desses $\mathrm{BO}$ ). No entanto, como não havia sido previsto não era mais possivel coletar esta informação no BO.

Outros pesquisadores também verificaram essa relação. Adorno (1999), citando dados de trabalhos realizados no Núcleo de Estudos da Violência da Universidade de São Paulo, observa que, em cada três jovens vítimas de homicídio, um era agressor. Mas, o autor cita esse dado chamando a atenção que é maior a vitimização do jovem do que a autoria.

Percentuais próximos a esse, foram encontrados em estudo realizado no Estado da Pensilvânia, EUA, para o ano de 1993 (Miller e col, 2001). Do total de crimes ocorridos naquele Estado, em $25 \%$ dos casos os jovens atuaram como vítimas e agressores. Estes autores também ressaltaram que o problema da violência contra crianças e adolescentes é muito maior que a cometida pelos jovens. Em sua maioria (72\%), esses crimes ocorreram na área urbana.

Dados acerca dos homicídios ocorridos na Sexta Seccional da Polícia $\mathrm{Civil}^{8}$ (região de Santo Amaro, zona sul da cidade) para o período de março, abril e maio de 2001 mostraram percentuais menores, visto que 19\% das vitimas possuiam antecedentes criminais. Entre os artigos penais mais freqüentes constaram o artigo 115 (furto), artigo 157 (roubo) e artigo 10

\footnotetext{
${ }^{8}$ Informação pessoal.
} 
(posse de arma). Os homicidios foram responsáveis por $6 \%$ dos antecedentes; a posse e tráfico de drogas somaram juntas $15 \%$.

No Recife, um estudo caso-controle (Falbo e col, 2001) com vítimas de homicídios do sexo masculino com idades entre 15 e 19 anos (casos), foram pareados com vizinhos que tinham o mesmo sexo e idade (grupo controle) e os resultados apontaram que a existência de histórico de registros policiais e uso de drogas ilicitas, entre outros, foram identificados como fatores de risco para mortes por homicidios. Entre os fatores protetores os autores encontraram nivel de educação alto, práticas religiosas e presença do pai na casa.

É preciso apontar o problema, mas ter muito cuidado na interpretação desse dado. Devido à grande preocupação que este tema representa hoje para a sociedade, muitas vezes incorre-se em exageros político-ideológicos, que trazem de volta à cena velhas e novas propostas, tais como a adoção da pena de morte ou a redução da idade de responsabilidade penal para 16 anos. Ao contrário, trata-se aqui, de um trabalho realizado no âmbito da saúde pública, de discutir os fatores que vão compor o perfil dos grupos vulneráveis que devem merecer politicas públicas de prevenção e proteção à saúde urgentes.

Em relação à motivação desses crimes (apresentados na Tabela 21), do mesmo modo que nos $\mathrm{BO}$, foi verificado que a maioria deles está classificada na categoria dos ignorados, 73\%. Mas entre mortes cuja investigação identificou um motivo, o primeiro lugar foi ocupado pelos crimes relacionados ao uso e tráfico de droga $(41,5 \%$ - excluídos aqueles considerados ignorados), seguindo-se as vinganças $(21,3 \%)$, os motivos fúteis/conflitos interpessoais $(12,8 \%)$ e os latrocínios $(11,6 \%)$. Isso reforça a hipótese inicial de que, entre os crimes de autoria desconhecida, estejam aqueles ligados ao tráfico, grupos de extermínio, em suma, aqueles relacionados com a criminalidade organizada. 
Tabela 21:

Vítimas de homicidios Segundo motivo do evento ( $n^{\circ} \mathrm{e} \%$ ). Município de São Paulo, 2000.

\begin{tabular}{lcc}
\hline \multicolumn{1}{c}{ Motivação } & No. & $\%$ \\
\hline Relacionado com drogas & 68 & 41,5 \\
Vingança & 35 & 21,3 \\
Conflitos interpessoais & 21 & 12,8 \\
Latrocinio & 19 & 11,6 \\
Divida/ disputa financeira & 8 & 4,9 \\
Passional & 7 & 4,2 \\
Outros & 6 & 3,7 \\
\hline Total & 164 & 100,0 \\
\hline
\end{tabular}

Excluídos os 472 casos ( $73,0 \%$ do total), cujo motivo foi ignorado

\section{- Alguns aspectos acerca do perfíl dos agressores}

Atualmente, poucos trabalhos são realizados para conhecer o perfil dos autores de crimes, especialmente a área da saúde que trabalha principalmente com os dados acerca da vítima. Por isso, considerou-se relevante apresentar alguns dados obtidos. Ressalva-se novamente que as informações obtidas para esses casos não devem ser extrapoladas para o universo dos homicidios, visto representarem somente $1,5 \%$ do total de óbitos ocorridos no ano e não obedecerem a critérios amostrais (não é possivel determinar se há diferenças entre esses inquéritos encerrados e os que ainda não o foram).

Foram analisadas as informações referentes a 94 autores $(14,5 \%$ dos inquéritos encerrados). É possível que exista um número um pouco maior de autores identificados, cujos inquéritos ainda não estão encerrados. Segundo informações obtidas, podem ser estes inquéritos com autoria os que são retidos por mais tempo com a finalidade de juntar o maior número de provas possiveis antes de ser encaminhados para a Justiça. Certamente, também contribuiu para isso, o tempo em que foi encerrada esta parte da pesquisa, final de julho de 2001 , considerado tempo pouco suficiente para elucidar os 
casos dos últimos meses do ano 2.000. Dados de Lima (2000) para o ano de 1995, mostraram um percentual um pouco maior de casos solucionados $(29,3 \%)$ no DHPP (não foi possivel conhecer o intervalo de tempo entre o início/término dessa pesquisa e o ano pesquisado).

Entre os agressores o sexo masculino foi predominante, visto que foram identificados como agressores 93 homens (98,9\%) e 1 mulher $(1,1 \%)$. Esta é uma verificação comum, visto que dados do próprio DHPP (1998 e 1999), para anos anteriores, também mostraram que as mulheres agressoras participam sempre com percentuais baixos, pois, em 1996 e 1997, foram responsáveis também por $1 \%$. Percentual mais alto foi encontrado em 1998 , quando chegou a $7 \%$.

Em relação às idades, a maior parte dos autores identificados no ano de 2000 , é um pouco mais jovem que suas vítimas, pois a metade pertencia à faixa de 15 a 24 anos (52,1\%; enquanto que o percentual de vítimas com idade até 24 anos somaram 44,1\%). A faixa que apresentou a maior freqüência foi de 15 a 19 anos $(28,7 \%)$, sendo que a moda foi 19 anos, coincidindo com a das vítimas pesquisadas nos inquéritos. Chama atenção o fato que a idade de 17 anos ocupou o segundo lugar em freqüência.

Como anteriormente mencionado, a literatura não é farta a este respeito, a maioria dos trabalhos privilegia o estudo das vítimas e não dos autores. No estudo acerca do perfil do réu nos delitos contra o patrimônio (furto e roubo ${ }^{9}$ ) foi realizado pelo Centro Brasileiro de Estudos e Pesquisas Judiciais (CEBEPEJ, 2000), através do levantamento de amostra de processos do período de 1991 a 1999. Nesta pesquisa, observou-se também que os autores desses delitos pertencem ao grupo dos jovens do sexo masculino. A predominância masculina foi verificada nos dois tipos de crime, manifestando-se de forma mais expressiva no roubo (97\%). Os jovens de 18 a 21 anos, responderam por quase a metade dos dois delitos: $44 \%$ do total dos envolvidos em roubo e $35 \%$ dos processados por furto. Apenas $25 \%$ dos acusados por furto e $15 \%$ por roubo têm mais de 30 anos. Este trabalho, ao

\footnotetext{
${ }^{9}$ No furto a subtração se dá sem violência ou grave ameaça, enquanto que no roubo é mediante violência e grave ameaça.
} 
comparar as idades dos réus com os dados populacionais (utilizando o censo de 1991), mostrou que, enquanto na população geral a faixa de 18 a 21 anos contribuia com $11 \%$ do total da população, a proporção de réus nesta mesma faixa era $42 \%$, ou seja 3,8 vezes maior que a constatada no censo. Com o avançar da idade esta situação já se inverte, pois se $13 \%$ dos réus tinham de 31 a 40 anos, na população geral eles eram $28 \%$.

Esses agressores são brancos, em sua maioria (45,7\%), seguidos dos pardos $(36,2 \%)$ e depois dos negros $(9,6 \%)$. O estudo com os réus nos delitos contra o patrimônio (CEBEPEJ, 2000) revelou resultados próximos a este, visto que individuos de cor branca eram a maioria, $57 \%$ (no entanto a freqüência de brancos na população geral, utilizando dados do censo 1991, era maior, cerca de $70 \%$ ). Os pardos eram $31 \%$ (na população representavam $22 \%$ ) e $12 \%$ de negros (na população, representavam $4 \%$ ). Enfim, quando são analisados os dados brutos, embora os brancos sejam realmente a maioria, eles estão menos representados proporcionalmente em relação à população geral, enquanto com os indivíduos pardos e negros ocorre o inverso.

Apesar do mito da democracia racial brasileira, sabe-se que os negros estão entre os individuos com piores indicadores de renda, emprego e escolarização. Segundo dados do Instituto de Pesquisa Econômica Aplicada (IPEA), divulgados na I Conferência Nacional contra o Racismo e a Intolerância, realizada no Rio de Janeiro em agosto de 2001, os negros são maioria entre os pobres e indigentes. Encontram-se, também, fora do centro do poder, pois nos poderes Executivo, Legislativo e Judiciário, a presença deles é mínima ${ }^{10}$. Numa sociedade em que, historicamente, se associa de forma espúria crimes à pobreza, os negros parecem ser duplamente discriminados.

Comparados às vítimas quanto ao estado civil, observa-se que também a maior parte dos agressores era formada por solteiros $(60,6 \%)$, diminuindo o percentual de casados $(5,3 \%)$, enquanto cresciam as uniões consensuais $(29,8 \%)$. 
A semelhança entre o perfil das vítimas e dos agressores também se dá em relação à situação de emprego (Figura 23), pois do mesmo modo que suas vítimas a maioria encontrava-se desempregada: $51,1 \%$. Também no perfil dos réus de furto e roubo (CEBEPEJ, 2000), 60\% revelaram estar desempregados no momento do delito.

\section{Vítima}

\section{Agressor}

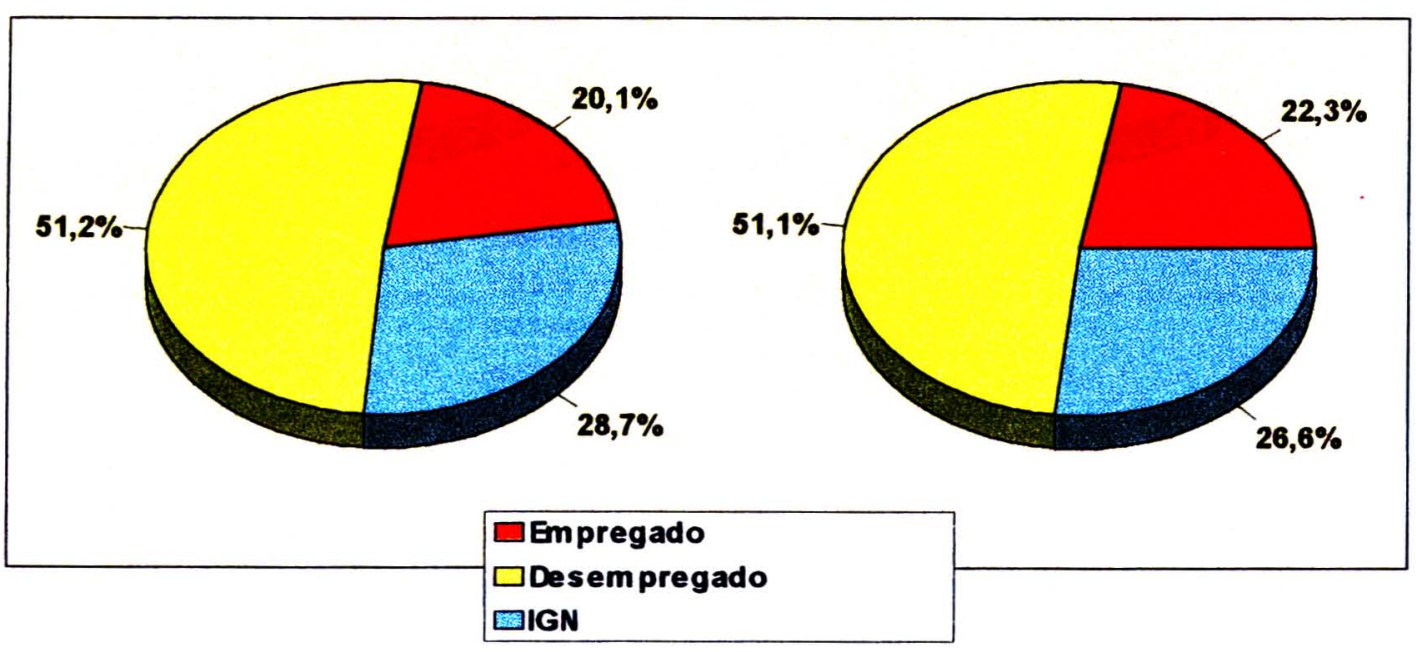

Figura 23:

Vítimas e agressores segundo situação de emprego. Inquéritos encerrados no DHPP. Municipio de São Paulo, 2000.

Os agressores também possuem baixa escolaridade, com percentuais um pouco mais desfavoráveis que o grupo de vítimas, pois $60,6 \%$ têm até o ensino fundamental completo. Neste grupo, cresce o número de analfabetos que chega a $10,6 \%$. Cabe ressaltar que os dados populacionais do Censo 2000 mostram que a taxa de alfabetização na população residente de 10 anos ou mais, no Município de São Paulo, é de 95,4\% (IBGE, 2002), ou seja menor do que a verificada entre os agressores. Ninguém referiu possuir

\footnotetext{
${ }^{10}$ Jornal do Brasil. Primeiro Caderno, em 26 de agosto de 2001.
} 
diploma de nível universitário. A Figura 24 compara vítimas e agressores segundo condição de escolaridade.

\section{Vítima}

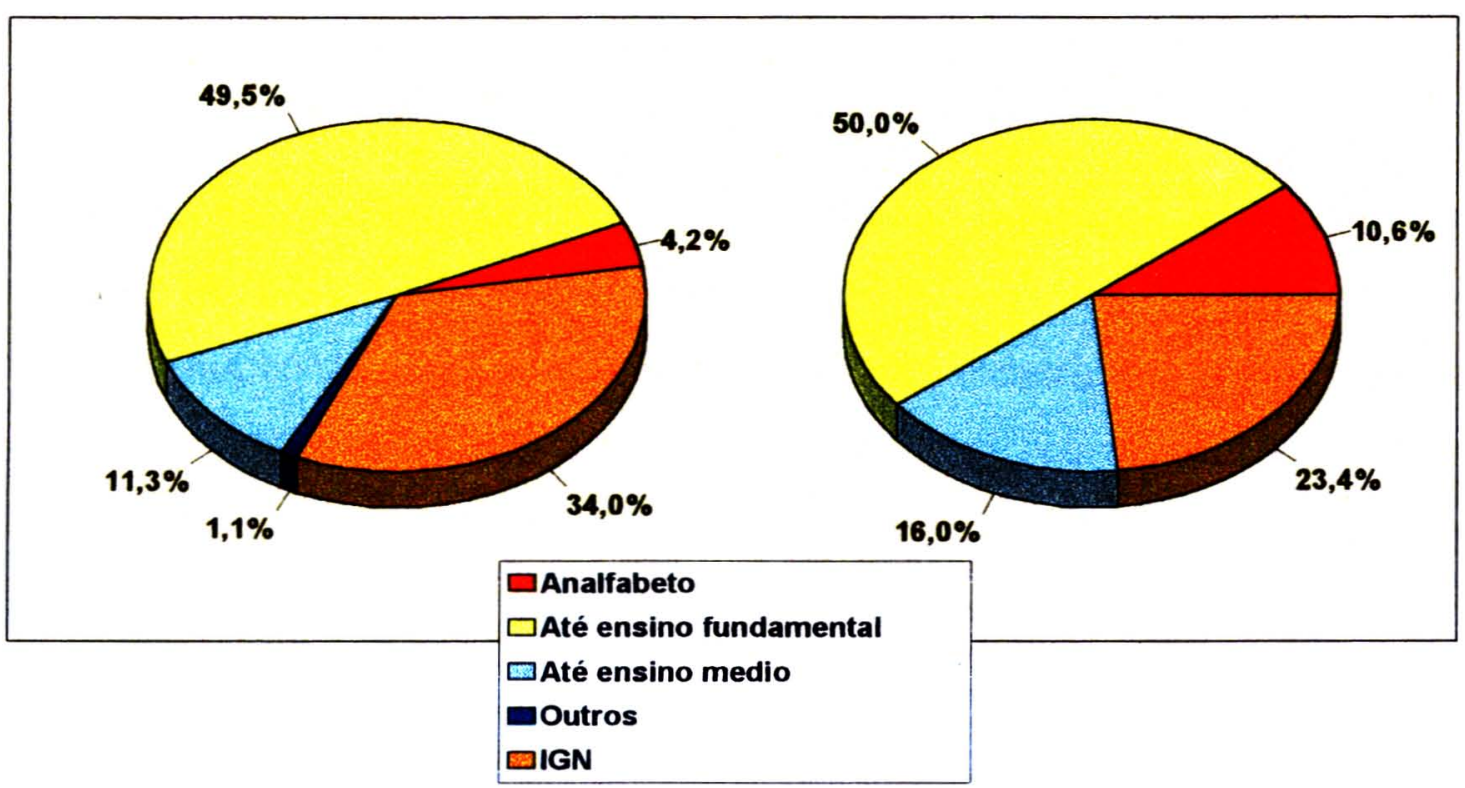

Figura 24: Vitimas e agressores segundo escolaridade. Inquéritos encerrados no DHPP. Municipio de São Paulo, 2000.

O estudo da existência de conflitos com a lei bem como do uso de substâncias psicoativas revelou, para os agressores, percentuais mais desfavoráveis que os encontrados para as vítimas. Em relação à primeira variável, neste grupo sobe para $41,5 \%$ aqueles que possuíam registros nos computadores da polícia civil, sendo que entre esses $29,8 \%$ já tinham cumprido pena e $18,1 \%$ eram reincidentes em homicídios. Em relação ao uso de drogas, esta informação é ignorada para $53,2 \%$ dos casos e $41,5 \%$ declararam-se usuários. Entre estes, não é álcool que ocupa o primeiro lugar, mas sim a maconha (30,6\%), seguindo-se, então, o álcool, com $25 \%$. Em terceiro lugar aparece o uso de drogas múltiplas (exceto álcool), com $22 \%$. Na Figura 25 podem ser vistas as proporções relatadas quanto ao uso de substâncias psicoativas em vítimas e agressores. 
Num estudo com jovens infratores, realizado em Recife e no Rio de Janeiro (Assis \& Souza, 1999) entre as drogas usadas e experimentadas por este grupo, da mesma forma, o álcool não figura em primeiro lugar. No Rio de Janeiro em ordem de freqüência estão a maconha, cocaína e álcool enquanto no Recife estão a maconha, álcool e rohipinol.

O crescimento da circulação de drogas parece ser uma grande preocupação da sociedade. Um levantamento realizado a partir dos telefonemas recebidos pelo serviço de Disque Denúncia ${ }^{11}$, referente ao período de outubro de 1999 a novembro de 2000, mostra que a maior parte das 2.037 denúncias recebidas por este serviço se relaciona ao tráfico e porte de drogas, perfazendo $35,92 \%$ do total. Os homicídios representaram $7,4 \%$.

A relação entre vítima e agressor não foi levantada. Esses resultados são importantes na medida em que apontam algumas lacunas do conhecimento que necessitariam de estudos posteriores.

Vitima

\section{Agressor}

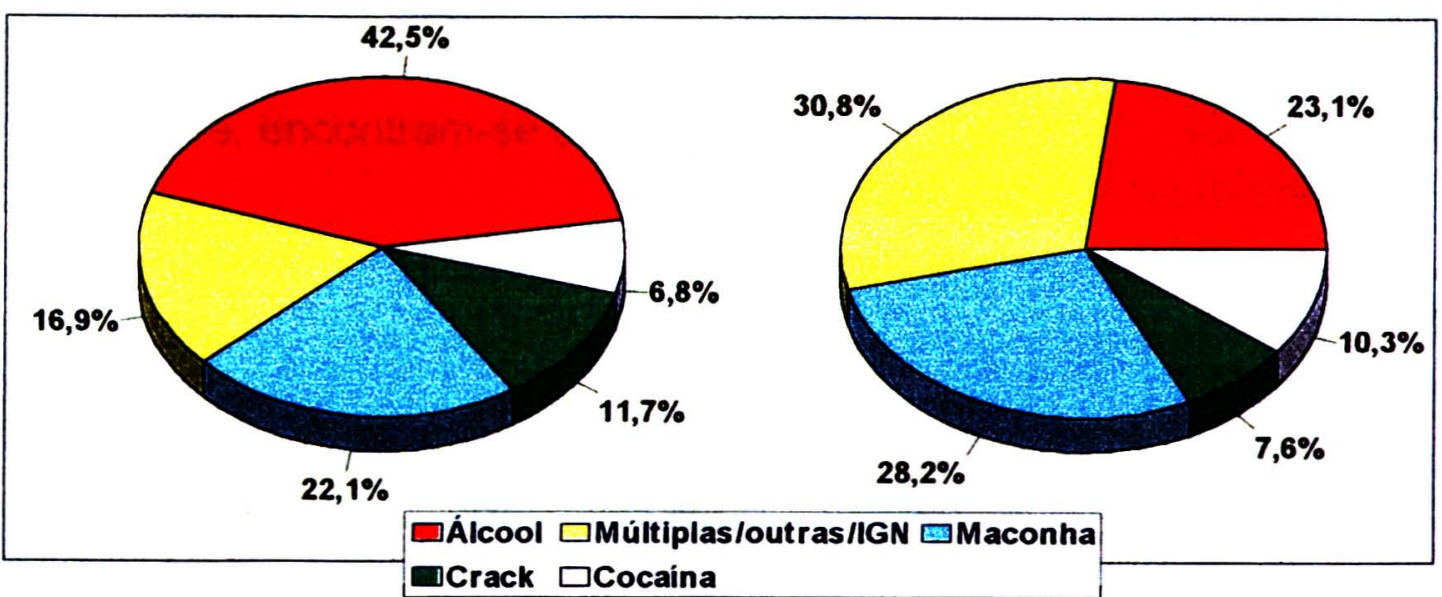

Obs: Excluidos os casos de não usuários e aqueles cuja informação era ignorada

Figura 25: Vítimas e agressores segundo uso de substâncias psicoativas. Inquéritos encerrados no DHPP. Município de S. Paulo, 2000.

\footnotetext{
"Informação pessoal
} 


\subsection{Subsídios do estudo para uma proposta de Vigilancia Epidemiológica dos Homicídios}

Dizer que as causas externas são um grave problema de saúde pública não é uma afirmativa nova. Porém, quando se adota o nome vigilância, isto significa que se quer avançar para além da condução de estudos ou da produção de informações pontuais, ou melhor, que o acompanhamento do agravo e a sua prevenção devem ocupar um lugar nos esforços da saúde pública. Para Hamman (2000), em face das mudanças no perfil epidemiológico dos agravos, tanto em relação às doenças infecciosas (com o surgimento de novos agentes patogênicos), como as nảo infecciosas, faz-se necessária uma revisão e ampliação deste instrumento, uma vez que - sistema rotineiro, organizado nos moldes clássicos, pode não ser suficiente.

O que está proposto neste trabalho é um modelo de um sistema de vigilância que responde às questões básicas: quem? 0 quê? Onde? Quando? Como? Para alcançar esta meta, em se tratando de causas externas, torna-se fundamental integrar informaçōes provindas das várias fontes oficiais, que já realizam registros rotineiros e sistemáticos, os quais, atualmente, encontram-se dispersos.

- Por que integrar dados?

As estatísticas vitais e os registros médicos são adequados para responder quem, qual tipo de lesão e quando a lesão ocorreu, mas são menos úteis para dizer onde aconteceu o evento e especialmente por qué? Isto é particularmente importante para os homicídios. $\mathrm{Na}$ verdade, a 
determinação da causa básica da morte é dependente dos registros policiais, na maioria das vezes.

Sem informaçōes detalhadas sobre as circunstâncias do evento, uma vigilância somente fornecerá os dados constantes na Declaração de Óbito, que, a despeito de serem importantes, sảo reconhecidamente insuficientes para orientar as políticas de prevenção; para isso é necessária a suplementação com outras fontes. Visto que a polícia responde a todo o ferimento por arma de fogo, tendo a responsabilidade legal de determinar o que aconteceu, os registros policiais são o melhor lugar para se obterem dados sobre as circunstâncias, a cena do evento. Da mesma forma, somente no IML é possivel encontrar os dados fidedignos acerca da natureza da lesão, meio utilizado, uso de substâncias psicoativas, entre outros.

\section{- Inquéritos versus vigilâncía epidemiológica.}

Os inquéritos são usualmente um estudo bem definido, delimitado no tempo que podem abranger toda a população ou uma amostra. Por ser um evento pontual, dependendo do desenho e dos objetivos, podem estudar um agravo em profundidade, coletando grande número de variáveis. São ótimos para dar a "linha de base" do problema, mas geralmente náo permitem acompanhar tendências, a náo ser que eles sejam repetidos periodicamente. Os inquéritos, comumente, requerem maiores investimentos de recursos (WHO, 2001). Entre as vantagens neste tipo de estudo encontra-se o fato de permitir maior detalhamento dos dados.

A vigilância é uma atividade contínua $e$, por isso, pode monitorar tendências, detectar variaçōes rápidas e avaliar programas de prevenção. É possivel que, em relação aos homicidios, haja variações rápidas, dependendo das medidas tomadas, como por exemplo, a intensificação de apreensão de armas em determinados locais. Frattaroli e col. (1998) 
afirmaram que a mudança observada na natureza das lesōes em mortes por armas de fogo, em algumas cidades americanas, determinada pela mudança nos tipos de armas utilizadas, somente foi possivel por causa da vigilância implantada.

Uma outra vantagem diz respeito ao maior número de casos que pode ser obtido a partir da vigilância, o que melhora a análise da informação. 0 presente trabalho já apontou prejuizos em algumas análises, por exemplo, segundo os diferentes distritos do Município, devido ao número de casos. Também o seu custo é menor, e espera-se que a partir do momento em que as Instituiçőes envolvidas passem a utilizar os resultados produzidos, elas próprias realizem a coleta e digitação os dados, facilitando a integração.

\section{- Os aspectos operacionais do sistema}

Frente aos resultados que foram obtidos, considera-se que o sistema proposto mostra-se útil para descrever o comportamento epidemiológico das mortes por homicidios, servindo também para avaliar a efetividade das medidas de prevenção. Por isto, pretende-se sintetizar os aspectos operacionais desta vigilância. Conforme Waldman (1998), o desenvolvimento de tais sistemas devem obedecer às seguintes etapas:

- estabelecimento dos propósitos:

É preciso estabelecer os objetivos que se quer alcançar. No caso do Sistema de Vigilancia para Homicídios aqui proposto, estes foram:

- Acompanhar de forma ágil a magnitude do problema e a tendéncia;

- Ampliar o conhecimento sobre as características da vítima e evento, visando a facilitar a identificaçăo dos grupos vulneráveis e a possivel compreensão dos fatores de risco; 
- Oferecer bases técnicas para programas de controle.

- a definição de caso:

A definição do que é caso sempre é uma questão crítica, pois depende dos objetivos do sistema e dos recursos disponíveis (tanto humanos quanto técnicos). Para as doenças infecciosas, geralmente envolve um conjunto de sinais e sintomas e exames laboratoriais.

Para este trabalho os casos são os óbitos classificados como homicidio ou cuja intencionalidade foi indeterminada, em residentes no Municipio de S. Paulo. Para a definição de homicídio pode ser usada aquela que foi apresentada no capítulo da metodologia (OPS, 1996). Ressalta-se que, na área da saúde, a definição de homicídio obedece às regras do CID 10 , enquanto para a segurança pública, não é a mesma, visto que segundo o Código Penal, o crime de latrocínio ou uma agressão seguida de morte não são classificados como homicídios.

- escolha das fontes de dados:

Os sistemas de vigilància para traumas e lesões costumam usar dados de várias fontes (Graitcer, 1992). Além daquelas utilizadas no presente trabalho, também as emergências, internações, serviços de resgate oficiais e outras podem fornecer informações valiosas para o conhecimento do problema.

Um sistema de informações de mortalidade para homicidios, cuja base é a Declaração de Óbito, tem entre suas principais vantagens a relativa facilidade na obtenção destes dados, à sua qualidade, visto que o Ministério da Saúde tem um grupo técnico que discute regularmente estas informaçōes e por último a sua grande representatividade. Porém não apresenta informaçōes acerca do evento. 
A qualidade dos dados constantes nos Boletins de Ocorrência não foi avaliada adequadamente no presente trabalho. O contato com este documento ainda é novo para a área da saúde, além do que suas finalidades não estão ligadas à prevenção nem elaboração de estatísticas. Com o estabelecimento do Info-Crim, a Coordenadoria de Análise e Planejamento destinou alguns técnicos para fazer periodicamente análise de consistência dos BO.

Em relação à coleta de dados em emergências, a sua grande vantagem é permitir o conhecimento da magnitude e das características da morbidade violenta, porém perde em representatividade uma vez que a sua sensibilidade para os casos leves e de média gravidade não costuma ser alta. Entre as desvantagens está o seu elevado custo, ainda que sejam selecionados poucos hospitais sentinelas, visto que seria necessário desenvolver um sistema de coleta de informaçōes específico, treinamento de pessoal, sensibilização das equipes das emergèncias entre outros. Também pode ser apontada entre as vantagens uma melhor descriçăo do evento a partir de entrevistas com a própria vítima ou familiares. No entanto, esta pode estar em estado tão grave que não possa responder ou o medo de represálias ou envolvimentos com a polícia pode tornar algumas das informações prestadas pouco confiáveis (Kellermann, 1998). Devido a isso, Kuo e col. (2000), defendem o uso de múltiplos informantes para pesquisas epidemiológicas acerca da exposiçăo de crianças à violência, para aumentar a confiabilidade e credibilidade dos dados. Um importante passo está sendo dado pelo Ministério da Saúde que pretende implantar um Sistema de Informação em Saúde para Acidentes e Violéncias (SISAV) para os atendimentos realizados nas emergências e ambulatórios, visando o acompanhamento da dimensão do problema (MS, 2002). Considera-se também importante (e com boa acessibilidade) explorar os dados acerca das internações hospitalares a partir do SIH-SUS.

A utilização dos inquéritos policiais como fonte de dados para um sistema de vigilância não se mostrou adequado, pois o tempo decorrido para o seu encerramento pode ser longo. Além disso, acessibilidade/simplicidade săo 
baixas, pois seria preciso visitar cento e dois Distritos Policiais, o que elevaria o custo do sistema. Ainda assim, nem sempre o inquérito que está se buscando encontra-se no local, pois pode estar no Poder Judiciário (Fórum), por vezes só retornando somente em um més ou mais.

\section{- o fluxo de informaçóes:}

A presente pesquisa confirmou que um sistema ativo de coleta de informações cumpre melhor os propósitos de um sistema de vigilância para homicidios. Entre as suas maiores vantagens podem ser apontadas a possibilidade de implantaçăo imediata e sua maior sensibilidade. Uma das desvantagens do sistema passivo é que a captação de casos depende diretamente da adesão dos profissionais na realização da notificação, o que costuma levar um certo tempo. Em se tratando de profissionais de uma outra área que desconhecem o sistema esta tarefa pode ser ainda mais difícil.

Além disso, o papel da notificação é o conhecimento e o registro dos casos. A ocorrência de um homicídio já determina vários registros, todos legalmente obrigatórios, tais como a Declaração de Óbito, o laudo de necropsia, o Boletim de Ocorrência, os inquéritos policiais e os processos judiciais, que podem cumprir este papel. A implantação de mais um instrumento de notificação pode ser duplicação de trabalho e recursos. Por certo, posteriormente, seria importante discutir a viabilidade de adequação, para as finalidades do sistema de vigilância, de alguns destes registros.

Entre as diferentes fontes que foram utilizadas, qual delas seria a base de dados, a partir da qual as informações serão completadas? Sem dúvida deve ser a Declaração de Óbito. Isto se deveu ao fato de ser este o documento oficial que comprova a morte, padronizado, é a base das estatísticas vitais, utilizado em comparaçóes internacionais, sendo um documento único para cada caso (enquanto que é possivel ter mais de um Boletim de Ocorrência 
para a mesma vítima ou também várias vítimas com o mesmo boletim). 0 fluxo proposto é mostrado na Figura 26.

\section{Ocorrencia de um óbito por homicídio} em residente do Município de São Paulo
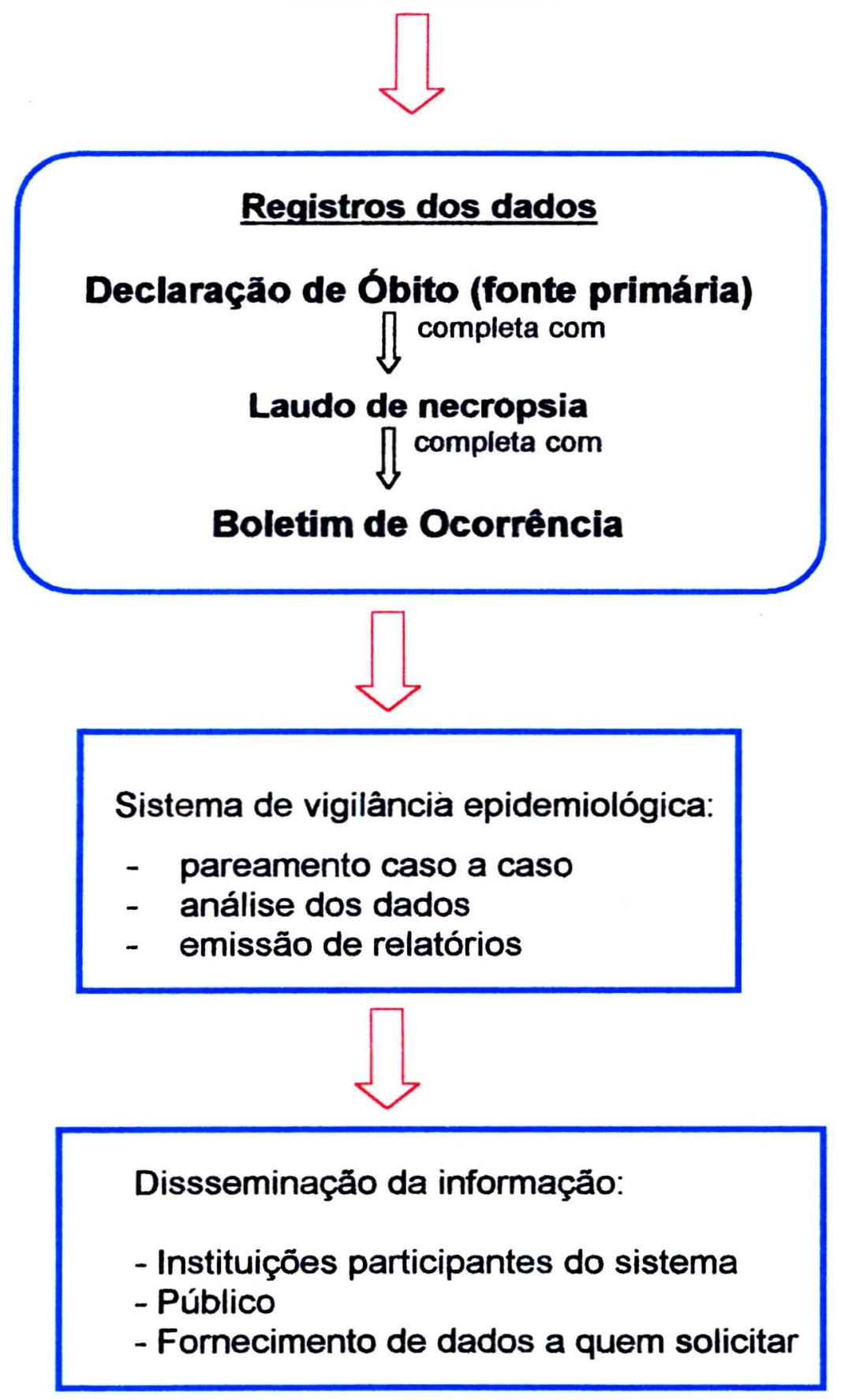

Figura 26: Fluxo de informações para o sistema de vigilância epidemiológica de homicidios. 
A coleta dos dados deve ser mensal, devendo ser respeitado um intervalo de dois a três meses entre o óbito e a coleta de dados, para que a maioria dos laudos de necropsia já tenha sido encaminhada para o IML central; o PRO-AIM, já possa ter revisado as causas de morte e todos os boletins já tenham sido digitados no sistema. Por isso, estima-se que a divulgação dos dados pode se dar após quatro meses do evento. Esse tempo deve ser diminuido a partir do aprimoramento do sistema.

- As varíaveis selecionadas segundo as díferentes fontes de dados

Como algumas das variáveis levantadas podem ser encontradas em várias fontes, após uma comparação entre elas, são apresentadas a seguir em que fonte as variáveis selecionadas devem ser coletadas (assinaladas com "X"). Este resultado confirma a idéia inicial do estudo, que em algumas fontes as informações têm maior qualidade que em outras.

Considera-se que a causa básica de morte deve ser buscada nas três fontes, com a finalidade de corrigir eventuais erros de classificação $\theta$ esclarecer os casos cuja intencionalidade foi ignorada. No caso de verificar se houve possibilidade de assistência médica à vítima, propōe-se a consulta às duas fontes onde esta informação encontra-se disponivel. $\mathrm{Na}$ verdade, este dado apresentou baixa qualidade mas como é de grande importáncia para área da saúde, ele deve ser analisado com reservas enquanto se tenta o seu aprimoramento. 


\begin{tabular}{|l|c|c|c|}
\hline \multirow{2}{*}{ Variável } & \multicolumn{3}{|c|}{ Fonte } \\
\hline Identificador & $\mathbf{X}$ & $\mathbf{X}$ & $\mathbf{X}$ \\
\hline Idade & $\mathbf{X}$ & & \\
\hline Sexo & $\mathbf{X}$ & & \\
\hline Estado civil & $\mathbf{X}$ & & \\
\hline Local de Residência & $\mathbf{X}$ & & \\
\hline Meio utilizado & & & $\mathbf{X}$ \\
\hline Natureza da lesão & & & $\mathbf{X}$ \\
\hline Causa básica de morte & $\mathbf{X}$ & $\mathbf{X}$ & $\mathbf{X}$ \\
\hline Uso de substâncias psicoativas & & & $\mathbf{X}$ \\
\hline Local de Ocorrência & & $\mathbf{X}$ & \\
\hline Dia da semana da ocorrência & & $\mathbf{X}$ & \\
\hline Horário da ocorrência & & $\mathbf{X}$ & \\
\hline Tipo de local & & $\mathbf{X}$ & \\
\hline Assistência médica & & $\mathbf{X}$ & $\mathbf{X}$ \\
\hline Motivo & & $\mathbf{X}$ & \\
\hline
\end{tabular}

- Avalíação do sistema:

Segundo Waldman (1998), o desenvolvimento de sistemas de vigiláncia requer revisões e modificações periódicas, baseadas em critérios de utilidade, custo e qualidade. Alguns atributos devem ser avaliados:

Simplicidade: O estabelecimento deste sistema é importante e necessário, seguindo o modelo que atualmente é proposto em outras partes do mundo (WHO, 2001; Ikeda e col, 1998), porém a sua implementação não é tarefa simples.

As dificuldades não se encontram ligadas ao número de fontes, mas às características do evento em queståo. Um homicidio é um crime e 
portanto o acesso aos dados costuma ser dificil, o que também ocorre em outros locais fora do Brasil (Kellerman e col, 1998). Além disso, com o avanço da percepção da violência por parte da sociedade brasileira, a área da Segurança Pública encontra-se muito pressionada pela mídia.

A grande facilidade fica por conta da boa acessibilidade/simplicidade dos dados de estatística vital, visto que o PRO-AIM, no Município de Sáo Paulo, já digita todos os campos constantes da Declaração de Óbito e pode disponibilizá-las através de meio magnético ou via e-mail. Em se tratando de municípios do interior do Estado, também a Fundação SEADE disponibiliza os dados para a Secretaria de Estado de São Paulo, cerca de três meses após o término do trimestre.

As Delegacias Policiais são em número de cento e duas no Município de São Paulo, mas a Secretaria de Segurança Pública possui, um sistema informatizado (InfoCrim), em que os Boletins de Ocorrência são digitados via on-line, podendo ser consultados em um único lugar centralizado. Por certo, uma parte dos homicídios é encaminhada ao DHPP, determinando que a pesquisa aos $\mathrm{BO}$ seja feita em dois locais diferentes.

O IML possui três agências: centro, sul e leste. Porém, depois de um determinado periodo, todos os laudos são encaminhados para serem arquivados no IML central. Embora o número de mortes seja expressivo (consituindo-se, por isso, em uma das dificuldades do sistema), não são muitos os lugares onde esses óbitos serão pesquisados.

Utilidade: segundo Waldman (1998), este atributo expressa, em resumo, se - sistema consegue alcançar seus objetivos. É possível verificar que a integração de dados ampliou o número de variáveis estudadas, agregando qualidade aos dados.

Aceitabilidade: reflete o desejo de individuos e organizações em participar no sistema de vigiláncia. 
A principio, considera-se que as Instituições envolvidas estão sensibilizadas para a necessidade de ampliar o conhecimento do problema. As perspectivas säo promissoras, pois a própria Secretaria de Segurança Pública tem interesse em compatibilizar essas informações, tendo formado um grupo inter-setorial para trabalhar esta questão, contando com a participação da Secretaria de Estado da Saúde, Fundação SEADE e PROAIM.

Confiabilidade: os dados gerados pelo sistema devem ser confiáveis para que possam ser utilizados.

Neste aspecto a avaliação é muito boa. Certamente é impossivel que um sistema conheça cem por cento dos casos. No entanto, usualmente, as mortes por causas externas são conhecidas em sua maioria, especialmente as intencionais, visto que são crimes. Entende-se, então, que tal sistema une sensibilidade (a capacidade do sistema de detectar casos) e especificidade (a habilidade para incluir somente os que forem realmente casos) altas. Da mesma forma, possui alta cobertura e representatividade (cobre a maior parte dos eventos).

Especificamente em relaçāo aos homicidios, o que pode escapar do sistema seria a existência de cemitérios clandestinos e os casos de mortes cuja intencionalidade foi ignorada, mas que uma melhor investigação poderia identificar um homicidio. No Municipio de São Paulo, esta categoria respondeu por apenas $3,6 \%$ do total de causas externas no ano de 2000 . Um outro problema identificado diz respeito aos óbitos de residentes no Municipio de S. Paulo, mas cujo sepultamento ocorre em outro município. Visto que até o ano de 2000, o PRO-AIM tinha acesso somente às Declarações que eram registradas no Serviço Funerário Municipal, esses óbitos nāo eram incluidos no sistema. A partir de 2001, tal fato não deve mais ocorrer. De qualquer modo, aqueles podem ser recuperados a partir dos dados da Fundação SEADE. 
Flexibilidade: o sistema pode acomodar mudanças nas variáveis tanto no decorrer do processo, se novas necessidades surgirem, ou após a divulgação dos primeiros resultados. Pode também incorporar dados de morbidade.

- O pareamento dos casos:

O identificador para o pareamento caso a caso é o nome. Para alguns óbitos, é necessário utilizar também a data de óbito, idade e sexo. $\mathrm{Na}$ integração das Declaraçōes de Óbito com os dados dos laudos de necropsia, o pareamento tem que ser manual (o que costuma ser demorado), visto que os laudos não são digitados. Já com os Boletins de Ocorrência, o pareamento não precisa, necessariamente, ser manual. Para isso, é preciso buscar um campo numérico, comum aos bancos, para fazer esta ligaçăo. 0 número do Boletim de Ocorréncia e Delegacia de Polícia seria o mais adequado, pois não se repete. O IML tem plenas condições de transcrever na Declaraçăo de Óbito estes números, permitindo que um menor número de casos restasse para a integração manual.

Serão apresentados a seguir os percentuais somente do pareamento inicial, sem a busca refinada (e também demorada) que foi realizada posteriormente. O banco do PRO-AIM, continha 1387 Declarações de Óbito, referentes aos homicídios ocorridos nos meses de abril a junho de 2000 e o banco do Info-Crim continha 1463 Boletins de Ocorrência de óbitos por homicídios ocorridos no mesmo período. Foram eliminados $126 \mathrm{BO}$ durante a pesquisa, pois descobriu-se que ou não eram homicidios ou tratava-se de boletins complementares (mais de um boletim para uma mesma vitima).

Inicialmente, foram ligados 962 casos $(69,4 \%)$. Na Delegacia de Homicídios e Proteção à Pessoa, foram encontrados 170 casos que não constavam do Info-Crim, o que fez subir o número de casos pareados para $1132(81,6 \%)$. No banco-base, havia 77 desconhecidos, onde no campo 
"nome" consta o número do laudo de necropsia. Após a pesquisa no IML, foram levantados os 50 BO correspondentes, o que eleva o percentual de casos pareados para $85,2 \%$. Dependendo dos recursos disponiveis para o sistema de vigiláncia, é possível que somente este primeiro pareamento possa ser realizado. Considera-se que este percentual é satisfatório para proceder aos cruzamentos das variáveis, lembrando que cada um desses bancos também permite análises em separado.

É preciso estar atento às diferenças de classificaçăo entre o Código Penal e o CID 10, na ocasião da solicitação do banco de dados à Secretaria de Segurança Pública, para garantir que todas as vítimas sejam incluídas nesse banco.

O cruzamento dos dados das Dos com os laudos de necropsia apresenta percentuais maiores, pois apenas 36 laudos não foram encontrados no primeiro levantamento $(2,6 \%)$. Por esta razão, sugere-se que a primeira integração seja realizada DO versus laudo de necropsia.

\section{- Outras experiências de Vigílancia}

Os Estados Unidos têm sistemas de vigilância para prevenção de lesões por arma de fogo (Rosenberg \& Hammond, 1998) implantados em sete estados. Estes foram propostos em razão de algumas deficiências do Sistema Nacional de Estatística Vital, daquele país, que trazem dificuldades para o monitoramento adequado deste agravo. Entre elas, cita-se o tempo de liberação dos dados de mortalidade (que leva dois anos) e a ausência de informaçōes acerca das circunstâncias do evento, como relação entre a vítima e o autor, local de ocorrência e uso de substâncias psicoativas, entre outras (Mercy e col., 1998). Os pontos comuns entre esses sistemas de vigilância são a integração de fontes de registros selecionadas e por possuírem sistemas de avaliação. 
A vigilância na Califórnia, por exemplo, onde algumas regiōes apresentam a mortalidade por armas de fogo em niveis mais altos que os acidentes de trânsito (Kim e col. 1998), enfatiza o trabalho com as populações de risco. Suas fontes são as declaraçōes de óbito, arquivo de homicídios (do sistema penal) e registros de altas hospitalares. Os resultados desta vigilancia (a partir de 1994), mostram que, $56,7 \%$ destas mortes foram devidas aos homicidios, $38,4 \%$ foram suicídios e $2,6 \%$ foram intencionais.

Na cidade de Nova York, o sistema de vigilância foi iniciado em 1993, é um sistema ativo, que acompanha a morbimortalidade das lesões decorrentes de agressões, utilizando múltiplas fontes. Constituem as fontes primárias os seguintes registros: estatísticas vitais para as mortes, arquivos das altas hospitalares para as hospitalizaçōes e dados provenientes das emergências hospitalares ( 11 hospitais participantes, que atendem $50 \%$ da demanda de toda a cidade, servindo ás áreas mais pobres, que apresentam as maiores taxas para lesões por violências). As fontes consideradas suplementares são os registros policiais (especialmente com a finalidade de estabelecer o motivo da agressão e grau de relação entre a vítima e o agressor), laudos de balística e prontuários médicos. Eles não integram esses dados caso a caso, por considerar que isto elevaria o custo do sistema, mas garantem que cada caso seja contado somente uma vez. As variáveis coletadas são: dados demográficos do paciente (idade, sexo, raça, etnia, endereço de residência, localidade de residência), da lesão ou morte (tipo de arma, localizaçăo da lesão, severidade), circunstâncias (fatores precipitantes da agressão, relação vítima-agressor, local do incidente, agressão ou auto-inflingido), fatores temporais (mès do incidente, dia e hora do incidente) $e$ indicadores econômicos (origem do pagamento o cuidado médico). Os resultados mostraram que a mortalidade por agressões caiu $46 \%$ entre 1990 e 1995 , de 27,5 para $14,7 / 100.000$; o decréscimo foi mais expressivo entre os homens, e a taxa de hospitalização decresceu de 311,4 para 190,5/100.000, após a implantação do modelo (Wilt e Gabrel, 1998). 
O tema é tão atual que dos sete projetos que constavam da página da Internet, do National Center for Injury Prevention and Control da Universidade de Harvard (2001), Boston, (EUA), seis deles vêm buscando criar sistemas que juntem informações oriundas dos serviços de saúde com registros policiais e outros serviços.

\subsection{Fatores associados e estratégias de intervençăo}

Conforme Minayo \& Souza (1999), "Para aplicação do conceito de prevenção, no caso da violência é importante saber quais são as questóes que estão em pauta para determinada sociedade, os grupos prioritários para atuação e quais seriam as melhores estratégias de atuação". Desse modo, esta última parte do trabalho pretende abordar dois aspectos. O primeiro deles é discutir alguns dos fatores associados à mortalidade por homicídios, que vêm sendo apontados pela literatura. Cabe assinalar que não se espera esgotar $o$ assunto $e$, por certo, algumas abordagens importantes deixarão de ser feitas. Pretende-se apenas agregar questões que possam contribuir para uma melhor interpretação e utilização dos dados oficiais, que são os analisados neste trabalho. O segundo aspecto, é buscar descrever alguns conceitos e experiências que vêm sendo realizadas na área de prevenção, esperando contribuir com técnicos que queiram trabalhar na área.

Como já citado anteriormente, a literatura é vasta em relação aos diferenciais na mortalidade violenta e de saúde como reflexo das desigualdades de uma sociedade. No entanto, isso não explica porque, como chamou atenção Zaluar e col. (1994), o Piauí, um dos estados mais pobres da nação não exiba altas taxas de mortalidade violenta.

Também Szwarcwald e col. (1999) chamam a atenção para o fato de que algumas sociedades desfrutam de condiçōes de saúde bem melhores do 
que as esperadas para os seus níveis de renda e vice-versa, sugerindo que outros fatores relacionados à complexidade da estrutura social podem influenciar mais profundamente a situação de saúde do que os índices de pobreza. O problema não seria a situação de pobreza em si, mas a convivência com desigualdades profundas, a chamada pobreza relativa, aquela que exclui pessoas, social e materialmente, das oportunidades proporcionadas pela sociedade. Os autores referem que vários trabalhos demonstraram, de forma consistente, a existência de melhores condiçōes de saúde em sociedades com distribuição de renda mais equilibrada. Por isso, estudaram a correlação entre desigualdade de renda e alguns indicadores de saúde. Todos eles mostraram correlação significativa, sendo que as maiores correlaçōes foram observadas para a taxa de homicídios e, depois, a esperança de vida ao nascer.

Por isso, compreendem que a questão da violência urbana entre os jovens não pode ser dissociada da aguda disparidade presente em sociedades como a nossa, que pouco investem em programas sociais, de educação e assistência médica pública, habitação e capacitação profissional adequada. Isso aumenta a frustração e o estresse, fomentando rupturas sociais e familiares, levando ao aumento da criminalidade e ao uso de álcool e drogas. Introduz-se aí um outro conceito, que é o da coesão social, apontando que estas sociedades tendem a ser menos coesas (Szwarcowald e col, 1999)

É sabido que o Brasil é um pais que apresenta um dos níveis mais elevados de concentração de renda no mundo. O relatório da Naçóes Unidas de 2001 coloca o pais no $69^{\circ}$ posto do índice de Desenvolvimento Humano, atrás de paises como a Colómbia, Venezuela e Trinidad Tobago, cuja renda per capita é muito menor que a brasileira. Entre os indicadores de desigualdade mais utilizados está a razão entre a renda dos $10 \%$ mais ricos em relação aos $40 \%$ mais pobres. Para grande parte dos paises este indicador tem valores inferiores a 10 (Szwarcwald e col. 1999). O Brasil, segundo última Pesquisa Nacional por Amostra de Domicilios, de 1999 
(IBGE, 2001) apresentou o valor deste indicador em 22,1. Esta razão para a região Metropolitana de São Paulo é 18,2.

Por outro lado, há que se registrar que não há explicação que contemple todos os aspectos da questão, visto que alguns Estados como a Paraíba (razão de 31,1 ), Distrito Federal $(30,4)$ e Bahia $(20,3)$, apresentam esta relação entre as mais altas do país $\theta$, ao mesmo tempo, não se encontrem entre as maiores taxas de homicídios no Brasil (Mello Jorge e col. 1997).

Para Rolnik (1999), mesmo a pobreza, a desigualdade e até as transformaçōes no mercado de trabalho podem ser tratadas de formas diferentes por comunidades $e$ indivíduos dependendo do grau de coesão social e vulnerabilidade. Com certeza, a exclusão contribui de forma importante para tornar individuos, famílias e comunidades particularmente vulneráveis, abrindo espaço à violência e ao conflito.

Um outro lado desta questão, com a qual é preciso tomar cuidado, é que esta associaçăo pobreza/violéncia/adolescência pode levar à estigmatização e à conseqüente discriminação. $E$ isto pode produzir danos profundos para a imagem do jovem pobre. No Rio de Janeiro, na década de 80 (a exemplo do que hoje ocorre com o Jardim Ângela na cidade de São Paulo, mas em menor intensidade), o bairro da Cidade de Deus, na zona oeste da cidade, ocupava a midia como um lugar de grande criminalidade, o que de fato era verdade. Isso determinou grande discriminaçăo e, Zaluar (1994) relata que algumas pessoas dessa comunidade se viam obrigadas a esconder seus endereços ao preencher ficha para postos de trabalho, para não serem identificados como possiveis criminosos. 0 mesmo, por vezes, ocorria em relação, por exemplo, a novos amigos e namorados.

Especificamente em relação ao grupo de adolescentes e jovens, nunca foi tão urgente conhecer as questões da juventude, seus desejos e impasses. Uma das características mais marcantes da sociedade atual é a velocidade e a intensidade das transformações da vida, o que faz emergir a incerteza sobre os próprios destinos. Nunca o futuro pareceu tão 
imprevisivel, nunca se percebeu tão claramente que os projetos de vida podem náo acontecer como foram planejados, devendo ser adaptados continuamente. Esta percepção faz com que o jovem se sinta muito vulnerável.

Por outro lado, em função de um comportamento natural e legítimo, presente como nunca nos tempos atuais, o jovem quer a possibilidade de consumir os símbolos da juventude (a roupa da moda, o tênis de marca, freqüentar danceterias, ter CDs e aparelhos de som), os marcos da juventude do seu tempo. Isso pode se dar pela mesada para os setores médios ou o emprego para os setores populares. É preciso buscar alguma fonte de renda.

No entanto, o jovem brasileiro encontra neste momento um cenário de enxugamento dos postos de trabalho no mesmo momento em que faz parte de uma onda demográfica que pressiona esse mercado. Com o desenvolvimento tecnológico, os empregos se tornam cada vez mais restritivos e seletivos. Embora seja inegável que aumentou o acesso à educação, permanece a inadequação dessa educação que thes é oferecida diante das exigências do mundo atual.

Um fenômeno já amplamente reconhecido como a exclusão juvenil, observado em quase todos os paises da América Latina, é que as taxas de desemprego nessa faixa duplicam e até triplicam a dos adultos. Isto cria um círculo vicioso, porque se não se tem rendimento próprio, não é possível planejar o futuro. É neste cenário, propício para a erosão da auto-estima e da esperança, onde o jovem morador de localidades já conturbadas encontra a violéncia e esta, terreno para se instalar e crescer.

Sob esse aspecto é importante considerar o papel indiscutivel da televisão para acirrar a seduçăo de consumo entre os jovens. Esse grande mercado consumidor, não passa despercebido pela mídia, sendo isto um fenómeno internacional ${ }^{12}$. As pressőes e a sensibilidade para o consumo

\footnotetext{
${ }^{12}$ Atualmente na TV brasileira existem programas voltados para o público adolescente e suas questöes, como é o caso da série Malhação, da TV Globo. Na TV americana, este fenômeno é mais antigo e o número de programas oferecidos é maior.
} 
nesse mercado são fatos conhecidos e disseminados no mundo e a midia tenta caracterizar uma série de símbolos representando o que é ser jovem.

No Brasil, esse fenômeno se intensifica, dada a disseminaçăo que a televisão vem alcançando, especialmente nos anos 90, com enorme crescimento nos espectadores das classes C e D. Segundos dados de Madeira (1999), entre 1994 e 1998, graças ao controle da inflação e estabilização econômica, foram vendidos cerca de 28 milhões de aparelhos, quase dobrando a base instalada na primeira metade da década. Calculase que seis milhōes de famílias adquiriram seu primeiro aparelho de televisão, todas elas localizadas na base da pirămide social. A televisão, que sempre atuou como inspiradora para o consumo em geral, chega a uma parcela maior de consumidores. E o sonho de felicidade que é vendido passa necessariamente pela aquisição de bens e valores do consumo.

Cabe lembrar que a associação entre adolescência e criminalidade não é inquietaçăo somente de sociedades com acentuadas desigualdades sociais. Diante das circunstâncias que envolveram os episódios escolares norte-americanos (cabendo citar o chocante episódio ocorrido na Columbine High School, numa pequena comunidade do Colorado, no ano de 2000), é difícil acreditar que apenas diferenças sociais, niveis de pobreza ou quaisquer outras explicações exclusivamente socioeconômicas sejam suficientes para explicar as manifestações de violéncia por parte da juventude. E o mesmo acontece na desenvolvida Europa, quando algumas Prefeituras da França, numa polêmica medida, estão proibindo os menores de seis a treze anos de andarem pelas ruas, em determinados horários noturnos ${ }^{13}$. Este "toque de recolher" visa reduzir a violéncia, tem limite de duração até o final do verão de 2001 e também limite geográfico, sendo restrito aos quarteiröes mais pobres, considerados de alto risco.

Os jovens serão, de fato, promotores da violéncia ou são sobretudo vitimas? A literatura internacional aponta um crescente envolvimento dos adolescentes no mundo do crime violento. Do mesmo modo, igualmente se

\footnotetext{
${ }^{13}$ Jornal Folha de São Paulo, 18/07/2001.
} 
aponta a crescente vitimização desses jovens. Adorno (1999) ao comparar os padrōes de criminalidade na população em geral e entre os adolescentes, nos periodos compreendidos entre 1988-1991 e 1993-1996, conclui que houve um crescimento efetivo da criminalidade juvenil, em especial a do tipo violento, verificando inclusive que, no último periodo, o percentual de infraçōes violentas cometidas por adolescentes supera ao correspondente da população em geral. E chama a atenção para o fato de que tal fenômeno afeta igualmente outras sociedades mais desenvolvidas, como a França e a Inglaterra. Este mesmo autor também refere que não é somente a crise econômica que deve ter contribuído para isso, mas também o crescimento do crime organizado nas áreas urbanas, que vem ocorrendo há cerca de duas décadas. Para isso, mostra que a participação de jovens em bandos e quadrilhas é um padrão emergente, pois não era verificado no período 198891, mas somente no de 1993-96.

Ao mesmo tempo não se deve super dimensionar esta questão. Madeira (1999) aponta uma pesquisa da Unesco, realizada no Distrito Federal, sobre a formação de gangues de adolescentes na qual, 10,7\% revelaram ter tido experiências de participaçăo em gangues, mas apenas $1,1 \%$ declararam pertencer, naquele momento, a uma delas. A maioria está concentrada na faixa de 15 a 17 anos. A partir dessas informaçōes pode-se concluir que o número de jovens é realmente pequeno, menor do que o nosso imaginário pode supor. Além disso, trata-se de um fenômeno transitório, geralmente superável. O problema está associado à existência de tempo livre, pois $38,3 \%$ estudam mas não trabalham e $27 \%$ nem estudam e nem trabalham, $18,5 \%$ trabalham e $16 \%$ combinam estudo e trabalho. De acordo com o modo de atuação, esses jovens podiam ser divididos em dois grandes grupos: aqueles que praticam pequenos roubos e consomem drogas e aqueles que se associam com traficantes e assaltantes. $O$ estudo também apontou um outro dado importante: maior consumo de álcool e drogas entre os membros destas gangues, pois $81,5 \%$ fazem uso de álcool, caindo para $55 \%$ entre aqueles que não estão envolvidos. O uso de maconha é de $16 \%$ e $2 \%$ e, no caso da cocaína $7,5 \%$ e $1,5 \%$, respectivamente. 
Uma das contribuições fundamentais que pode ser dada pela área da saúde, utilizando especialmente o instrumental epidemiológico, deve ser no sentido de identificar as situaçōes sociais de risco.

Uma outra importante (e antiga) discussão diz respeito ao conceito de acidentes. A saúde pública, no Brasil e no nivel internacional, lutou para que eles não fossem encarados como eventos frutos do azar, afirmando e reafirmando que são passíveis de prevenção. Conforme Minayo \& Souza (1999), "a prevenção da violência impōe dois grandes esforços adicionais: o de superar a noção de "fatalidade" e de "inevitabilidade" que envolve o senso comum da visão sobre o problema".

Também as violências devem ser consideradas como eventos que podem ser previsiveis, podendo existir, portanto, oportunidades de intervenção. Por exemplo, os casos de crimes violentos contra a mulher são geralmente cometidos por pessoas conhecidas, do seu próprio meio de relacionamento (Lima 2000), sendo que, em muitos casos, precedidos de ameaças e brigas. Esta mulher pode ter procurado o serviço de saúde, emergência ou mesmo uma delegacia de polícia; a familia sabe do comportamento violento, os vizinhos já viram e ouviram discussões. O mesmo pode ser dito a respeito dos maus tratos às crianças.

A área da saúde precisa modificar seu olhar sobre este problema. Minayo \& Souza (1999) citam que o inicio da mudança de visão do setor saúde sobre a violência, não mais como um mero reparador dos estragos provocados ou um contador de eventos, se deu a partir da década de 60, quando "a pediatria americana passa a estudar, diagnosticar e medicar a sindrome do bebé espancado ${ }^{14}$, colocando-a como um sério problema para o crescimento e desenvolvimento infantir". Tornando público e passível de intervençăo, o que antes era considerado de foro privado.

Várias pesquisas, principalmente entre os norte-americanos, vêm sendo realizadas para apontar fatores de risco que possam predizer 
comportamentos violentos (Farrington e col., 2000). Alguns deles são individuais (alta impulsividade), outros dizem respeito à familia (pobreza, pais violentos, alcoolismo, má supervisão), viver num bairro violento, pertencer a gangues, baixo aproveitamento escolar, utilização de álcool e drogas precocemente.

E por acreditar firmemente que a promoção da saúde é um antigo compromisso da saúde pública, considera-se, então, que é preciso planejar açōes com foco no nivel de prevenção primário. E para as violências, isso deve se dar de um modo diferente do que vem sendo realizado para os outros agravos, podendo ser, inclusive, único para cada realidade particular. Embora pareça uma tarefa difícil, compreender que a violência do jovem e contra o jovem tem, freqüentemente, raizes num conjunto de condiçōes sociais adversas, que são identificáveis e potencialmente modificáveis é, na verdade oferecer uma mensagem otimista à sociedade (Currie, 2000).

\section{- Fatores de risco identificados em nosso meio}

São poucos os trabalhos, realizados no Brasil, com a finalidade de identificar fatores de risco para homicídios ou comportamento infracional.

Assis e Souza (1999) compararam jovens infratores e não infratores pertencentes à mesma família, em duas cidades, Rio de Janeiro e Recife. As autoras referem que aquelas famílias viviam em extremo grau de fragilidade, situação de pobreza e exclusão social. Vivenciavam problemas na esfera afetiva e econômica, devido à auséncia da figura paterna no lar (a maior parte era de casais separados) e também da mãe, visto que esta trabalhava fora e tinha poucos recursos para cuidar das crianças. Além de experimentar relacionamentos marcados por agressões, esses jovens também eram

\footnotetext{
${ }^{14}$ Esses agravos, com essa denominação, já foram englobados na 9". Revisão da Classificaçăo Internacional de Doenças (OMS, 1980), em 1975. Na 10". Revisão (OMS, 1996), aparecem como "Maus Tratos na Infância".
} 
expostos à violência na comunidade em que viviam. A situação de pobreza foi evidenciada ao ser verificado que $90 \%$ deles já haviam atuado no mercado de trabalho, sendo que $20 \%$ tinham iniciado o trabalho entre sete e nove anos. A idade média dos infratores foi de 16 anos. Possuiam baixa escolaridade, com cerca da metade dos entrevistados, tendo freqüentado até no máximo, a $4^{\circ}$ série do ensino fundamental e nenhum chegou ao ensino médio. $O$ grupo de amigos desses jovens pertence ao mundo do crime. Consomem drogas, com início do uso por volta de 13 anos. Revelaram uma maior necessidade de consumo se comparados com os não infratores. Observou-se falta de controle familiar neste grupo, muitos deles são caçulas e se consideravam os preferidos da familia.

Em relação aos jovens não infratores, embora pertencessem ao mesmo grupo social, o perfil encontrado foi um pouco diferente. Preferem amigos fora do universo da criminalidade, não utilizam drogas rotineiramente, almejam ir mais longe profissionalmente e revelam um planejamento mais ambicioso para o seu próprio futuro. Apresentam maior capacidade de lidar com as perdas familiares e estabelecer vínculos afetivos mais fortes.

Falbo e col. (2001) realizaram trabalho em Recife, desenhado para identificar fatores potencialmente modificáveis (estudo caso-controle). 0 grupo caso foi representado por vítimas de homicidios com idade menor de 20 anos e o controle foram vizinhos, pareados por sexo e idade. Os fatores de risco encontrados, foram histórico de registros policiais anteriores e uso de drogas ilicitas, entre outros. Entre os fatores protetores identificados encontra-se maior nível educacional e a existência de práticas religiosas.

\section{- Algumas experiências de intervenção}

Entre os caminhos que vêm sendo tentados para minimizar a questão, existe um grande número de iniciativas oriundas da própria comunidade, 
com o sentido de reduzir a violència, em sua maioria de pequeno porte, que vão desde grupos de música, artes, capoeira até associações para a promoção da paz.

Referindo-se especificamente à área da saúde, o volume dessas iniciativas já se reduz, estando relacionado com a criação de ambulatórios de álcool e drogas em algumas comunidades.

No Brasil, o estudo e o estabelecimento de estratégias de prevenção não vem tendo prioridade, enquanto política pública. Aliado a isso, um dos prejuizos dessa constrangedora desigualdade econômica e social, na qual vive a sociedade brasileira, é um certo descrédito de intervenções que não estăo concentradas na raiz do problema. Por certo, uma melhor redistribuição de renda e crescimento econômico têm impacto positivo sobre a violència, independentemente de qualquer outra ação. Mas esta é uma tarefa que pertence ao conjunto da sociedade. Problemas especificos requerem políticas especificas, ainda que eles estejam fortemente correlacionados à questões muito maiores, como é o caso dos homicídios.

Neste aspecto, cabe lembrar o sociólogo Herbert de Souza, que fez uma campanha, mobilizando o pais, para acabar com a fome, a necessidade mais básica de todas. Sem dúvida, a fome é a expressão máxima e a face mais cruel da má distribuição de renda. No entanto, a sociedade póde minimizar este problema, independentemente da adoção de outras políticas. Por isso, considera-se fundamental relatar algumas experiências, ou apontar alguns caminhos que sejam possíveis, que possam ser aproveitados e adaptados.

É evidente que as experiências de intervenção implementadas a partir de um conhecimento cientifico do problema podem ter maiores chances de sucesso. Por isso, o National Center for Injury Prevention and Control do Centers for Desease Control and Prevention (CDC) (Powell e col. 1996) acompanha projetos, alocados em diferentes cidades dos Estados Unidos, desenhados com o objetivo de reduzir a freqüência e a gravidade da violência interpessoal entre os jovens. Todas as intervençōes foram 
baseadas em modelos elaborados a partir de pesquisas científicas anteriores. A maior parte desses projetos, envolve a escola, trabalhando com a promoção da saúde.

Alguns focalizam os estudantes que freqüentam o elementary school (o que corresponderia aos primeiros anos do ensino fundamental brasileiro), tem como proposta de trabalho ensinar um melhor manejo da raiva, resolução de problemas e outros processos cognitivos. Os projetos que envolvem alunos um pouco maiores (nas middle schools), vão mais além, já trabalhando atitudes e habilidades, para reduzir seu envolvimento com a violência, promovendo alternativas pacificas e positivas para lidar com ela. Os estudantes são encorajados a resolver um problema de conflito interpessoal, avaliando as informações, considerando as conseqüências, tomando decisões e avaliando as respostas (Farrell 1996). Très desses projetos têm como público alvo jovens mais velhos, envolvendo ajuda para a superação de baixo rendimento escolar e oportunidade de emprego, visando, não somente desenvolver habilidades, mas também a esperança de um futuro mais produtivo.

O projeto desenvolvido na Carolina do Norte envolve jovens do sexo masculino, com idades entre 12 e 16 anos, afro-americanos. Esta população, segundo os autores (Ringwalt e col., 1996), sofreu dramático aumento na morbimortalidade por causas violentas. A intervenção é baseada em alguns fatores de risco identificados - ausência de educação dos pais, famílias chefiadas pela mãe, localidades de baixa renda e pouca habilidade dos pais na conduçăo da educação. Um fator de risco apontado, comum a outras pesquisas: vizinhança com altos índices de violência. $O$ projeto trabalha as atitudes dos jovens frente à violéncia, buscando aumentar a percepçáo dos riscos e conseqüências da violéncia, afirmaçăo do orgulho da sua identidade racial, construçăo de modelos positivos (através do mentoring). Um componente diferencial do programa é oferecer emprego a estes jovens por um periodo de seis meses, incentivando as atitudes $\theta$ responsabilidades deles frente ao trabalho. 
Currie (2000), ao avaliar esses programas, considera que estes últimos săo os melhores e que realmente funcionam, visto que associam uma resposta à questōes imediatas de sobrevivência para essas famílias vulneráveis. Sabe-se que a perspectiva de estabilidade e obtenção de um trabalho que possa sustentar uma familia no futuro são fatores muito importantes para permitir que o jovem "desista" da violéncia.

Um aspecto apontado, é que um projeto de intervenção, isoladamente, não vai resolver todo o problema. Torna-se necessário que outras medidas, de âmbito social mais amplo, sejam realizadas, a fim de que os ganhos obtidos sejam, de fato, efetivos.

Chamam a atenção, entretanto, para o fato de que, para iniciar propostas de intervenção, é sempre muito importante ter bem definidos quais são os conceitos com que se vai trabalhar (Powell e col. 1996):

- Estratégia é uma atividade presumida para reduzir violência, como o treinamento de habilidades sociais ou mediaçāo dos pares;

- Intervenção é a aplicaçăo da estratégia num determinado local, tal como uma escola, uma localidade;

- Programa é a coordenação combinada de várias intervenções complementares;

- Projeto pode ser uma intervenção ou um programa.

Em relação à população-alvo, a quem serão dirigidas estas estratégias:

- Dirigidas diretamente aos indivíduos do grupo alvo;

- Dirigidas ao grupo de pessoas que estão em contato íntimo com o grupoalvo, tais como familia, grupo de amigos, vizinhos;

- Dirigidas ao grupo social ou organizaçőes no qual o grupo alvo freqüenta, tais como escola, clubes etc;

- Ações realizadas no campo social voltadas para aumentar as oportunidades econômicas, campanhas de educação amplas etc. 
É recomendável basear suas estratégias de prevenção em alguns modelos conceituais acerca do comportamento adolescente e agressão. Existem várias teorias, entre aquelas apontadas pelo CDC (Powell e col, 1996):

- Teoria do comportamento aprendido, que assume que a agressão e a violéncia são comportamentos aprendidos a partir da observação e modelação pelo comportamento dos outros. Pretende fornecer alternativas de comportamento e modelos com diferente comportamento.

- Resiliência enfatiza a capacidade de os indivíduos terem vidas saudáveis e produtivas a despeito das dificuldades do ambiente que as envolve. A presença de cuidado, adultos suportivos, de oportunidades para o envolvimento com atividades significativas pode ser um fator crítico para a construção da resiliência em pessoas jovens.

Estudo de Assis \& Souza (1999), que buscava compreender a gênese da delinqüência juvenil, discorre sobre algumas teorias, classificando-as em três niveis:

1. nivel estrutural: refere-se à preponderância dos fatores sociais nas causas da violência. Neste nivel encontram-se as teorias relacionadas à distância entre as oportunidades sociais e as reais condiçōes de alcançá-las, levando à delinqüência. Baseia-se na desorganização social existente nas estruturas e instituiçōes sociais, mas acentuada nas camadas de renda mais baixa. A principal crítica é que este tipo de compreensão encontra-se muito ligado ao determinismo $e$ positivismo, sendo uma transposição mecảnica das condições de pobreza como causa direta da delinqüência;

2. nivel sociopsicológico: refere-se ao controle da família, escola e demais instituiçóes responsáveis pelo adolescente. Neste grupo, 
estão aquelas que discutem a questão da auto-estima como ligada à delinqüência e também a influência dos pares ou grupo social com que o jovem convive como fator;

3. nível individual, inclui aspectos biológicos e psicológicos que predispõem, mas não determinam, o indivíduo a ações criminosas. Inclui as teorias segundo as quais os atributos da personalidade, tais como impulsividade, inabilidade em lidar com o outro, ausência de culpa ou remorso por seus atos, encontram-se relacionados aos delinqüentes.

O CDC (2000) elaborou um documento de orientação para as comunidades que desejarem implantar práticas para prevenção da violência. Entre as estratégias sugeridas nesse guia, uma delas é dar suporte para as familias, especialmente onde há jovens de alto risco, estimulando as habilidades de como lidar com seus filhos, dar limites etc. Isto pode se dar por meio de reuniōes com vários pais em escolas ou associaçōes comunitárias. Uma outra é a visita domiciliar, quando a equipe vai à casa das famílias com maior risco, para dar informações, suporte psicológico, cuidados de saúde e outros serviços que os pais necessitem em relaçăo à educaçăo efetiva dos filhos.

O chamado mentoring também é uma dessas estratégias. Consiste na presença de um adulto voluntário, atuando como um modelo positivo, que possa supervisionar e servir de guia para um jovem, sem realizar julgamentos. Tal proposta parte da compreensão de que a ausência de um modelo é apontada como fator de risco para comportamento agressivo entre jovens, uso de álcool e drogas, entre outras. No Brasil, esse modelo é uma das medidas socioeducativas previstas no Estatuto da Criança e do Adolescente (ECA), para menores infratores. Presume a necessidade de acompanhamento da vida social destes adolescentes. A cidade de Belo Horizonte implantou o programa de liberdade assistida e comemora que $72 \%$ dos adolescentes, que cumprem medidas sócio-educativas determinadas pelo Juizado da Infância e Juventude da capital mineira, não retornaram ao 
crime, desde que o projeto foi implantado em 1997. Os orientadores são voluntários e "cuidam" dos menores por um periodo de seis meses. Os relatos desses voluntários e do pessoal do Juizado são que os resultados são gratificantes para ambos os lados ${ }^{15}$.

Porém, qualquer proposta de intervenção deve se dar a partir da compreensão de qual o problema principal que está ocorrendo numa determinada região. Programas de resolução de conflitos podem não ser a melhor escolha se o problema principal for, por exemplo, o envolvimento de jovens com o crime organizado. Alternativas voltadas para afastar estes jovens do mundo delinqüente podem ter mais êxito. Neste aspecto, se fosse possivel envolver outros setores que pudessem disponibilizar alguns postos de trabalho, com certeza seria muito bom, especialmente em comunidades pobres como a brasileira. Programas recreacionais que ocupem o horário livre dos jovens, estratégias para reforçar a auto-estima ou mesmo o mentoring podem funcionar.

\footnotetext{
${ }^{15}$ Jornal Folha de São Paulo, 21/06/01, Caderno Cotidiano.
} 
5. Considerações finais 
O crime em São Paulo adquiriu tal centralidade na vida cotidiana que redefine diariamente o comportamento da sua população. Mas, por que o novo século se inicia com a violência em tais proporçōes? Infelizmente, esta resposta provavelmente não existe. Como já foi discutido, não é resultado de um único processo social, podendo ser apontados diversos fatores: culturais, individuais, da organização das relaçōes sociais e familiares, da ocupação do espaço urbano, da existência de profunda e injusta desigualdade social.

Além de tudo isso, é preciso levar em conta também o processo de globalização, que trouxe profundas mudanças no sistema capitalista mundial - organização mundial da produção econômica, aceitação generalizada de certos valores (como direitos humanos e meio ambiente) e instantaneidade do acesso à informação. Tudo tem se transformado rapidamente, trazendo reflexos em todos os campos da sociedade. Essas transformaçōes passam pela estrutura de empregos, desagregação dos laços sociais, culturais e familiares, entre outras, que produziram uma corrosão das referências e estilos de vida e se aceleraram no sistema capitalista na década de 70 .

E não somente a economia se globalizou, mas também o crime. A expansão dos cartéis de drogas e armas não teria sido possivel sem as facilidades com que bilhões de dólares hoje podem circular no mundo, através de um mercado financeiro internacional. Noto \& Galduróz (1999) citam que, para o Drug Enforcement Administration, o Brasil é atualmente a principal rota de tráfico de cocaína na América Latina. Vários dos estudos de Zaluar (1984 e 1998), para a cidade do Rio de Janeiro, procuram destacar que o crescimento das taxas de criminalidade urbana violenta se dá às voltas do crime organizado, especialmente aquele voltado ao tráfico de drogas e de armas. Para esta autora, neste novo cenário, o crime gira em torno de um mundo, onde a linguagem corrente é a violência; onde impera a lei do mais forte, a valorização da coragem e do individualismo, onde a arma de fogo se torna objeto de prestígio e distinção.

Por outro lado, toda e qualquer análise sobre o tema deve ser feita conjugando-se os fatores externos com os fatores internos de cada pais, pois 
nem todos os paises pobres experimentaram aumento das taxas de criminalidade, da mesma forma que entre os paises ricos.

São muito diversos os fatores que estão relacionados com os homicidios. Portanto, um possível caminho é identificar, cada vez mais detalhadamente, as características particulares à realidade brasileira, ou paulista, ou daquele local específico onde se quer atuar. Isto porque o que concorre para a alta mortalidade por homicidios em São Paulo provavelmente é diferente de Alagoas ou Roraima. E mais ainda, a região central da cidade deve apresentar diferenças em relação às mortes ocorridas na zona sul. Foi isto que esse trabalho buscou fazer, entendendo ser esta uma abordagem inicial e, por isso, ainda superficial. O caminho é longo e ainda está por percorrer.

É preciso assinalar também que, graças ao capitalismo globalizado, "idealizou-se em escala quase mundial o lucro como valor supremo e o consumo como fonte mágica de superação de dores e angústias em direção ao prazer e à felicidade. Ao mesmo tempo, essa ideologia do lucro a qualquer preço é o que está na base das organizações mafiosas e cartéis do crime, no desvio de dinheiro por políticos sem escrúpulos, corrupção de policiais ou mesmo na ação de gangues que matam vítimas para satisfazer o desejo de comprar um tênis, drogas ou qualquer outra coisa que possa ser adquirida no primeiro shopping center" (Costa MR, 1999). O desejo de consumir e não aceitar limites para a satisfação de qualquer tipo de prazer são características muito atuais. Por isso, o horizonte imediato de algumas dessas violências é conseguir dinheiro rápido para consumir tudo o que for possivel (Adorno, 1999). E, se tal traço encontra-se inserido em um fenômeno mundial, para Costa JF (1999), citado por Costa MR (p.10, 1999), este processo atingiu uma perversidade particular em nosso pais, onde estaríamos imersos em uma cultura da delinqüência.

Diante da necessidade de se estabelecerem politicas públicas bem fundamentadas para o enfrentamento do problema, este trabalho buscou: 1) fazer uma análise da situação dos homicídios no Município de São Paulo ano 2.000, a partir dos dados dos registros oficiais; 2) fornecer subsídios para a 
vigilância dos homicídios neste municipio e 3) discutir alguns marcos teóricos referenciais sobre o problema.

A partir dos dados aqui apresentados, considera-se urgente a implantação de um Sistema de Vigilância Epidemiológica para os Homicídios. Para a Saúde Pública, advirão inúmeros ganhos a partir deste sistema, tais como o melhor planejamento e direcionamento dos recursos atualmente gastos com esses agravos e, principalmente, a contribuição para o estabelecimento de medidas concretas e viáveis para a reversão desse quadro. Ao lado disso, cabe ressaltar que, a partir de sua implementação, serão identificadas, cada vez mais, as "lacunas" do conhecimento e, portanto, as necessidades de pesquisas científicas, visando identificar grupos de risco e aperfeiçoar as bases técnicas para as medidas de prevenção e controle.

Mas há ainda outros desdobramentos, que merecem ser apontados, tais como: todos os dados processados no Sistema serão disponibilizados imediatamente para as outras Secretarias envolvidas, permitindo a uniformidade dessas informações, o que atualmente não ocorre.

Adicionalmente, a possibilidade do desenvolvimento de propostas de ações integradas entre diferentes Secretarias de Governo, com o envolvimento das Universidades e organizações da comunidade na discussão de propostas na área da violência, o que, conseqüentemente, traria grande enriquecimento e solidez a qualquer ação que viesse a ser implantada.

Considera-se, também, que as variáveis selecionadas permitem uma grande variedade de outros importantes cruzamentos que não foram possiveis de ser realizados em virtude do estudo ter abrangido somente três meses, principalmente os que envolviam a distribuição espacial, visto que são 96 distritos, o que acarreta dispersão desses números mais que o desejado. Desse modo, a implementação de um sistema de vigilância permanente pode trazer ainda muitos mais dados sobre o problema dos homicídios. 
Em relação à qualidade das informações registradas nas diferentes fontes, sabe-se que o atestado de óbito ainda deixa um pouco a desejar, sendo suas limitações bastante discutidas e conhecidas; porém, um dos desdobramentos do estabelecimento de um sistema de vigilância ativo seria a possibilidade da imediata correção desses dados, com visitas semanais ao IML para esclarecimento de imprecisões detectadas na DO. Além disso, tanto os telex para remoção do corpo quanto o próprio Boletim de Ocorrência também poderiam ser padronizados, de modo que viessem a fornecer melhores informações para um sistema que servirá a todos.

Em resumo, entende-se que a contribuição da Saúde Pública deva ser:

1. enfatizar a prevenção da violência antes que ela ocorra;

2. fazer ciência integral e continuamente de modo a identificar políticas e programas que possam ser efetivos;

3. promover a integração dos esforços das diversas disciplinas, instituições, organizações e comunidade.

$E$, além disso, para Saúde Pública, com o desenvolvimento deste sistema, experimenta-se trabalhar com a Epidemiologia e a Vigilância Epidemiológica de uma forma nova, em nosso país. Pois, trabalhar com um agravo desta natureza, que não é uma doença infecciosa; não é, tampouco, uma doença crônica e que tem os seus fatores determinantes ligados, principalmente, ao modo de vida da sociedade atual, vem tornar a implantação desta vigilância um estimulante, necessário e inadiável desafio. 
6. Conctusões 
As principais conclusões deste estudo referem-se a:

\section{Perfil da vitima}

$\checkmark$ O coeficiente de mortalidade por homicidios encontrado para o Município de S. Paulo, no ano de 2000 foi de 57,3/100.000 habitantes.

$\checkmark$ A maioria das vitimas pertence ao sexo masculino, visto que esta representou $92,5 \%$ do total, com coeficiente de $111,1 / 100.000$ homens. $O$ sexo feminino participou com $8,2 \%$ destas mortes, cujo coeficiente foi de $8,2 / 100.000$ mulheres. O coeficiente masculino é $1.285 \%$ maior que o feminino.

$\checkmark$ As vítimas são jovens em sua maioria, pois as idades de 15 a 29 anos concentraram $61,4 \%$ do total, exibindo também os maiores coeficientes. $O$ pico de idade, tanto para os homens quanto para as mulheres, se deu na faixa de 20 a 24 anos. Entre os primeiros, o coeficiente atingiu $286,4 / 100.000$. Para o sexo feminino, a taxa é 16,0/100.000.

$\checkmark$ As armas de fogo produziram $90,1 \%$ das mortes ocorridas no periodo analisado.

$\checkmark$ O álcool foi a substância psicoativa mais utilizada entre as vítimas, que tiveram o exame toxicológico realizado no IML, para os óbitos ocorridos nos meses de abril a junho de 2000. O seu uso isolado respondeu por $38,3 \%$ dos exames. O uso desta substância apresentou proporções diferentes quanto ao sexo (é maior entre os homens), o meio utilizado para a perpretação dos homicídios (é maior para os outros meios, que não armas de fogo) e ao tipo de local onde ocorreu o evento (chega a $78 \%$ para as vítimas que encontravam-se em bares). 
$\checkmark$ Em relação à localização anatômica da lesão, a cabeça foi o alvo mais freqüente $(29,9 \%)$, seguida do tórax $(20 \%)$.

\section{Circunstâncias do evento}

$\checkmark$ A avaliação da assistência médica às vitimas verificou que a possibilidade de atendimento pode ter existido para $57,6 \%$ delas, visto que as vítimas faleceram no Pronto-Socorro ou no caminho para este. $O$ percentual de pacientes internados é mínimo $(2,5 \%)$. O BO foi a melhor fonte para a obtenção deste dado, uma vez que essa informação foi anotada em $96,3 \%$ deles.

$\checkmark$ É na via pública que ocorre a maioria dos eventos $(68,8 \%)$, ficando em segundo lugar as residências, com $9,9 \%$, seguidas dos estabelecimentos comerciais $(4,7 \%)$ e bares, com $4,3 \%$.

$\checkmark$ Em relação ao dia da semana em que ocorrem os eventos, são os finais de semana que concentram a maioria deles - domingos e sábados. Em relação aos horários maior freqüência foi verificada entre 20 h00 e 24 h00 horas. Quando são analisadas estas informações em conjunto os horários de maior concentração de eventos são a sexta e sábado a partir das 20 h00 horas e a madrugada de domingo.

$\checkmark$ Quanto à motivação dos crimes, esta foi identificada para somente $24,9 \%$, a partir da análise dos BOs. O maior percentual foi classificado como conflitos interpessoais $(29,6 \%)$. Seguem-se os latrocínios, com $23,2 \%$ e as execuções, com $16,5 \%$. A motivação encontrada nos inquéritos policiais encerrados, cuja investigação tinha sido encaminhada à Delegacia de Homicídios e Proteção à Pessoa (DHPP), é bastante 
diversa. O percentual de motivação conhecido foi $27 \%$. Os crimes relacionados ao uso e tráfico de drogas chegam a $41,0 \%$. Esta diferença provavelmente está ligada à motivação identificada já no momento do crime e o outro após investigação, certamente os latrocínios, desavenças e crimes passionais podem ter a motivação estabelecida com maior rapidez do que os crimes ligados ao narcotráfico.

$\checkmark$ Os dados apontam a profunda desigualdade na distribuição espacial do risco para mortes por homicídios, com as maiores taxas sendo observadas nos distritos periféricos. O Jardim Paulista obteve o menor coeficiente de mortalidade por homicídios (3,6/100.000). No extremo oposto, encontra-se o distrito de Parelheiros, com coeficiente 28,5 vezes maior que o primeiro, atingindo 106,3/100.000 habitantes.

$\checkmark$ A maior parte dos locais com indicadores socioeconômicos mais desfavoráveis também apresenta maior risco para homicídios. Foi observada correlação positiva entre o coeficiente de mortalidade por homicidios segundo local de residência e indice de ocorrência e também para a mortalidade infantil. A correlação foi negativa para o nivel de renda e o indice de exclusão/inclusão social.

Vitimas e agressores - inquéritos policiais

$\checkmark$ Em relação ao perfil das vítimas, dos inquéritos encerrados, investigados no DHPP, a maioria das vítimas pertence ao sexo masculino e de jovens: a faixa de 20 a 24 anos concentrou $61,4 \%$ ( moda: 20 anos). Metade foi classificada como brancos (50\%), seguidos dos pardos $(34,1 \%)$ e negros $(11,6 \%)$, naturais de S.Paulo $(53,4 \%)$ e solteiros (57,6\%). Encontravam-se desempregados no momento do evento: $51,7 \%$. Possuíam baixa instrução, pois $40,1 \%$ não haviam completado o ensino 
fundamental; os analfabetos somaram $4,2 \%$. Entre aqueles considerados usuários de substâncias psicoativas, $42,5 \%$ faziam uso de álcool. A maconha foi a segunda droga mais utilizada, $22,1 \%$, seguida do crack, $11,7 \%$. Foi identificada situação de conflito com a lei em $31,5 \%$ das vitimas.

$\checkmark$ No grupo dos agressores, os homens também predominam (98,9\%). São um pouco mais jovens que as vítimas: a faixa que apresentou a maior freqüência foi de 15 a 19 anos (28,7\%). São brancos, em sua maioria $(45,7 \%)$, seguidos dos pardos $(36,2 \%)$ e depois dos negros $(9,6 \%)$. A maior parte era de solteiros $(60,6 \%)$. Neste grupo, cresce o número de analfabetos que chega a $10,6 \% ; 38,3 \%$ tem o ensino fundamental incompleto. Sobe para $41,5 \%$ a proporção daqueles que possuiam antecedentes criminais. Em relação ao uso de drogas, esta informação é ignorada para $53,2 \%$ dos casos, mas um pouco menos que a metade $(41,5 \%)$ declararam-se usuários. Entre estes, é a maconha que ocupa o primeiro lugar $(30,6 \%)$, seguindo-se, o álcool, com $25 \%$. Foi possivel observar semelhanças entre as características das vítimas e agressores. Este último grupo apresentou percentuais mais desfavoráveis quanto a escolaridade, antecedentes criminais e uso de substâncias psicoativas.

\section{Vigilância epidemiológica}

$\checkmark$ Em relação à vigilância epidemiológica, o modelo proposto para a monitorização da mortalidade por homicídios com base na reunião caso a caso, das informações provenientes das três principais fontes de dados sobre homicidios, demonstrou que amplia o número de informaçōes e para algumas variáveis agrega maior qualidade. 
$\checkmark$ Um sistema ativo cumpre melhor os propósitos de uma vigilância para homicídios no Município de São Paulo, devido à maior sensibilidade, representatividade e agilidade para sua implantação.

$\checkmark$ Em relação à escolha das fontes considerou-se que a DO deve se constituir na base de dados, cujas informações devem ser completadas com laudos de necropsia e BO. 
7. Referências 
Abdetran - Associação Brasileira dos Departamentos de Tránsito 1997. Impacto do uso de álcool $\theta$ outras vitimas de acidentes de tránsito. Cetad\&Raid, 87 pp.

Adorno S, Bordini EBT, Lima RS. O adolescente e as mudanças na criminalidade urbana. Sáo Paulo em Perspec 1999; 13 (4): 62-74.

Akerman M \& Bousquat A. Mapas de risco de violência. Såo Paulo em Perspec 1999; 13 (4): 62-74.

American Medical Association. Council on Scientific Affairs. Assault weapons as a public health hazard in the United States. JAMA 1992, $267: 3067-70$.

APM - Associação Paulista de Medicina. Violência atinge médicos em São Paulo. Jomal da APM agosto 2001; 515: 13.

Assis SG \& Souza ER. Criando Caim e Abel - pensando a prevenção da infração juvenil. Cienc Saúde Coletiva 1999, 4 (1):131-144.

Barata RB, Ribeiro MC, Guedes MB, De Moraes, JC. Intra-urban differentials in death rates from homicide in the city of Sazo Paulo, Brazil, 1988-1994. Soc Sci Med Jul 1998; 47(1) : 19-23.

Bastos Fl e Carlin-Cotrim B. CNPD - Comissão Nacional de População e Desenvolvimento. Jovens acontecendo na trilha das políticas públicas. Vol 2, 645665. Brasilia, maio de 1998.

Bercovich F, Madeira FR, Torres HG. Descontinuidades demográficas. O futuro pede passagem. 20 anos no Ano 2000 - Estudos sócio-demográficos sobre a juventude paulista 1998; 2-12.

Bormann Ca, Stone MH. The effects of eliminating alcohol in a college stadium: the Folsom Field beer ban. J Am Coll Health 2001 Sep; 50(2):81-8.

Brasil, Leis, etc. Estatuto da Criança e do adolescente: Lei 8069 de 13.07.90. SITRAEMFA, Brasilia, 1990.

Brasil. Ministério da Saúde. Política nacional de redução da morbimortalidade por acidentes e violências: Portaria MSIGM no. 737 de 16/05/01 publicada no DOU no. 96 seção 1E, de 18/05/01/ Ministério da Saúde - Brasília: Ministério da Saúde, 2001.

Caetano R, Cunradi CB, Clark CL, Schaffer J. Intimate partner violence and drinking pattems among white, black and hispanic couples in the U.S. J Subst Abuse 2000; $11(2): 123-38$.

Camargo ABM. Mortalidade por causas externas no Estado de Såo Paulo e suas regiōes. Sāo Paulo, 2002. [Tese de Doutoramento - Faculdade de Saúde Pública da USPI

Carvalho CG. Álcool em vítimas de causas extemas. São Paulo, 2002. Trabalho de qualificação apresentado à Faculdade de Medicina da Universidade de São Paulo para a obetnçăo do título de Doutor em Medicina. 
CDC, Centers for Diseases Control and Prevention. Best practices of youth violence prevention - A sourcebook for community action. Atlanta, Georgia, September, 2000.

CEBEPEJ - Centro Brasileiro de Estudos e Pesquisas Judiciais. Perfil do réu nos delitos contra o patrimônio (furto e roubo)- Série pesquisa, 2000.

CET - Companhia de Engenharia de Tráfego - Fatos e estatísticas de acidentes de trânsito em São Paulo - 2001.

Chesnais JC. A violência no Brasil. Causas e recomendaçōes politicas para a sua prevenção. Ciênc Saúde Coletiva 1999; 4 (1):53-69.

CNPD - Comissão Nacional de População e Desenvolvimento. Jovens acontecendo na trilha das politicas públicas. Brasília, maio de 1998.

Colégio Brasileiro de Cirurgióes, Sociedade Brasileira de Atendimento Integrado ao Traumatizado, Sociedade Brasileira de Ortopedia e Traumatologia, Conselho Federal e Ministério da Saúde. Relatório da Semana do Trauma, 1999.

Costa MR. A violência urbana é particularidade da sociedade brasileira? Săo Paulo em Perspec 1999; 13 (4): 3-12.

Costa JF. "Narcisismo em tempos sombrios". In: Fernandes, H.R. Tempo do desejo: sociologia e psicanálise. São Paulo, Brasiliense, 1989, p 109-136.

Currie E. Sociologic perspectives on juvenile violence. Child Adolesc Psychitr Clin N Am 2000 Oct;9(4):749-763.

Demetriades D. et al. Epidemiology of major trauma and trauma deaths in Los Angeles County. J Am Coll Surg Oct 1998; 187 (4) :373-83.

Deslandes SF. O atendimento às vítimas de violéncia na emergéncia: "prevenção numa hora dessas?". Ciênc Saúde Coletiva 1999, 4 (1):81-94.

DHPP- Delegacia de Homicídios e Proteção à Pessoa.. Anuário DHPP-1997 Polícia Civil do Estado de São Paulo - Divisão de Homicídios. 1998.

DHPP- Delegacia de Homicidios e Proteção à Pessoa.. Anuário DHPP-1998, Polícia Civil do Estado de São Paulo - Divisão de Homicídios. 1999.

Drumond Jr M \& Barros MBA. Desigualdades socioespaciais na mortalidade do adulto no Municipio de Săo Paulo. Rev.Bras.Epidemiol. 1999; 2 (1/2).

Elias N. O processo civilizador. formação do Estado e civilizaçăo. Rio de Janeiro, 1993, Jorge Zaluar Editor.

Falbo GH, Buzzetti R, Cattaneo AA. Homicide in children and adolescents: a casecontrol study in Recife, Brazil.Bulletim of the World Helath Organization, 79 (1): 1-7. Geneve, 2001.

Farington DP, Loeber R. Epidemiology of juvenile violence. Child Adolesc Psychiatr Clin N Am 200 Oct; 9(4):733-748. 
Farrell AD, Meyer AL, Dahlberg LL. Richmond youth against violence: a schoolbased program for urban adolescents. Am J Prov Med 1996; supplement to vol 12 (5): 13-21.

Frattaroli S \& Teret SP. Why firearm injury surveillance? Am J Prev Med 1998 Medicine, 15 (3S): 3-5, 1998.

FUNASA - Fundação Nacional de Saúde. htto:/humw.funasa.gov.br/epi/epioo.htm. 25/10/2001.

Gawryszewski VP. A mortalidade por causas externas no Municipio de São Paulo, 1991. São Paulo, 1995 [Dissertação de Mestrado - Faculdade de Saúde Pública da USP].

Gawryszewski VP. Uma proposta para vigilância epidemiológica dos homicidios em Såo Paulo, p.80. IV Congresso brasileiro de Epidemiologia, V.1, Rio de Janeiro (CC 55-185), 1998.

Gawryszewski VP \& Mello Jorge MHP - Mortalidade violenta no Município de São Paulo: um retrato dos últimos 40 anos. Rev.Bras. Epidemiol. 2000; 3 (1-3).

Graitcer PL. Injury surveillance. In: Halperin W \& Baker Jr EL. Public helath surveillance. New York, 1992. Van Nostrand Reinold, p. 142-156.

Guerrero R. In Violência en lãs Américas, una menaza a la integracion social (texto preparado para la Primera Conferencia Regional de Seguimiento de la Cumbre sobre Desarrollo Social. São Paulo, Brasil, 6-9 Abril, 1997.

Hammann EM, Laguardia, J. Reflexões sobre a Vigilância Epidemiológica: mais além da notificação compulsória. Informe Epidemiol6gico do SUS 2000; 9(3): 211219.

Harvard University. http://umw.cdc.gov./ncipc/res-opps/hatavrd.htm , 2001.

Hemenway D, Azrael D, Miller M. Gun use in the United States: results from two national surveys. Injury Prevention Dec 2000; 6(4) : 263-7.

Holder HD, Gruenevald PJ, Ponicki WR, Treno AJ, Grube JW, Saltz RRB, Reynolds R, Davis J, Sanchez L, Gaumont G, Roeper P. Effect of cmmuity-based interventions on high-risk drinking an alohol-related injuries. JAMA 200 Nov 8; 284 (18):2341-2347.

IBGE. http://umw.ibge.gov/brl. 2001. Indicadores sociais - Síntese dos indicadores sociais - Tabela 6.11.

IBGE. http://uww.ibge.gov/br/ibge/estatistica/populacao/censo2000. Janeiro/2002.

Ikeda RM, Gorwitz R, James SP, Powell KE, Mercy JA. Fatal Firearm Injuries in the United States 1962-1994 - Violence Surveillance Summary Series, № 3, CENTERS FOR DISEASES CONTROL. Atlanta, Georgia, 1997. 
ILANUD, Instituto Latino-Americano das Naçōes unidas para a Prevenção do Delito e o Tratamento do Delinqüente. "Pesquisa de Vitimizaçăo". Revista do llanud. São Paulo, $n^{\circ} 10,1998$.

lunes RF. Impacto econômico das causas externas no Brasil: esforço de mensuração. Rev. Saúde Pública 1997; 31 (4 suplemento): 38-46.

Kahn T. Os custos da violência - quanto se gasta ou deixa de ganhar por causa do crime no Estado de São Paulo. Såo Paulo em Perspec 1999; 13 (4): 42-48.

Kellermann AL, Bartolomeos KK. Firearm injury surveillance at the local level. From data to action. Am J Prev Med 1998; 15 (3s) : 109-112.

Kim NA \& Trent R. Firearm-related injury surveillance in California. Am J Prev Med 1998; 15 (3S): 31-37.

Kuo M, Mohler B, Raudenbush SL, Earls FJ. Assessing exposure to violence using multiple informants: application of hierarchical linear model. J. Child Psychol.

Psychiat 2000, 41 (8): 1049-1056.

Kyriacou DN, Hutson HR, Anglin D, Peek-Asa C, Kraus JF. The relationship between socioeconomic factors and gang violence in the City og Los Angeles. $J$ Trauma Feb 1999; 46(2) :334-9.

Laurenti R \& Mello Jorge MHP. O atestado de Óbito. Centro Colaborador da Organização Mundial da Saúde para a Classificação de Doenças em Português, São Paulo, 1995. Série divulgação no 1 - 1996.

Lebrāo ML, Mello Jorge MHP, Laurenti R. Ver Saúde Pública 1997; 31 (4 Suplemento):26-37.

Lima RS, Conflitos sociais e criminalidade urbana: uma análise dos homicidios cometidos no Municipio de Sảo Paulo, 2000. [Dissertação de Mestrado - Faculdade de Filosofia, letras e Ciências Humanas da USP]

Logan TK, Leukefeld C, Walker B. Violence Vict. Spring, 2.000; 15 (1):91-111.

MacDonalds S, Wells S, Giesbrecht N, Cherpitel CJ. Demographic and substance use factors related to violence and accidental injuries: results from na emergency room study. Drug Alcohol Depend, Jun 1999; 55 (1-2):53-61.

Madeira FR \& Mameri CP. O futuro pede passagem. 20 anos no Ano 2000 Estudos sociodemográficos sobre a juventude paulista. ix-x, 1998.

Madeira FR. Violência nas Escolas: Quando a vítima é o processo pedagógico. Săo Paulo em Perspec 1999; 13 (4): 47-61.

Mello Jorge MHP. Mortalidade por causas violentas no Municipio de Săo Paulo. Sazo Paulo, 1979. [Tese de Doutoramento - Faculdade de Saúde Pública da USP]

Mello Jorge MHP. Mortalidade por causas violentas no Município de São Paulo, Brasil. IV - A situação em 1980. Rev. Saúde Pública 1982; 16 :19-41. 
Mello Jorge MHP, Gawryszewski VP, Latorre MRDO. I - Análise dos dados de mortalidade. Rev. Saúde Pública 1997; 31 (4 suplemento): 5-25.

Mello Jorge MHP \& Yunes J. Violéncia e Saúde no Brasil. Trabalho encaminhado para publicaçăo, 2001.

Menéndez EL \& Pardo RB. Violência alcoholizadas y relaciones de género. Estereotipos y negaciones. Cuademos Médico Sociales 2001; no. 79,.

Mercy JA, Ikeda R, Powell KE. Firearm-Related Injury Surveillance - An Overview of Progress and Challenges Ahead. Am J Prev Med 1998; 15 (3S): 6-17.

Miller TR, Fisher DA, Cohen MA. Costs of Juvenile Violence: Policy Implications. Pediatrics January, 2001; 107(1).

Minayo MCS \& Souza ER. É possível prevenir a violência? Reflexōes a partir do campo da saúde pública. Ciénc Saúde Coletiva 1999; 4 (1):7-32.

MS - Ministério da Saúde. Rev Saúde Pública 2000; 34(4): 427-30.

MS - Ministério da Saúde. Secretaria de Assistência à Saúde. Sistema de Informaçōes em Saúde para Acidentes e Violências/ Causas Externas, 2002.

Noronha J. Violência - A epidemia do início do século. Ser médico. Publicação do Conselho Regional de Medicina do Estado de São Paulo, jan/fev/mar/2002 - Ano V - no. 18.

Noto AR \& Galduróz. O uso de drogas psicotrópicas e a prevenção no Brasil. Ciénc Saúdo Coletiva 1999; 4 (1):145-151.

Nunez S, Garcia-Martin P, Aguirre-Jaime A. Victims of violence in na emergency department. Eur J Emerg Mod 2000 Mar, 7(1):45-49.

OMS - Organização Mundial da Saúde. Classificação Estatistica Intemacional de Doenças e problemas Relacionados à Saúde - 10 Revisão. Centro Colaborador da Organização Mundial da saúde para a Classificaçāo de Doenças em Português, São Paulo, 1995.

OMS - Organização Mundial da Saúde. Classificação Internacional de Doenças: revisão 1975. Centro Colaborador da Organização Mundial da saúde para a Classificação de Doenças em Português, São Paulo, 1980.

OPS - Organización Panamericana de la Salud. Vigilancia epidemiológica de homicidios y suicidios. Bol. Oficina Sanit. Panam. 1996; 120 (4).

Pearce N. Tradional epidemiology, Modem Epidemiology, and Public Health. American Joumal of Public Health 1996; 86 (5) : 678-83.

Pillman F, Ulirich S, Draba S, Sannemuller U, Mameros A. Acute effects of alcohol and chronic alcoholism as cause of violent crime. Nevenarzt 2000; 71 (9) :715-21.

Powell KE et all. Prevention of Youth Violence: rationale and Characteristics of 15 Evaluation Projects. Am J Prev Mod 1996; supplement to vol 12 (5): 3-12. 
Ringwalt CL, Graham LA, Paschall MJ. Supporting adolescents with guidance and employment. Am J Prev Med 1996; vol12 (5).

RIPSA, Rede Interagencial de Informaçōes para a Saúde. muw.saude.gov.br, 2000.

Rodrigues EM, Souza GOC, Torres MHG; Godinho RE. Distribuição espacial. 20 anos no Ano 2000 - Estudos sócio-demográficos sobre a juventude paulista 1998; 14-33.

Rodriguez, Lasch KE, Chandra P, Lee J. J Epidemiol Community Health. \%\% (3) : 172-8, Mar, 2001.

Rolnik R. Exclusāo Territorial e Violència. Săo Paulo em Persp 1999; 13 (4): 10011.

Rosenberg ML \& Hammond WR. Surveillance the key to firearm injury prevention. Am J Prov Mod 1998; 15 (3S): 1.

Santos BS. Notas sobre a história jurídico social de Pasárgada. In: Maricato E. Metrópole na periferia do capitalismo: ilegalidade, desigualdade e violência. São Paulo: Hucitec. 1995.

Satcher D, Powell KE, Mercy JA, Rosemberg ML. Violence Prevention Is as American as Apple Pie. Am J Prev Med 1996; supplement to vol 12 (5), opening commentary.

SEMPLA - Secretaria Municipal do Planejamento. Săo Paulo: crise e mudança. S. Paulo, Editora Brasiliense, [1991].

SES - Secretaria de Estado e Saúde do Estado de Săo Paulo, URL mun.saude.sp.gov.br, 2000.

SES - Secretaria de Estado e Saúde do Estado de São Paulo. Boletim CIS/200 n 1. Mortalidade por causa externas julho/2000. Coordenadoria de Planejamento e Saúde-CPS /Grupo Técnico de Informaçōes de Saúde-CIS

Silveira RMJ. Atestado Médico Falso. Centro Colaborador da Organização Mundial da saúde para a Classificação de Doenças em Português, Sảo Paulo, 1995. Série divulgaçăo n 9 - 1996.

Souza ER. Homicídios no Brasil: o grande vilão da Saúde Pública na década de 80. Cad. Saúde Públ. 1994; 10 (supl 1):45-60.

Sposati A. Mapa da exclusăo/inclusăo social da cidade de Sáo Paulo/2000. Dinâmica social dos anos 90. CD-Rom.

Szwarcwald CL, Bastos FI, Esteves MAP, Andrade CLT, Paez MS, Medici EV, Derrico M. Desigualdade de renda e situação de saúde: o caso do Rio de Janeiro. Cad. Saúde Pública, Rio de Janeiro, 15(1): 15-28, jan-mar, 1999. 
Szwarcwald CL \& Leal MC. Sobrevivência ameaçada dos jovens brasileiros: a dimensåo da mortalidade por armas de fogo. CNPD Jovens acontecendo na tritha das políticas públicas. Brasília, maio de 1998; 1: 363-393.

Triola MF. Introduçăo à Estatistica - sétima edição. Livros Técnicos e Científicos Editora S.A. Rio de Janeiro, 1998.

United Nations. Demographic yearbook-1998. New York, 1999.

Waldman EA. Vigilância em Saúde Pública, volume 7. Faculdade de Saúde Pública da Universidade de São Paulo, 1998 (Série Saúde \& Cidadania)

Waldman EA, Mello Jorge MHP. Vigilância para acidentes e violéncias: instrumento para estratégias de prevenção e controle. Ciênc Saúde Coletiva 1999, 4 (1):71-79.

WHO - World Health Organization. Injury Surveillance Guidelines for LessResourced Environments. 02/2001.

Wieviorka M. O novo paradigma da Violência. Tempo Social: Rev. Sociol. USP. São Paulo 1997. 9 (1):5-41.

Wilt SA \& Gabrel CS. A weapon-related injury surveillance system in New York City. Am J Prov Mod 1998; 15 (3S): 75-82.

Yunes J. Mortalidad por causas violentas en la región de las Américas. Bol Oficina Sanit. Panam. 1993; $114: 303-15$.

Yunes J \& Zubarev T. Mortalidad por causas violentas en adolescentes y jóvenes: un desafio para la la región de las Américas. Rev. Bras. Epidemiologia 1999; 2 (3).

Yunes J. Epidemiologia da violência. In Oliveira MC. Demografia da exclusão social: temas $\theta$ abordagens. Ed. Unicamp, 2001.

Zaluar A, Noronha JC, Albuquerque C. Violência: pobreza ou fraqueza institucional? Cad. Saúde Pública 1994; 10 (supl.1) : 213-7.

Zaluar A. Condomínio do Diabo. Rio de Janeiro, Revan e UFRJ, 1994.

Zaluar A. Para năo dizer que não falei de samba: os enigmas da violência no Brasil. In: SCHWARCZ, I. (org) História da vida privada no Brasil: contrastes da intimidade contemporanea. Săo Paulo, 1998. Companhia das Letras. 